\title{
A Comparison of Analytical Methods for Quantifying Denatured Whey Proteins and Their Correlation to Solubility
}

\author{
A Thesis Presented to the \\ Faculty of California Polytechnic State University, \\ San Luis Obispo
}

In Partial Fulfillment

of the Requirements for the Degree

Master of Science in Agriculture, with a Specialization in:

Dairy Products Technology

by

Michelle Doreen Allen 
(C) 2010

Michelle Doreen Allen

ALL RIGHTS RESERVED 


\section{Committee Membership}

TITLE:

AUTHOR:

DATE SUBMITTED:

COMMITTEE CHAIR:

COMMITTEE MEMBER:

COMMITTEE MEMBER:
A Comparison of Analytical Methods for Quantifying Denatured Whey Proteins and Their Correlation to Solubility

Michelle D. Allen

July 7, 2010

Dr. Phillip S. Tong

Director and Professor

Dairy Products Technology Center

Dairy Science Department

Dr. Margaret Rice

Professor

Chemistry and Biochemistry Department

Dr. Amy Lammert

Assistant Professor

Dairy Products Technology Center

Dairy Science Department 


\begin{abstract}
A Comparison of Analytical Methods for Quantifying Denatured Whey Proteins and
\end{abstract}

Their Correlation to Solubility

\title{
Michelle Doreen Allen
}

Protein structure affects the bioactivity and functionality of whey protein ingredients in food systems. Bioactivity of whey proteins and their derivatives are highly dependent upon primary, secondary and tertiary structure. The degree of denaturation of whey proteins is an important factor for determining how whey protein ingredients will perform in a food system. Several analytical methods have been developed to quantify protein denaturation of whey proteins. The goal of this project was to use a variety of analytical methods to quantify whey protein denaturation and to evaluate the correlation of denaturation to the functionality of whey protein powders.

The objective of the first series of experiments was to compare three different analytical methods to measure denaturation of whey proteins in liquid whey obtained by various methods of separation and with varying degrees of heat treatment. A split plot experimental design was used. Raw bovine milk was skimmed and liquid whey was separated from the skim milk at natural $\mathrm{pH}$. Three separation methods: 1) centrifugation, 2) membrane filtration and 3) enzyme coagulation, made up the first split plot. Each subplot of liquid whey was then divided into three split plots to receive heat treatment. Heat treatments were no heat, $76^{\circ} \mathrm{C}$ for fifteen seconds and $85^{\circ} \mathrm{C}$ for three minutes. Each of the resulting nine treatment combinations was analyzed by 1) polyacrylamide gel electrophoresis, 2) bicinchoninic acid-soluble protein assay and 3) fluorescence spectroscopy to determine the amount of denatured protein in the liquid whey.

Fluorescence spectroscopy was found to be the most sensitive and reliable method 
for detecting differences in structure due to denaturation, while native polyacrylamide gel electrophoresis was found to be the least sensitive method. The sample which received the centrifugal treatment of isolation with no heat was found to be the most undenatured in structure while the sample which received the enzyme treatment of isolation with high heat was found to be the most denatured in structure.

The objective of the second series of experiments was to evaluate the effect of denaturation on whey protein solubility in dried whey protein powders. Solubility is one of the most important functional properties to consider when selecting a whey protein ingredient, especially for beverage systems. Processing parameters are often manipulated in efforts to improve solubility. The protein structures of whey are considered to have an effect on solubility. Specifically, the degree of denaturation of whey proteins is thought to play a role in solubility.

In this experimental design, raw bovine milk was skimmed and pasteurized then enzyme-coagulated at natural $\mathrm{pH}$ to separate the whey. Liquid whey was then split into three aliquots and each received one of the following treatments: 1) mild heat/ freeze dry, 2) mild heat/spray dry and 3) high heat/spray dry. Heat treatment was applied to liquid whey prior to concentration. Heat treated whey was then concentrated and dried. Powders were reconstituted and analyzed for denaturation using 1) bicinchoninic acid assay for soluble protein and 2) fluorescence spectroscopy and for solubility using an insolubility index.

pH 4.6 solubility and fluorescence spectroscopy for quantifying denaturation correlated well to one another. Both found that the low heat treated samples were less denatured in structure than the sample which received the high heat treatment, regardless 
of drying method. However, the drying method of the protein powders was correlated to solubility rather than heat treatment. A correlation of denaturation measured in whey protein powders and solubility was apparent for the low heat, freeze dried sample and the high heat, spray dried sample.

Several conclusions were made in this research. 1) Centrifugal force causes less denaturation than membrane filtration and enzyme coagulation, thus unheated liquid whey obtained by centrifugal force can be used as a control in research on denaturation. 1) Fluorescence spectroscopy is a better method for quantifying denaturation in liquid and powdered whey compared to native PAGE and $\mathrm{pH} 4.6$ solubility measured by BCA. 3) Functional solubility is dependent on denaturation and can be correlated to analytical methods of measuring denaturation. 


\section{Acknowledgements}

First, I would like to thank my committee- Dr. Phillip S. Tong, committee chair, for his support and advice during my research and guidance throughout my pursuit of my Master's of Science degree; Dr. Margaret Rice and Dr. Amy Lammert, committee members, for their guidance and advice in their areas of expertise as well as their overall support.

I would also like to acknowledge and thank several other faculty and staff of Cal Poly- Dr. Karen McGaughey, Department of Statistics, for her advice and assistance for the statistical designs and analyses of experiments for all components of this research, Rich Silacci, Dairy Herdsman, and Sean Vink, Dairy Products Technology Center, for their technical support and assistance.

The support and friendship of the entire faculty, staff and my graduate student peers at the Dairy Product Technology Center are greatly appreciated.

I would also like to thank all of my family and friends for supporting me in this endeavor, especially my husband, Dave, and my parents, Mike and Linda, for their continuous moral support in whatever I do.

Finally, I would like to thank the California Dairy Research Foundation and Dairy Management, Inc. for the financial support of this research. 
List of Tables

List of Tables xiii

List of Figures xiv

1.0 Introduction 1

2.0 Literature Review 3

2.1 Whey Protein as a Food Ingredient 3

2.1.1. Commercially Available Forms of Whey Protein 3

2.1.2. Whey Protein Powder Manufacture 3

2.1.3. Functional and Nutritional Properties 6

2.1.4. Native Versus Cheese Whey Powders 14

2.1.5. Nutrition 16

2.1.6. Bioactivity of Whey Protein 19

2.2 Whey Protein Chemistry 21

2.2.1. Whey Proteins Defined 21

2.2.2. Alpha-lactalbumin ( $\alpha$-la) 22

2.2.3. Beta-lactoglobulin $(\beta-\lg )$ 23

2.2.4. Bovine Serum Albumin (BSA) 25

2.2.5. Immunoglobulin (Ig) 26

2.2.6. Other Whey Proteins 26 
2.3.1. Structural Changes and Relationship to Functional Properties

2.4.1. Temperature and $\mathrm{pH}$ 32

2.4.2. Shear 35

2.5 Analytical Methods of Characterizing Whey Protein Denaturation 37

2.6 Justification of research 48

2.6.1. Significance of Research to Dairy Industry 50

2.6.2. Research Hypotheses and Objectives 51

3.0 Materials and Methods 53

3.1 Experiment 1 53

3.1.1. Skim, Raw Milk 54

3.1.2. Enzyme Isolation 55

3.1.3. Membrane Filtration 55

3.1.4. Centrifugal Isolation 56

3.1.5. Heat Treatment 56

3.1.6. Native PAGE 57

3.1.7. Fluorescence Spectroscopy 58

3.1.8. BCA 59

3.1.9. Statistical Analysis 60 60 
3.2.1. Whey Manufacture 62

3.2.2. Heat Treatment 63

3.2.3. Powder Manufacture 63

3.2.4. Solubility 65

3.2.5. Fluorescence Spectroscopy 66

3.2.6. BCA 66

3.2.7. Statistical Analysis 67

4.0 Results and Discussion 68

4.1 Preliminary Research 68

4.1.1. Experiment 1 68

4.1.1.1. Factors of Experiment 1 68

4.1.1.2. Responses of Experiment 1 70

4.1.2. Materials and Methods of Method Development for Experiment 1 70

4.1.2.1. Manufacture of Liquid Whey 70

4.1.2.2. Heat Treatment 71

4.1.2.3. Analytical Quantification of Whey Protein Denaturation 71

4.1.3. Materials and Methods of Method Development for Experiment 2 73

4.2 Experiment 1 76

4.2.1. Characterization of Native Whey Protein 76

4.2.2. Denaturation Characterized by Native PAGE in Whey 78

4.2.3. Denaturation Characterized by Fluorescence Spectroscopy in Whey 81 
4.2.4. Denaturation Characterized by BCA in Whey

4.2.5. Effects of Experimental Factors on Denaturation in Whey 86

4.2.5.1. Effect of Heat Treatment 86

4.2.5.2. Effect of Isolation Method 88

4.3 Experiment 2 89

4.3.1. Denaturation in Whey Powder 89

4.3.1.1. Effect of Treatment 90

4.3.1.2. Denaturation Characterized by Fluorescence Spectroscopy in Whey

Powder 90

4.3.1.3. Denaturation Characterized by Bicinchonic Acid Asay in Whey

Powder 91

4.3.2. Solubility of Whey Protein Powders 91

4.3.3. Relationship between Solubility Results and Denaturation Results 94

4.4 Significance of Research for Scientific Community and Dairy Industry 94

5.0 Conclusion and Future Research 97

5.1 Conclusion 97

5.2 Limitations of Research 98

5.3 Future Research 99

References 100

Appendices 111

Appendix 1: Statistical Analysis for Experiment 1 (SAS) 111

Appendix 2: Statistical Analysis for Experiment 2 (Minitab) 123 
Appendix 3: Native PAGE Gels

Appendix 4: List of Acronyms 


\section{List of Tables}

$\underline{\text { Table }}$

$\underline{\text { Page }}$

Table 2.1 Typical Composition and Applications of Whey Protein Products 3

Table 2.2 Functional Uses of Whey Protein 7

Table 2.3 Nutritional Qualities of Common Food Proteins 18

Table 2.4 Highlights of Bioactivity of Whey Protein Derivatives 21

Table 2.5 Time-Temperature Relationships for Pasteurization___ Error! Bookmark not defined.Error! Bookmark not defined.

Table 2.6 Common Methods for Measuring Whey Protein Denaturation 50

Table 3.1 Statistical Design of Experiment 1 53

Table 3.2 Statistical Analysis of Experiment 1 60

Table 3.3 Design of Experiment: Experiment 2 61

Table 3.4 Statistical Analysis of Experiment 2 67

Table 4.1Exerimental Design by Response for Experiment 1 69

Table 4.2 Experimental Design by Response for Experiment 2 74

Table 4.3 Statistical Differences for Interaction Effects by Fluorescence Spectroscopy 


\section{List of Figures}

Figure $\quad$ Page

Figure 2.1 Flow Diagram of Whey Protein Powder Manufacture ___ 4

Figure 2.2 Secondary Structure of Alpha-lactalbumin __ 23

Figure 2.3 Secondary Structure of Beta-lactoglobulin __ 24

Figure 3.1 Design of Experiment 1__ 54

Figure 3.2 Membrane Filtration Schematic __ 56

Figure 3.3 Flow Diagram for Experiment $2 \ldots 62$

Figure 3.4 Schematic of Whey Manufacture __ 63

Figure 3.5 Schematic for Whey Powder Manufacture ___ 65

Figure 3.6 Solubility Procedure __ 66

Figure 4.1 Peak Fluorescence Intensities by Treatment __ 78

Figure 4.2 Densities of Whey Proteins Bands by Isolation Method Measured by Native PAGE

Figure 4.3 Density of Whey Proteins Bands by Heat Treatment Measured by Native PAGE

Figure 4.4 Expected Trend for Response of Fluorescence Spectroscopy to Denaturation 281

Figure 4.5 Peak Intensity of Whey Proteins by Isolation Method Measured by Fluorescence Spectroscopy __ 82

Figure 4.6 Peak Intensity of Whey Proteins by Heat Treatment Measured by Fluorescence Spectroscopy _ 82 
Figure 4.7 Expected Trend for Response of $\mathrm{pH} 4.6$ solubility measured by BCA to Denaturation __ 84

Figure 4.8 Soluble Protein by Isolation Method by BCA__ 85

Figure 4.9 Soluble Protein by Heat Treatment by BCA 85

Figure 4.10 Native PAGE gel ____ 87

Figure 4.11 Peak intensity of Treated Whey Protein Powder by Fluorescence Spectroscopy 90

Figure 4.12 Protein of Treated Whey Protein Powder by BCA ___ 91

Figure 4.13 Protein Insolubility due to Treatment __ 92

Figure 4.14 Whey Protein Solubility ___ 92 


\subsection{Introduction}

Whey is the liquid that is separated from the curd during cheese making. Liquid whey contains mostly water, lactose, minerals and small amounts of fat and protein. Protein in the whey has been found to be of great biological value in the human diet and provides an array of functionality in food systems. There are four classes of proteins in cow's milk, three of which end up in the whey in cheese making. Beta-lactoglobulin ( $\beta$ lg), alpha-lactalbumin ( $\alpha$-la) and serum albumin and several immunoglobulins are collectively known as the whey proteins. Casein makes up approximately seventy-five percent of protein in milk and coagulates with rennet to form a curd during cheese making.

The functional roles of whey proteins in food systems are solubility, viscosity, gelation, emulsification, foaming and nutrition. These functional roles have made whey proteins widely used as food ingredients. Whey protein powders are used in baked goods, snack foods, processed meats, vegetarian products, meal replacement beverages, and energy and nutrition bars. Use of whey protein powders in food systems usually combines nutrition with another functional property. Predicting nutritional quality and bioactivity of whey proteins, combined with physical properties of functionality as governed by denaturation, are increasingly important points of focus for the dairy industry as the demand for such highly specialized ingredients increases.

Whey proteins exist in their native form in the udder of the cow, with defined structure, size, charge and bound side groups. Denaturation is a major change that occurs in the structure of a protein when stress is applied to the environment of the protein. Proteins become denatured when exposed to the high heat, concentration of salts or 
organic compounds or when a change in $\mathrm{pH}$ occurs. Whey proteins begin to denature at $68^{\circ} \mathrm{C}$, below pasteurization temperatures of milk (Singh and Havea, 2003). Thus whey proteins become denatured to some degree during the pasteurization process of all milk products. The unfolding of the proteins during exposure to high heat characterizes the degree of denaturation in whey proteins, with maximum denaturation occurring at $89^{\circ} \mathrm{C}$ (Singh and Havea, 2003). Further denaturation that may occur during the recovery and processing of powdered whey proteins is not well understood. This includes denaturation as a result of liquid whey production, whey protein recovery and processing into concentrate, isolate or hydrosolate form, and during storage.

How protein structure changes that occur from native to various degrees of denaturation affect the functional and nutritional properties of whey protein is not completely understood. Current technology provides the ability to study how these functional properties are altered when whey proteins are in native or denatured forms. Determining whether and how whey protein denaturation affects functionality as an ingredient in a food system would be valuable in not only the dairy industry, but also the food industry as a whole. Manufacturing processes and storage practices for whey protein may have some effect on how whey protein interacts with other ingredients to make them better or worse for certain applications in foods (Singh and Havea, 2003; Ye, 2008).

Preliminary research, completed prior to experimentation, verified that structural differences can be quantified using several analytical methods. Furthermore, processing conditions including isolation method, heat treatment and drying method were found to promote structural differences which should be measurable by said analytical methods. 


\subsection{Literature Review}

\subsection{Whey Protein as a Food Ingredient}

\subsubsection{Commercially Available Forms of Whey Protein}

Upon concentration or isolation, water, lactose, fat and ash are removed from the total solids of liquid whey in varying amounts. This yields a wide variety of whey protein products that are used for an array of functional purposes in the food industry and is summarized in Table 2.1. Whey protein concentrates are indicated by the percent protein in numerical form following WPC (i.e. WPC80 is $80 \%$ protein), while whey protein isolate is $\geq 90 \%$ protein. While isolates are the most pure proteins, concentrates have proportionally larger amounts of lactose, fat and minerals (Fitzsimons et al., 2008).

\section{Table 2.1 Typical Composition and Applications of Whey Protein Products}

\begin{tabular}{|ccccc|}
\hline $\begin{array}{c}\text { Whey Protein Powder } \\
\text { Product }\end{array}$ & $\begin{array}{c}\text { Protein } \\
(\%)\end{array}$ & $\begin{array}{c}\text { Lactose } \\
(\%)\end{array}$ & $\begin{array}{c}\text { Fat } \\
(\%)\end{array}$ & Common Food Applications \\
\hline Whey Powder & $11-15$ & $63-75$ & $1.0-1.5$ & $\begin{array}{c}\text { Breads, bakery, snacks, dairy } \\
\text { foods }\end{array}$ \\
\hline $\begin{array}{c}\text { Whey Protein } \\
\text { Concentrate }\end{array}$ & $25-89$ & $4-52$ & $1-9$ & $\begin{array}{c}\text { High protein drinks and bar, } \\
\text { bakery, confectionary }\end{array}$ \\
\hline $\begin{array}{c}\text { Hydrolyzed Whey } \\
\text { Protein Concentrate } \\
80 \%\end{array}$ & 80 & $4-8$ & $4-8$ & Sports Nutrition \\
\hline $\begin{array}{c}\text { Whey Protein Isolate } \\
\text { Phe }\end{array}$ & $>90$ & $0.5-1.0$ & $0.5-1.0$ & $\begin{array}{c}\text { High protein beverages, bars, } \\
\text { supplements }\end{array}$ \\
\hline
\end{tabular}

Adapted from the Dairy Council of California (2004)

\subsubsection{Whey Protein Powder Manufacture}

There are two major classes of liquid whey: sweet whey and acid whey. Sweet whey is produced from production of rennet coagulated cheeses such as cheddar cheese and acid whey is produced from production of fresh cheeses such as cottage cheese 
(Mulvihill and Ennis, 2003). Sweet whey and acid whey are generally distinguished by their $\mathrm{pH}$, which are $\mathrm{pH}>6.4$ and $\mathrm{pH}$ 4.6-6.4, respectively (Fernandes de Carvalho and Maubois, 2010). The protein content of liquid whey streams is approximately $0.6 \%$ (Foegeding and Luck, 2002), and is usually concentrated or isolated prior to drying into a powder form for use as a food ingredient (Modler, 2000).

Figure 2.1 is a flow diagram for the production of whey protein powders. Starting with whey collected from cheese curd, a combination of ultrafiltration and diafiltration steps are utilized to achieve the desired concentration of protein in the liquid. Drying is the final step and typically done by spray drying.

Figure 2.1 Flow Diagram of Whey Protein Powder Manufacture

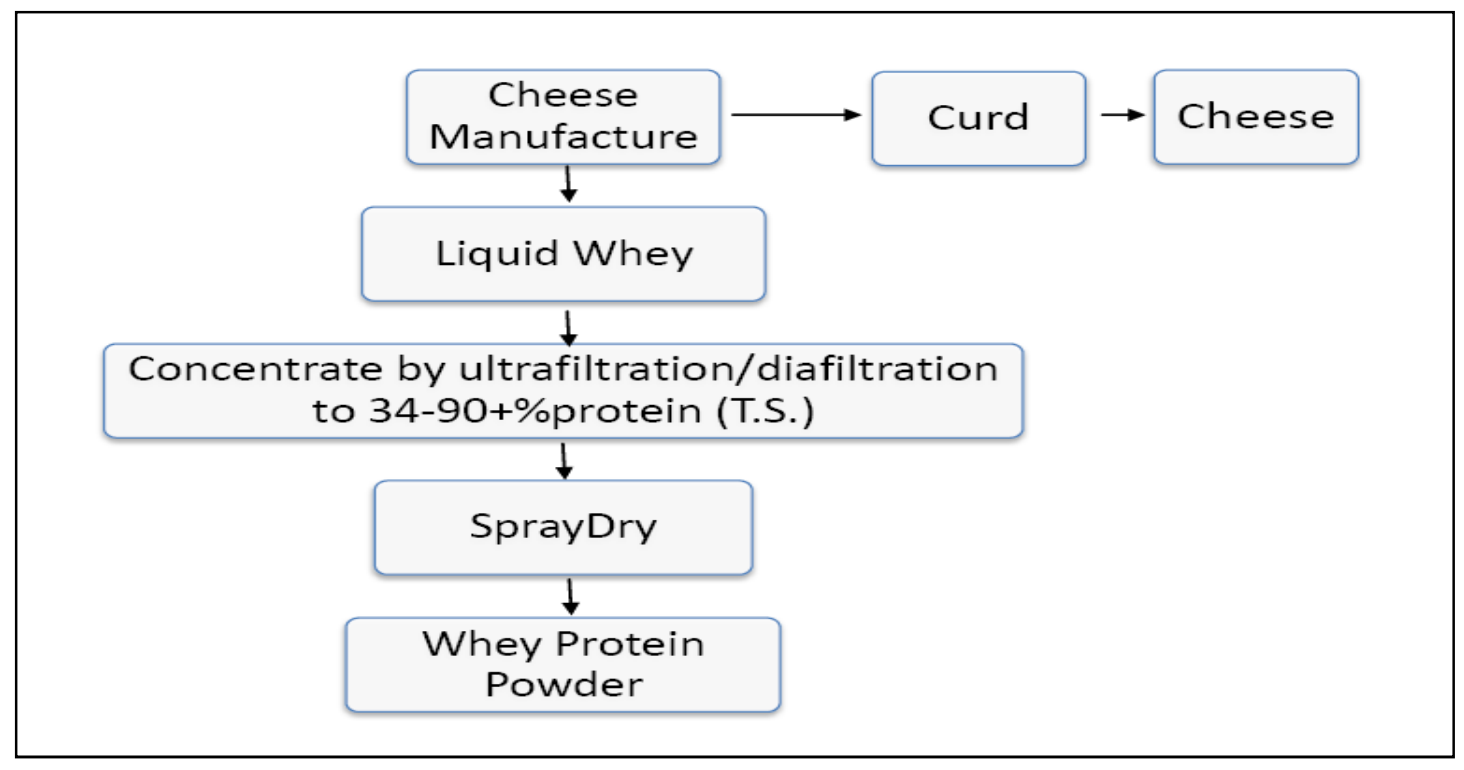

Most whey protein is obtained as a byproduct of cheese making. Recently, dairy technology to fractionate whey proteins from milk rather than cheese whey using microfiltration systems has become available (Fox, 2003). The thought is that by removing the whey fraction from milk prior to cheese production, the proteins will be less altered from their native state and will allow for better standardization of the 
processes. If whey proteins can be collected through microfiltration prior to cheese making, they would not endure the heat exposure of cheese making or come in contact with additives such as rennet, salt and coloring agents. Furthermore, removal of whey proteins increases the casein content in cheese milk, which has been shown to decrease coagulation time and increase firmness in cheese (Neocleous et al., 2002). Papadatos et al. (2003) recently evaluated the economic feasibility of microfilitration of milk prior to cheese making. In this study, they found that this method exhibited a net lower cost of cheese and whey production than conventional cheese making, due to the net increased revenue which was $\$ 1.15 / 100 \mathrm{lb}$ milk compared to the increased manufacturing cost increase of $\$ 0.135 / 100 \mathrm{lb}$. Economically, many manufacturers have not chosen to utilize this method due to lack of capacity research to support the capital investment of $\$ 300 / \mathrm{m}^{2}$ (Cheryan, 1998).

Ultrafiltration of cheese whey, the most commonly used process for isolating whey proteins in the dairy industry, utilizes a pore $\leq 0.1 \mu \mathrm{m}$ to concentrate whey proteins in liquid whey (Modler, 2000). Microfiltration is a method that is rapidly gaining use, and is another filtration method by which a small pore, often $\leq 1 \mu \mathrm{m}$, is employed to retain larger particles, such as fat and aggregated proteins, while permeating whey proteins, lactose and salts (Modler, 2000). However, when microfiltration is employed, ultrafiltration is generally required as a secondary step to microfiltration, as it involves a smaller pore sized that allows salts and lactose to permeate while and further concentrate the whey protein without fouling the membrane with larger molecular mass particles (Neville et al., 2001).

On the laboratory scale, whey proteins have often been isolated by 
ultracentrifugation as the molecular size of casein proteins causes them to sediment out of solution (Fox, 2003). However, such methods generally are reserved for small quantities, take several hours to perform and require an ultracentrifuge capable of $100,000 \mathrm{x} \mathrm{g}$ or more (Larson et al., 2006). Thus, this would not be a viable way to manufacture whey proteins, yet it is a good minimal processing method currently used in research.

A dry powdered form of the whey protein concentrates and isolate are often produced from the concentrated liquid whey in a spray drying process. Spray drying involves atomizing the liquid whey and introducing it to pre-dried, hot air, causing evaporation of water (Anandharamakrishnan et al., 2008). Alternatively, the liquid whey concentrate can be freeze-dried by a method involving a deep freeze followed by sublimation of water to powder form. However, this method is not commonly used due to the relatively high cost of the freeze drying process (Aider et al., 2007).

\subsubsection{Functional and Nutritional Properties}

\section{Uses of Whey Protein}

Protein, fat and carbohydrate are the three classes of macronutrients in food for human consumption. Sources of protein are mainly of animal origin, including meat and other animal products of dairy or poultry origin as well as legumes. Most vegetables, fruits and grains contain relatively small amounts of protein (Whitney, 2002). Derived from milk, whey protein products are generally known for being a source for protein. Whey protein powders are currently used in baked goods, snack foods, comminuted meats such as sausage, vegetarian products, meal replacement beverages, and energy and nutrition bars (Duxbury, 1993; Onwulata et al., 2001; Yetim et al., 2001).

Whey proteins are diversely used as ingredients in both dairy food systems and 
non-dairy food systems for their functional properties as displayed in Table 2.2. In dairy foods whey protein can be added to nonfat yogurt to increase physical microstructure, improving consistency (Aziznia et al., 2008). It is also used in cheese to increase yield and nutritional value or processed cheeses for the functional properties of emulsification and gelation and sensory properties (Hinrichs, 2001). Some dairy based beverages and beverage mixes often incorporate whey proteins for the purpose of viscosity and colloidal stability. Whey proteins are added to ice creams and other frozen desserts for whipping and emulsifying properties as well as bulking abilities. They are also used in reduced fat or calorie frozen dairy desserts for health purposes (Prindiville et al., 2000).

Table 2.2 Functional Uses of Whey Protein

\begin{tabular}{|c|c|c|}
\hline Functional Property & Physical Mechanism & Food Systems \\
\hline Solubility & $\begin{array}{c}\text { Solvation with molecular ions of } \\
\text { solvent }\end{array}$ & Beverages, other liquids \\
\hline Viscosity & $\begin{array}{c}\text { Thickening by entanglement } \\
\text { through covalent bonds of H-O-H } \\
\text { (H20) }\end{array}$ & Soups, gravies \\
\hline Gelation & $\begin{array}{c}\text { Protein matrix entanglement } \\
\text { resulting in setting }\end{array}$ & Meats, cheese \\
\hline Emulsification & Formation and stabilization & $\begin{array}{c}\text { Comminuted meat, soup, } \\
\text { cake }\end{array}$ \\
\hline Foaming & $\begin{array}{c}\text { Stabilization through } \\
\text { encapsulation by entrapping gas }\end{array}$ & $\begin{array}{c}\text { Whipped toppings, chiffon } \\
\text { desserts, angel cakes }\end{array}$ \\
\hline
\end{tabular}

Non-dairy based products that currently use whey protein as an ingredient are in the categories of bakery, confectionary, meat and pharmaceutical products (Mulvihill and Ennis, 2003). In bakery and baked convenience foods, whey proteins are used for their emulsifying properties. In confectionary products such as meringues and angel food cakes, whey protein is often used for its foaming properties and emulsification properties. 
In processed meat products, whey protein is used for gelation. Finally, whey proteins can be used in pharmaceuticals for microencapsulation due to the handling and dispersion properties.

Functionality of solubility, hydration capacity, viscosity, gelation, adhesion, elasticity, emulsification, foaming, are a reflection of their primary, secondary, tertiary and quaternary structures. Hence, amino acid sequence, molecular weight, charge, size and conformation all play a role in the functionality. These characteristics also determine whether a protein interacts with other proteins, fats, carbohydrates, water and other compounds to affect functionality.

In manufacturing whey protein, every aspect of the process including the type of cheese produced and the starter culture as well as the processing conditions can contribute to the functionality of the whey protein ingredient (Onwulata et al., 2004). As the protein powder industry has evolved, greater attention is being given to the quality of the powders. Whey protein powders now are produced under specified conditions to manipulate how they perform in the final application. Specifically, denaturation and aggregation can be manipulated, to some degree, to behave accordingly in cases where solubility, gelation and texturization are desired or not desired (Gaiani, 2009). This is commercially important for applications and economically important for processers to provide such specifications.

Rheological properties and/or surface reactive properties of a protein govern the functionality of whey protein ingredients. Specifically for whey protein, the functional properties of viscosity and gelation are hydrodynamic properties while solubility, water absorption, adhesion, emulsification, foaming, and flavor vehicle are all surface related 
functional properties (Pomeranz, 1985). The combination of specific functional properties characterizes the overall functionality of the protein and is dependent upon the overall environment of the protein.

\section{Solubility}

The ability of a solute to dissolve in a solvent is the functional property known as solubility (Pomeranz, 1985). Whey protein properties, including hydrophobicity and thermodynamic interactions between the protein and the solvent, as well as environmental conditions of $\mathrm{pH}$, ionic composition and interactions with other ingredients all influence solubility (Smith, 2003). Whey proteins are known for having good solubility in applications at a wide range of $\mathrm{pH}$. However, they are more soluble in high acid or high alkaline $\mathrm{pH}$ conditions due to the repulsion of molecules when shared charges are in excess resulting in high solubility (Pelegrine and Gasparetto, 2005). Alternatively, protein solubility decreases as the isoelectric point is approached. As whey proteins are soluble over a wide range of $\mathrm{pH}$, they are useful emulsifying and foaming agents especially for acidic foods like smoothies and fruit based frozen desserts.

Considering the solubility of whey protein powders, the solvent is usually water. The hydration capacity of whey protein concentrates and isolates is about one half of a gram of water per gram of protein, in comparison to soy protein which is one third of a gram of water per gram of protein (Fennema, 1996). Solubility is a crucial functional property as it is a prerequisite for several other functional properties. Viscosity, foaming, emulsification and gelation properties are all influenced by protein solubility (Onwulata et al., 2001).

When proteins undergo thermal denaturation noncovalent bonds that stabilize 
secondary and tertiary structure are broken. When the secondary and tertiary structures of a protein are unfolded, the hydrophobic $\mathrm{R}$ groups aggregate with each other and reduce water binding capacity (Pelegrine and Gasparetto, 2005). Aggregates formed by hydrophobic interactions then coagulate and precipitate out of solution, decreasing solubility when compared to native state proteins (Mine, 1995). Significant research has focused on the effects of $\mathrm{pH}$ and temperature on whey protein solubility.

\section{$\underline{\text { Viscosity }}$}

Pelegrine and Gasparetto (2005) studied the effect of temperature as a function of $\mathrm{pH}$ for whey protein solubility. Evaluating a temperature range of $40^{\circ} \mathrm{C}-60^{\circ} \mathrm{C}$ and a $\mathrm{pH}$

range of 3.5-7.8, they found that the effect of temperature on solubility is highly dependent on $\mathrm{pH}$. At $\mathrm{pH} 4.5$, close to the isoelectric points of $\alpha$-la and $\beta-\lg$, and $\mathrm{pH} 6.8$, close to neutral, the protein experienced a $22 \%$ loss of solubility when heated to $60^{\circ} \mathrm{C}$ compared to $40^{\circ} \mathrm{C}$. Alternatively, at $\mathrm{pH}$ values of $3.5,5.65$ and 7.8 , the loss of solubility over the same temperature range was negligible and sometimes solubility increased.

General food processing operations including heating, shearing, freezing and drying influence the solubility of proteins (Smith, 2003). Loss of solubility governed by an impaired rate of hydration and poor reconstitutability results in altered viscosity, gelling, foaming and emulsifying properties of reconstituted protein powders (Kher et al., 2007). Denaturation has been shown to decrease solubility, and drying processes of whey protein powders have also been known to have a negative effect on solubility (Anandharamakrishnan et al., 2008; Aziznia et al., 2008).

Viscosity is a measurement of the ability of a homogeneous, Newtonian fluid's resistance to free flow movement at a constant rate. However, most foodstuff liquids are 
non-Newtonian fluids and do not experience constant viscosity, they experience apparent viscosity that is related to shear rate (Daubert and Foegeding, 2003). Low viscosity materials flow quickly and easily and high viscosity fluids are more resistant to flow. Water adsorption and solubility of a protein influence the viscosity that the protein imparts as a functional property in a food system.

High solubility generally results in low viscosity, which is important for many food applications, especially liquid systems (Pomeranz, 1985). As whey protein is predominantly $\alpha$-la and $\beta$-lg, which are globular proteins, whey protein powders are highly soluble under native conditions. This is due to the low molecular weight and spherical, globular structures of whey proteins (Vardhanabhuti and Foegeding, 1999). Viscosity can be manipulated by protein concentration and protein denaturation in whey protein powders. For example, an increase in whey protein concentration causes intermolecular interactions of the proteins to become entangled; this leads to increased viscosity (Rattray and Jelen, 1995). Denaturation of globular whey proteins exposes R groups capable of hydrogen bonding in solution along with aggregation of unfolded proteins, resulting in higher viscosity (Schmidt et al., 1984).

Marcelo and Rizvi (2008) recently studied the apparent viscosity of liquid virgin whey protein isolate, LVWPI, which was manufactured from pasteurized, skim milk by ultrafiltration and diafiltration followed by freeze drying. They found that the apparent viscosity of LVWPI was consistently lower than commercial WPI and WPC 80, which are produced from commercial cheese whey. Furthermore, they found that protein concentration has significance in degree of viscosity, while temperature does not when evaluating the viscosity of LVWPI over a temperature range of $10^{\circ} \mathrm{C}-50^{\circ} \mathrm{C}$ at protein 
concentrations of 5-25\% by weight. This is also an important functional property for use of whey protein in beverages to incorporate a desirable mouthfeel that is achieved by low degrees of viscosity.

\section{Gelation}

Gelation is immobilization caused by network formation that suspends a dispersed phase in a continuous phase by water entrapment (Bender, 2006). Protein gelation is thought to be a result of protein unfolding (denaturation) followed by protein-protein agglomeration of the unfolded proteins, resulting in a covalently bonded network of cross linked peptides (Ju et al., 1997; Foegeding, 1992). Protein gelation is greatly influenced by the concentration of protein, the structure of protein, the surface properties of protein and physio-chemical properties of each individual protein (Marangoni et al., 2000).

Whey protein ingredients are used as a gelling ingredient for many applications. Accordingly, the gelation properties of whey proteins are commonly utilized in processed meat and cheeses and some confectionary and bakery products. The destabilizing effects of calcium or acids, heat treatments, enzymatic reactions and chemical oxidation influence the gelling capabilities of whey proteins (Onwulata et al., 2004)

Whey protein has great gelation functionality at a slightly basic $\mathrm{pH}(>8.1)$, good gelation functionality at $\mathrm{pH} 5$ and has poor gelation functionality at $\mathrm{pH} 3$ (Zayas, 1997). In order for gelation to occur, the protein must be denatured to some degree, usually by heat prior to utilization (Foegeding and Luck, 2002). This allows the native protein to unfold and re-associate via hydrogen and disulfide bonding, creating the gel matrix. The thermal processing parameters determine the gelation properties and strength.

While studying the effect of denaturation on the gelation of whey proteins, (Ju et 
al., 1997) found that gelation capabilities were a reflection of secondary and tertiary structural denaturation. It is observed that the higher percentages of the whey protein denatured prior to gelation correlated with decreased time for gelation and firming as well as increased gel strength.

\section{$\underline{\text { Emulsification }}$}

An emulsion is a mixture of two liquids that are generally immiscible. One mixture is designated the continuous phase and the other mixture assumes the dispersed phase (Pomeranz, 1985). Emulsions are not thermodynamically favorable and must be achieved through some mechanical force. Furthermore, once achieved, the emulsion is not thermodynamically stable for a significant amount of time, unless emulsifiers are utilized (Sikorski, 2001). Whey protein has the ability to stabilize such emulsions

Utilization of whey protein for emulsification is common in products such as processed meats and many dessert items. The emulsifying properties of whey protein are most affected by $\mathrm{pH}$, and tend to have poor emulsifying properties at the isoelectric point, and good emulsifying properties away from the isoelectric point (Smith and Culbertson, 2000).

\section{Foaming}

In the food industry, foam is described as a matrix where a gaseous phase is evenly dispersed throughout an aqueous phase (Bender, 2006). Like emulsions, foams require stabilizers to remain for extended time periods. Protein has the ability to stabilize

the foam. A thin film forms between the gaseous bubble and liquid phase protecting the bubbles from collapsing due to gravity, force or sheer, to stabilize the foam.

Whey protein has the ability to act as a foam stabilizer due to the surface active 
properties of $\beta$-lactoglobulin (Fennema, 1996). The $\mathrm{pH}$ and the presence of ionic compounds determine the foaming properties of whey protein. Whey protein exhibits foaming properties over a wide variety of $\mathrm{pH}$ levels, and is best at or near the isoelectric point. Salts influence protein foamability, and are removed when foaming is not desired or added when foaming is desired (Fennema, 1996). This is attributed to neutralization of charges that occurs due to the salt ions. Therefore, sodium chloride decreases foamability of whey proteins while calcium chloride and magnesium sulfate increase foamability of whey proteins. Monosaccharides and disaccharides decrease foam ability, but they increase the foam stability of whey proteins. Such is the purpose for creating the foam first then folding in sugars when processing confectionary products that rely on foaming properties for structure. It should also be noted that the stiffness of foam is directly proportional to the concentration of protein. Whey proteins have a high capacity for fat binding; however, in the presence of fat, foaming abilities decrease significantly.

Fats in whey protein powders impair the foaming ability because the surfaceactive polarity of fat interferes with protein films by situating themselves at the air/water interface (Fennema, 1996). Fat containing whey proteins thus have weak cohesive and viscoelastic bonds that are not suitable to overcome the internal pressure of air bubbles. As a result, bubbles expand and finally collapse rapidly resulting in poor foaming. However, high pressure shearing induced denaturation has been used to improve both foam overrun and stability (Dissanayake and Vasiljevic, 2009).

\subsubsection{Native Versus Cheese Whey Powders}

Heino et al. (2007) conducted a study in which they compared the functional properties of native whey and cheese whey protein powders and will be discussed in this 
section. Two native protein powders were produced from raw milk through a series of microfiltration and ultrafiltration steps followed by spray drying and freeze drying. Cheese whey from cheese manufacture was ultrafiltered, and then spray dried or freeze dried to yield two cheese whey powders. The four powders were then analyzed for the functional properties of solubility, viscosity, gelation, foaming properties, emulsifying properties and water holding capacity.

Solubility of the freeze dried and spray dried native whey protein powders had significantly higher solubility than the freeze dried and spray dried cheese whey powders, especially at $\mathrm{pH} 4$, near the isolectric point of the whey proteins. In this study, they found the drying method did not have significant effects on the solubility, but did have an effect on viscosity when comparing the two native whey protein powders. Spray dried, native whey protein concentrate had higher viscosity than the other three powders. Researchers attributed this to the fact that this powder had lower protein content, however they discussed that differences between the freeze dried and spray dried native whey protein concentrates were statistically significant which would be due to drying method.

Emulsification capacities for the four powders were similar to the results for viscosity. There were minor differences between native, freeze dried whey, spray dried and cheese whey, freeze dried and the native; spray dried powder was drastically higher. Water holding capacities were similar, with the cheese whey powder, being moderately higher than the other three powders.

The cheese whey protein concentrate powders suffered significantly lower gel strength compared to the native powders. This is likely due to the lack of casein macropeptide, a derivative of kappa casein that is found in sweet whey, in the native 
powders. Drying method did not have a notable effect on gel strength.

When evaluating the properties of foam volume, foam overrun and foam stability, the two native powders were higher than the cheese whey powders. Several factors including native structure, fat content, and the presence of other minor constituents in cheese whey are thought to explain such a difference. Spray dried powders for both native and cheese whey had better foam properties, but the effect of drying method was not as significant as the source when comparing cheese whey and native whey.

\subsubsection{Nutrition}

When defining a protein as a macronutrient, a protein is a polypeptide with more than 50 amino acids and above 6000 Daltons (Bender, 2006). This supports normal anabolic growth and maintenance of tissue, which is the primary function of protein. However, smaller peptides are thought to have other physiological impact on overall nutritional status (Hambraeus, 2003). As with fats and carbohydrates, proteins are not all nutritionally equal and have been extensively evaluated for nutritional value. Unlike fats and carbohydrates, proteins are never nutritionally viewed as anti-nutritional, rather they are categorized by nutritional superiority and inferiority. Protein quality can be described in many ways, including amino acid score, protein efficiency ratio, bioavailability, and digestibility to evaluate the nutritional quality (Sindayikengera and Shui, 2006).

Table 2.3 offers a comparison of the nutritional qualities of some common food proteins. This figure shows the nutritional superiority of whey protein compared to casein, soy, beef and wheat proteins. Egg protein is of similar nutritional quality to whey protein, however is not produced in the same magnitude as whey protein and generally relates to egg consumption as opposed to powder for application. The amino acid score 
is method which quantifies amino acids essential for human nutrition, anything over 1.00 is in excess of what is needed for human development and is therefore rounded down to 1.00 (Whey Protein Institute, 2010). Amino acid score is calculated by the following equation:

$$
A A S=\left(\frac{m g \text { amino acid in test protein }}{m g \text { amino acid in reference protein }}\right) \times 100
$$

The protein efficiency ratio (PER) is a method used to describe protein quality by calculating weight gain in relationship to protein intake when energy levels are at an adequate level (Wildman and Medeiros, 2000). This is calculated by the following equation:

$$
P E R=\left(\frac{\text { weight gain }}{\text { protein intake }}\right)
$$

The biological value of protein represents the percentage of protein that is digested and absorbed, determined by nitrogen content in food and excretions (Wildman and Medeiros, 2000). Biological value is calculated by the following equation:

$$
B V=\frac{\operatorname{dietary} N-\left(\text { urinary } N-U_{0}\right)-\left(\text { Fecal } N-U_{0}\right)}{\operatorname{dietary} N-\left(\text { Fecal } N-F_{0}\right)} \times 100
$$

Where:

N- Nitrogen

$\mathrm{U}_{0}$-Ntrogen content of urine on protein free diet

$\mathrm{F}_{0}$-Nitrogen content of feces on protein free diet

Biological value represents the amount of nitrogen retained of the absorbed protein, however does not account for the overall dietary protein retained. Digestibility is a measure taken to account for the absorption of protein overall, which is then multiplied by the biological value to express net protein utilization (NPU) (Wildman and Medeiros, 2000). Net protein utilization is calculated from the following equation: 


$$
N P U=B V \times \text { Digestibility: } \frac{\operatorname{dietary~} N-\left(\text { Fecal } N-F_{0}\right)}{\operatorname{dietary~} N} \times 100
$$

Where:

N- Nitrogen

$\mathrm{F}_{0}$-Nitrogen content of feces on protein free diet

Table 2.3 Nutritional Qualities of Common Food Proteins

\begin{tabular}{|c|c|c|c|c|}
\hline Protein Source & $\begin{array}{c}\text { Amino } \\
\text { Acid } \\
\text { Score }\end{array}$ & $\begin{array}{c}\text { Protein } \\
\text { Efficiency } \\
\text { Ratio }\end{array}$ & $\begin{array}{c}\text { Biological } \\
\text { Value }\end{array}$ & $\begin{array}{c}\text { Net Protein } \\
\text { Utilization }\end{array}$ \\
\hline Whey Protein & 1.00 & 3.2 & 100 & 92 \\
\hline Casein & 1.00 & 2.5 & 100 & 61 \\
\hline Soy Protein & $1.00^{*}$ & 2.3 & 73 & 61 \\
\hline Whole Egg & 1.00 & 3.8 & 100 & 94 \\
\hline Beef Protein & 0.69 & 2.3 & 74 & 67 \\
\hline Wheat Protein & 0.53 & 2.2 & 65 & 57 \\
\hline
\end{tabular}

Adapted from the National Research Council (1989) *Corrected for Digestibility

Whey proteins are known to be of high nutritional value for their high concentration of essential amino acids and good digestibility, resulting in high NPU (Hambraeus, 2003). All four measures of protein quality are directly or indirectly influenced by protein structure, predominantly the primary structure.

In many underdeveloped countries, lack of protein in the local diet leads to malnourishment. Whey protein is an optimal source for fortification predominantly because it is rich in several essential amino acids, including isoleucine, leucine, threonine and tryptophan, one or more of which are lacking in most grain and vegetable based proteins (Hambraeus, 2003).

Physical activity is known to exert a physical stress on muscle tissue. The supplement industry advertised that post catabolic activity, proteins should be consumed for anabolic repair of the muscles. Specific sources of protein are known to be superior 
or inferior to other proteins based on the nutritional score. Although soy protein is a cheaper protein and is often used in similar applications or in whey protein blends for bulking, there is speculation of the adverse effects that soy protein may have in men due to the high levels of estrogen (Kuzer, 2002). Furthermore, whey proteins have been highly effective in this industry because of their superior nutritional quality. Branchedchain amino acids, those with aliphatic side groups, are in relatively high proportion of whey proteins, a leading factor for why the protein scores are high (Ha, 2003). Leucine, a branched-chain amino acid found abundantly in whey, has been identified as having a large role in the translation initiation of protein tissue synthesis. Collectively, whey protein has a high protein quality score and is approximately $26 \%$ branched chain amino acids (Ha, 2001).

\subsubsection{Bioactivity of Whey Protein}

Bioactivity, also known as biological activity, is the effect that a compound has on physiological or biochemical functions, other than general nutrition, that contribute to the overall health of a person (Park, 2009). In recent years the bioactivity of food products has gained a lot of attention and several bioactive whey protein products are now available from Glanbia Nutritionals (Glanbia, 2010). Correspondingly, bioactive peptides have gained the nutritional spotlight for their many nutritional roles at the molecular level. Bioactive peptides are synthesized in the cell, which are then cleaved to impart bioactivity and are thought to have important roles in physiological functions and pathogenesis (Shi et al., 2004). In addition to promoting tissue generation which is a function of all proteins, bioactive peptides are thought to have significant physiological effects on the immune, cardiovascular, nervous and gastrointestinal systems (Madureira 
et al., 2010). Generally, functions of bioactive peptides are protective by binding to ant nutritional compounds, decreasing activity or by preventing oxidation outside the cell (Ko and Kwak, 2009).

Table 2.4 is summary of some of the bioactive functions of peptide derivatives of whey proteins. Biologically active peptides of whey proteins are naturally released by enzymatic activity during digestion as inactive precursors of whey proteins are hydrolyzed to yield bioactive peptides of 3-20 amino acids (Ko and Kwak, 2009). Controlled hydrolysis can be applied during processing either to produce bioactive peptides. This has resulted in many recent introductions bioactive peptide containing food products, including whey protein powders, to the market (Madureira et al., 2010). Starter cultures used in fermented dairy products and cheese have varying degrees of proteolytic activity. It has been observed that cultures traditionally used in dairy products have weak proteolytic activity, however current research is trending toward seeking starters with higher proteolytic capacity and how other processing conditions affect the proteolysis for to bioactive peptides (Korhonen and Pihlanto-Leppala, 2002).

It is understood that hydrolysis is necessary to produce smaller bioactive peptides from whey proteins; however there is a lack of understanding of how processing conditions affect the bioactivity of the proteins. It has been demonstrated that UHT (Ultra High Temperature) treatment, which is known to induce some degree of thermal denaturation, had a positive effect on the production of bioactive peptides through enzymatic hydrolysis (Korhonen and Pihlanto-Leppala, 2002). Bioactive peptides derived from whey proteins have been shown to be stable in vivo, yet unstable in vitro. This suggests that the delicate peptides may be susceptible to physical or gastrointestinal 
degradation (Madureira et al., 2010). The structural composition of whey proteins prior to enzyme, the digestive or fermentative hydrolysis of whey proteins is likely to have an effect on the bioactivity of the peptides in vitro. Thus, forward movement in research of bioactive peptides should be closely related to further investigation of native and denatured states of whey proteins.

Table 2.4 Highlights of Bioactivity of Whey Protein Derivatives

\begin{tabular}{|c|c|}
\hline Bioactivity & Functions \\
\hline Hypocholesterolemic & $\begin{array}{l}\text { Conversion of Angiotensin I to Angiotensin II-vasopression, control of } \\
\text { high blood pressure by dialation of blood vessels, reduce HDL } \\
\text { cholesterol, suppress cholesterol absorption, reduce total cholesterol }\end{array}$ \\
\hline $\begin{array}{l}\text { Angiotensin-Converting } \\
\text { Enzyme (ACE) }\end{array}$ & Enhance ACE activity, increase potency of other ACE activities, \\
\hline Anticarcinogenic & $\begin{array}{l}\text { Protection against colon and mammary tumors, protection against } \\
\text { oxidant induced cell death, restriction of cell division in intestinal lines, } \\
\text { treatment for restricting development and growth of tumors, reduce risk } \\
\text { of oxidation induced carcinomas, anticancer activities in organs }\end{array}$ \\
\hline Immune System & $\begin{array}{l}\text { Enhancement of immune responses, promote anti-inflammatory } \\
\text { processes, activation of monocytes-natural killer cells, enhancement of } \\
\text { mucosal immunity, reduces susceptibility to disease }\end{array}$ \\
\hline Tissue Development & $\begin{array}{l}\text { Decreases degradation of the liver, limits muscle loss during aging, } \\
\text { stimulates insulin secretion, reduces catabolism in trauma patients }\end{array}$ \\
\hline Antimicrobial & $\begin{array}{l}\text { Antimicrobial to Staphylococcus aureus, Listeria monocytogenes, } \\
\text { Salmonella sp, Escheria choli 0157:H7, antimicrobial against gram } \\
\text { positive bacteria, }\end{array}$ \\
\hline Antiviral & $\begin{array}{c}\text { Antiviral against herpes virus, bovine parainfluenza virus, hepatitis } \mathrm{C} \\
\text { virus, prevention of viral particles into the cell membrane, preventative } \\
\text { against viral caused dental carries }\end{array}$ \\
\hline Gastrointestinal & Appetite Suppressant, releases minerals \\
\hline
\end{tabular}

Adapted from Ko and Kwak (2009)

\subsection{Whey Protein Chemistry}

\subsubsection{Whey Proteins Defined}

Whey proteins are broadly categorized by those proteins remaining soluble in the liquid whey stream during cheese production. Biologically, whey proteins can also be categorized as mammary synthesized or of blood origin. $\beta-\lg$ and $\alpha$-la are both of 
mammary origin and have genetic variants with amino acid sequence variances (Creamer and MacGibbon, 1996).

Casein and whey proteins can also be qualitatively distinguished by acid precipitation. In raw milk, caseins are the group of proteins that precipitate at or below $\mathrm{pH} 4.6$ at $20^{\circ} \mathrm{C}$ and whey proteins remain soluble under these conditions (Fox, 2003). The heterogeneous group of proteins that are categorized collectively as whey proteins are comprised of approximately 50\% $\beta$-lactoglobulin $(\beta-\lg ), 18 \% \alpha$-lactalbumin $(\alpha-1 \mathrm{a})$, 5\% Bovine Serum Albumin (BSA), 10\% immunoglobulin (Ig) 17\% proteose peptones (pp), lactoferrin (lf) and miscellaneous proteins (Fox, 2003).

\subsubsection{Alpha-lactalbumin ( $\alpha$-la)}

$\alpha$-la is a globular whey protein that is produced in the mammary gland. It is well known that $\alpha$-la regulates lactose biosynthesis by forming a lactose synthase complex with $\beta-1,4$ galactosyltransferase in the bovine mammary gland (Ren and Stuart, 1993). $\alpha$ la is a small globular protein, about 14,100 Daltons that is known to have an affinity for binding calcium (Brew, 2003).

Figure 2.2 illustrates the overall structure of $\alpha$-la by crystallography (Pike et al., 1996). Representing about $18 \%$ of the whey proteins, $\alpha$-la is one of the major whey proteins and is found in milk in concentrations of $1-2 \mathrm{~g} / \mathrm{L}$ milk (Brew, 2003). This equates to roughly $18 \%$ of the whey protein and $2 \%$ of the total protein in milk (Brew, 2003). Of the three known $\alpha$-la variants A, B and C, only variant B has been identified in western cattle. The B variant of $\alpha$-la, is a globular protein with 123 residues, $3 \alpha$-helices, $2 \alpha$-helical strands and a 3-stranded anti-parallel $\beta$-sheet with a molecular weight of 14,186 Daltons (Brew, 2003). There are 8 cysteine residues in disulfide bonds and 3 
aspartic acid residues that stabilize the calcium binding loop. At $\mathrm{pH}$ lower than 4 , these bonds are broken and the calcium is lost, resulting in a partially denatured molten globular structure due to protein unfolding (Walsh and Duncan, 2000). Under favorable $\mathrm{pH}$ conditions, between $\mathrm{pH} 4.5$ and 5.5 and above $\mathrm{pH} 7.5$, mild heat induced denaturation is reversible upon cooling to $20^{\circ} \mathrm{C}$. (Walsh and Duncan, 2000).

\section{Figure 2.2 Secondary Structure of Alpha-lactalbumin}

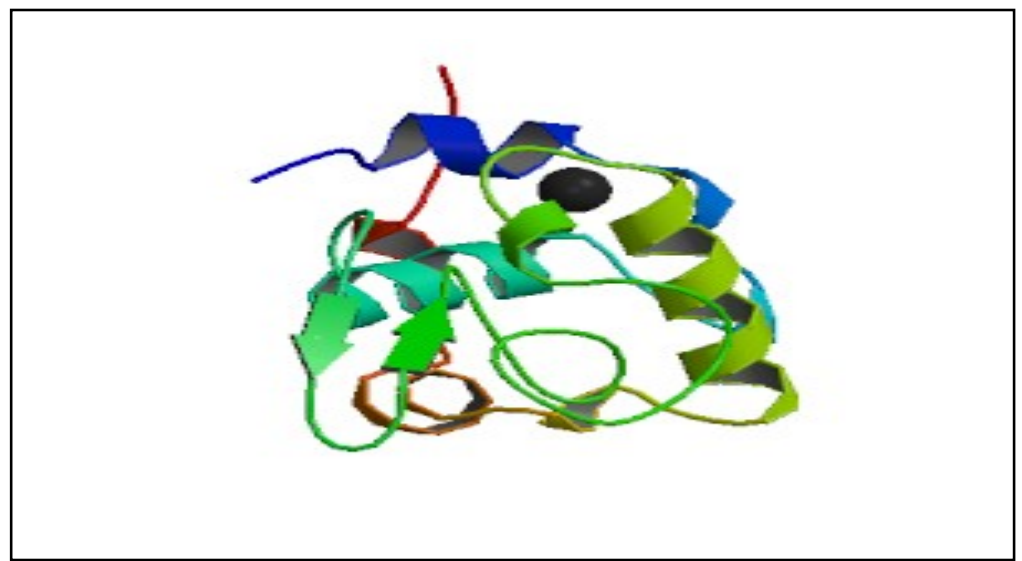

3-Dimensional globular structure determined by Pike et al. (1996)

\subsubsection{Beta-lactoglobulin $(\beta-\lg )$}

$\beta-\lg$ is another major whey protein, representing approximately $50 \%$ of the total whey protein, produced in the mammary gland and secreted in milk (Sawyer, 2003). Only ruminants and other monogastrics like cow, sheep, dog and cat secrete $\beta$-lg in their milk (Sawyer, 2003). The exact biological function of this specific whey protein is not fully understood, however there is evidence that it can bind small, hydrophobic molecules, such as retinol, alkenes and phospholipids (Perez and Calvo, 1995; Sawyer, 2003). There are 178 amino acids in the sequence for $\beta$-lactoglobulin with several genetic variants, however only variants A and B are found in western cattle. Single amino acid differences for these two variants are at residues 64 and 118 (Sawyer, 2003). 
As shown in Figure 2.3, $\beta$-lg has a crystal structure with nine strands of antiparallel $\beta$-sheet that form a calyx with a three turns of $\alpha$ helix at the C-terminal end (Walsh and Duncan, 2000). The A Variant is a polypeptide of one hundred sixty-two residues with four alpha helices and twelve beta strands and has a molecular weight of 18395.3 Daltons (Kuwata et al., 1999). The B variant is also a polypeptide of one hundred sixty-two residues, however this variant has five alpha helices and ten beta sheets and a molecular weight of 18301.3 Daltons (Qin et al., 1999). $\beta-\lg$ is has the highest molecular weight of the whey proteins.

\section{Figure 2.3 Secondary Structure of Beta-lactoglobulin}

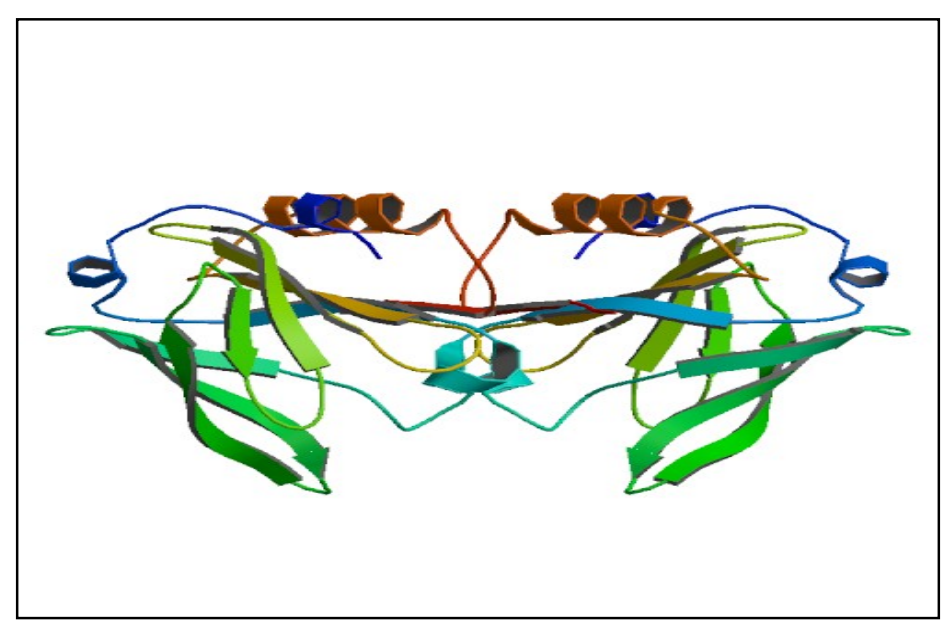

Image from: (Vijayalakshmi et al., 2010)

Amino acids 1-16 are signal peptides amino acids 17-178 make up nine strands that fold into two beta sheets (Considine et al., 2007). Each sheet has one hydrophobic side and one hydrophilic side. The two hydrophobic sides face each other creating a hydrophobic cavity. There is also a 3-turn $\alpha$-helix containing a free cysteine and 2disulfide bonds (Considine et al., 2007).

The structure of $\beta-\lg$ is $\mathrm{pH}$ dependent. Under natural $\mathrm{pH}$ conditions between 5.5 and 7.5, $\beta$-lg is usually a dimer (McKenzie and Sawyer, 1967). For $\mathrm{pH}$ less than 3, the 
protein exists as a stable monomer, from $\mathrm{pH}$ 3.7-5.2 it undergoes a reversible dimer to octamer association. While at $\mathrm{pH} 8-9.5$ it undergoes reversible dissociation. Then, at $\mathrm{pH}$ greater than 9.5 there is an irreversible denaturation (Walsh and Duncan, 2000). At temperatures up to $65^{\circ} \mathrm{C}$ under neutral $\mathrm{pH}$, changes in the tertiary structure of $\beta$-lg are reversible (Considine et al., 2007.)

In a study of heat induced denaturation of $\beta-\lg$, Sava et al. (2005) found that irreversible denaturation occurs beginning at $70-75^{\circ} \mathrm{C}$ as unfolding occurs and aggregates causing a loss of solubility at $78-82^{\circ} \mathrm{C}$. Around $80^{\circ} \mathrm{C}$, the activation of $\mathrm{SH}$ groups due to unfolding during lower heat treatment results in a decrease of protein stability affecting its solubility. Sulphydryl/disulfide interchanges reactions in an environment with a free thiol group and hydrophobic interactions cause aggregation. Heat induced denaturaton promotes this interchange reaction as free sulphydryl groups buried are exposed during unfolding and available to react.

\subsubsection{Bovine Serum Albumin (BSA)}

The biological function of BSA is protein transport for insoluble fatty acids. BSA is the only whey protein that is not synthesized in the mammary gland, it enters the milk by passive diffusion from blood streams (Walsh and Duncan, 2000). BSA accounts for approximately $5 \%$ of the protein in whey and $1 \%$ of the total protein in milk (Fox, 2003).

BSA is a polypeptide of 582 residues with a molecular weight of approximately 66,000 Daltons. BSA does not have a large effect on functional properties due to its low concentration; however it thought to have many bioactive roles (Fox, 2003). The structure consists of three domains, stabilized by a network of 17 disulfide bonds and one free thiol group (Considine et al., 2007). Secondary structure is made up of $76 \% \alpha$-helix, 
$1 \%$ turn and $22 \%$ extended chain (Carter and Ho, 1994).

At temperatures above $60^{\circ} \mathrm{C}, \alpha$-helices of BSA unfold irreversibly, and the thiol group catalyzes aggregation. Due to the high concentration of disulfide bonds in BSA, gelation occurs when heated to $70^{\circ} \mathrm{C}$ due to the intermolecular interactions. However, this is dependent upon concentration, and does not occur unless the concentration is substantially higher than naturally found in whey (Considine et al., 2007).

\subsubsection{Immunoglobulin (Ig)}

Immunoglobulins are one class of immunity compounds that transfer from the young through mammary secretions known as antibodies (Hurley, 2003). Ig account for approximately $2 \%$ of total milk protein and $10 \%$ of whey protein (Walsh and Duncan, 2000). With molecular weights ranging 20,000-70,000 Daltons, there are four classes of immunoglobulins in bovine milk, Immunoglobulin G1 (IgG1), Immunoglobulin G2 (IgG2), Immunoglobulin A (IgA) and Immunoglobulin M IgM) (Fox, 2003). IgGs are found in monomeric form in milk, while $\operatorname{Ig} \mathrm{A}$ and $\operatorname{IgM}$ are present in polymeric forms.

Due to the low concentration of Ig in whey, it is not thought to have an impact on the functional properties of the collective group of proteins. However, there is interest in the potential for passive immunity to humans, therefore structural integrity is of great interest (Hurley, 2003). Furthermore, Ig have been shown to have roles in bioactivity including, decreasing cholesterol and blood pressure, reduced susceptibility to disease and antimicrobial effects (Ko and Kwak, 2009).

\subsubsection{Other Whey Proteins}

Minor whey proteins that make up the remainder of whey protein nitrogen are lactoferrin, lactoperoxidase and proteose peptones (Fox, 2003). Lactoferrin is an iron- 
binding, transport protein that has a molecular mass of 80,000 Daltons and makes up less than $5 \%$ of whey protein (Lonnerdal, 2003). The structure of lactoferrin is two globular lobes that are attached by a long helical stretch, with iron binding sites on each lobe, however other metallic ions have been shown to be able to bind in the lobes (Lonnerdal, 2003) Lactoferrin has gained a lot of attention for the potential bioactive properties supporting the immune system (Ko and Kwak, 2009).

Lactoperoxidase is a polypeptide that makes up about $1 \%$ of whey protein that has been identified as a natural antimicrobial, especially at high concentrations, which offers a possible biological role (Pruitt, 2003). The molecular mass is of lactoperoxidase is about 78,000 Daltons and is made up of 612 amino acid residues (Pruitt, 2003).

Proteose peptones are a group of about 30 peptides that collectively represent approximately $10 \%$ of whey protein and are thought to be derivatives of casein hydrolysis and small polypeptides indigenous to milk (Fox, 2003). While the biological and physiochemical properties of the proetose peptones are poorly understood, the clearly identified PP3 has been good surface activity and is thought to play role in stabilizing foams and imulsions (Fox, 2003).

\subsection{Whey Protein Denaturation}

Native protein structure simply describes the overall structure as it is synthesized and folded. Any change in 3-dimensional confirmation, unfolding of secondary structure can be described as denaturation, any change in the structure from that of native. Generally, denatured proteins function differently than respective native proteins in terms of physicochemical activity, nutritional development and bioactivity (Rasco and Zhong, 2000). Denaturation can be induced by temperature, pressure, $\mathrm{pH}$, ionic compounds 
and/or enzymatics.

\subsubsection{Structural Changes and Relationship to Functional Properties}

The environmental conditions described above cause unfolding of the secondary tertiary and quaternary structure, allowing cross-linking of proteins to form hydrophobic, electrostatic, hydrogen bonding, and disulfide interactions. Whey protein denaturation is thought to occur in two steps. In the first step, the protein unfolds and sulphydryl interactions on the protein surface initiate covalent bonding resulting in aggregation. The second step involves further interactions resulting in aggregation (Agrawal, 2008). This results in aggregation and ultimately precipitation (Anandharamakrishnan et al., 2008).

In the past two decades here has been significant research done in effort to understand the kinetics of whey protein denaturation, yet the mechanisms of denaturation and further aggregation have yet to be fully determined. This is largely due to the effect any change in environmental conditions has in a protein system. There has been a lot of progress on characterizing the denaturation of individual whey proteins and how each is affected by temperature, $\mathrm{pH}$, shear and any combination of environmental conditions. There has also been a significant amount of research done on how environmental conditions influence whey protein powder denaturation upon use in a functional application. There is a general lack of understanding of the varying degrees of protein denaturation affects functionality for applications.

The overall chemical structure of proteins is the main factor relating to biological function. Furthermore, biopolymer protein structures are technologically important in determining their texturing, hydrating, and interfacial stabilizing functional abilities (Lefevre and Subirade, 2001). Functionality of whey protein is known to be influenced 
by the degree of denaturation, a product of processing conditions.

\section{Primary Structure}

The amino acid sequence of a protein constitutes primary structure. Covalent bonds between amino acids are associated with primary structure (Bischof and $\mathrm{He}, 2006$ ). Nutritional quality is largely determined by the amino acids in the protein, represented as an amino acid score. Designation of the linear number of the amino acid sequence always begins at the N-terminal end of the peptide. Sequences are determined by a gene specific to that protein. Hydrolysis of protein occurs during digestion in the gastrointestinal system, but can be achieved through enzymatic treatment or fermentation to yield bioactive derivatives of whey proteins (Korhonen and Pihlanto-Leppala, 2002).

Whey protein hydrolysates generally have increased solubility, decreased viscosity as well as other significant changes in foaming, gelling, and emulsifying properties compared to those of native or denatured, non-hydrolyzed proteins (Gauthier and Pouliot, 2003). Variations of functional properties of whey protein products compared to hydrosylate peptides produced by enzymatic hydrolysis are results of lower molecular weight, exposure of hydrophobic groups, and by an increased number of ionic groups (Panyam and Kilara, 1996).

Gauthier and Pouliot (2003) have studied the functional and biological properties of hydrolyzed whey protein. They reported that the functional properties exhibited by enzymatic hydrolysates are predominantly resulting from hydrolysis of $\beta$-lg peptides. Furthermore, they identified specific peptides that were involved in the stabilization of emulsions and foams. This group has also done work to explore fractionation of peptides on the basis of their charge, resulting in fractions and having improved functional 
properties. In addition to peptide fractionation, the control of peptide interactions can therefore be achieved by manipulating $\mathrm{pH}$, ionic strength, and temperature of their environment. This technology has resulted in the recent introduction of several whey protein hydrolysate products. However, the practical use of whey protein hydrolysates is inhibited by the bitter taste the process imparts. This is due to the formation of bitter peptides of low molecular weight with mainly hydrophobic amino acids (Saha and Hayashi, 2001).

\section{$\underline{\text { Secondary Structure }}$}

The 2-dimensional, conformational structure of the amino acids defines the secondary structure of the protein. Secondary structure is classified as alpha helix and beta sheet. A protein can, and most whey proteins do, have a combination of the two determined by the amino acid sequence. Generally, alpha helices are a defining characteristic of globular proteins that are compact with many folds, such as $\alpha$-la. Conversely, beta sheets are a defining characteristic of fibrous proteins that are more elongated and rigid, such as $\beta-\lg$ (Smith and Culbertson, 2000).

$\beta$-lg is a predominantly $\beta$-sheet protein consisting of a $\beta$-barrel with eight continuous ant parallel $\beta$-strands. However, upon changes in the secondary structure, the folding of bovine $\beta$-lg is accompanied by an intramolecular $\alpha-\beta$ transition. Secondary structural shifts of backbone resonances suggest that secondary structures in the native state are contains many $\alpha$-helices in the core of the $\beta$-barrel (Kuwata et al., 1999).

Disruption in the secondary structure occurs when the hydrogen bonds that stabilizes the $\alpha$-helices and $\beta$-sheets causing unfolding and random configuration of the proteins (Bischof and He, 2006). Denaturation at this level usually results in aggregation 
and precipitation.

\section{Tertiary Structure}

The overall three dimensional structure of a protein constitutes the tertiary structure. The physical relationship of the $\alpha$-helices and $\beta$-sheets of the secondary structures within the protein to one another is defined as tertiary structure. The interactions between secondary structural domains and involved in the aggregation to form the tertiary structure. This is determined by hydrogen bonding, hydrophobic and electrostatic interactions, and Van Der Waals forces and disulfide bonds (Foegeding et al., 1995). Arrangement of the tertiary structure during denatured states is thus dependent upon the assumed primary and secondary structure in the denatured state.

Whey protein denaturation involves a rearrangement of the tertiary structure so that the free thiol group from cysteine at residue 121 in $\beta-\lg$, which under native conditions is buried within the protein molecule, becomes exposed. This activated thiol group can subsequently react with disulfide bonds that are also present in $\beta$-lg or $\alpha$-la in an exchange reaction, or can react with another thiol group to form a disulfide bond (Floris et al., 2008). Such polymerization reactions allow small aggregates to form which can be used for texturization and gelation (Floris et al., 2008).

\section{Quaternary Structure}

Only oligomeric proteins, those with multiple peptide chains, exhibit quaternary structure. Quaternary structure is determined by the association of the multiple peptide chains held together by non-covalent forces. $\beta$-lg contains a free cysteine amino acid that is thought to have an important role in the denaturation of whey protein, beginning with the dissociation and association of the quaternary structure (Corredig and Dalgleish, 
1996). Denaturation of quaternary structure is highly $\mathrm{pH}$ dependent for $\beta-\lg$, as it exists as a dimer at neutral $\mathrm{pH}$ levels, a monomer at low $\mathrm{pH}$ levels and an octamer at high $\mathrm{pH}$ levels (Relkin, 1998). The form at which $\beta$-lg exists in quaternary structure plays a role in several functional properties, such as solubility, viscosity and gelation.

\subsection{Factors of Whey Protein Denaturation}

The primary, secondary, tertiary and quaternary structures of whey protein are most native in structure that is how they are naturally synthesized and assembled, in raw milk. Several factors discussed in the following sections cause denaturation of the whey proteins during processing.

\subsubsection{Temperature and $\mathrm{pH}$}

Milk borne disease causing pathogens are destroyed during pasteurization of milk. The pasteurized milk ordinance (PMO) states that every particle of milk or milk product must be held at one of the time-temperature requirements listed in table 2.5. The time temperature relationship most often used is for high temperature, short time (HTST) pasteurization is $72^{\circ} \mathrm{C}$ for 15 seconds. While pasteurization imparts the greatest heat load to whey protein during production, there are other processes that impart lower heat loads, such as cheese manufacturing, concentration and drying.

Structural changes that constitute the transition of native to denatured state of whey proteins have been extensively studied in the recent decades. For $\beta-\lg$ and $\alpha$-la, thermal transitions involving loss of globular structure and unfolding of secondary structure begin occur at $73^{\circ} \mathrm{C}$ and $66^{\circ} \mathrm{C}$, respectively (Ruegg and Moor, 1977). Thermal treatment of whey proteins results in the carboxymthlyation of cysteine in B-lg which leads to loss of B-lg cross linking (Chen et al., 2005). At these lower temperatures, 
unfolding of the proteins is generally reversible, however at more extreme temperatures, the proteins self associate or aggregate, and the denatured state becomes irreversible (Law and Leaver, 2000). Models for heat induced aggregation of $\beta$-lg has been proposed in several studies using various analytical methods to be initiated by monomers reacting with other monomers in a disulfide bonds to form aggregates (Havea et al., 2001). Under thermal treatments, denaturation has been shown to lose globular structure at $60^{\circ} \mathrm{C}$ (Ruegg and Moor, 1977). Thermodynamically, denaturation occurs when energy is transferred to a protein structure with the capability of changing the molecular confirmation. As previously discussed, this occurs in two steps: 1) activation- the kinetics of breaking an energy barrier and 2) enthalpy-the amount at which the heat is absorbed (Bischof and He, 2006).

Table 2.5 Time-Temperature Relationships for Pasteurization

\begin{tabular}{|c|c|}
\hline Temperature $\left({ }^{\circ} \mathrm{C}\right)$ & $\begin{array}{c}\text { Time } \\
(\text { Seconds })\end{array}$ \\
\hline 63 & 1800 \\
\hline 72 & 15 \\
\hline 89 & 1.0 \\
\hline 90 & 0.5 \\
\hline 94 & 0.1 \\
\hline 96 & 0.05 \\
\hline 100 & 0.01 \\
\hline
\end{tabular}

Adapted from PMO, 2007

$\beta$-lg has been extensively studied. However, the mechanics of thermal denaturation, with the exception of carboxylation, are still not understood in great detail at the structural level (Mousavi, 2008). Kinetic partitioning, a phenomenon where more than one conformation is achievable by a peptide chain, yet one conformation is more kinetically achievable than the other, is a possible explanation for the unfolding and 
subsequent aggregation well demonstrated by whey proteins (Mousavi, 2008). Thermal denaturation is likely governed by environmental conditions of the whey proteins.

Milk has a slightly acidic $\mathrm{pH}$ of approximately 6.65. The $\mathrm{pH}$ of the whey is directly related to the $\mathrm{pH}$ of the cheese curd; however the curd $\mathrm{pH}$ is usually slightly lower than the whey $\mathrm{pH}$ (Yun et al., 1995). Acid whey generally has a pH of 4.6-5.0, while sweet whey has a pH of 6.2-6.4 (Park, 2009). Liquid whey $\mathrm{pH}$ can be altered prior to further processing to promote desired functional properties. The $\mathrm{pH}$ of the final application of the whey protein ingredient has a large role in maintaining structural state and functional properties.

Tertiary and quaternary structure is altered at certain $\mathrm{pH}$ levels. When the $\mathrm{pH}$ is near $7, \beta-\lg$, which is natively a dimer dissociates into monomer, in a two step reaction beginning with unfolding followed by polymerization of the monomers through sulfhydryl oxidation and a sulfhydryldisulfide exchange reaction (Harwalkar, 1980). At $\mathrm{pH}$ levels below 3.0, $\beta-\lg$ exists in the monomeric form Conformation of protein is relatively unaffected (Mills and Creamer, 1975).

Many researchers have explored the potential $\mathrm{pH}$ effects of thermal denaturation of whey proteins (Harwalkar, 1979; Law and Leaver, 2000; Corredig and Dalgleish, 1996; Pelegrine 2005). In one study on the effect of $\mathrm{pH}$ on the thermal denaturation of whey proteins, Law and Leaver (2000) found denaturation of the four whey protein fractions, $\beta-\lg , \alpha-\operatorname{la}$, Ig, and BSA/LF, increased with heating time and varied $\mathrm{pH}$. Under the same heating and $\mathrm{pH}$ conditions, the susceptibility of the whey proteins to denaturation was in the order $\operatorname{Ig}>\mathrm{BSA} / \mathrm{LF}>\beta-\lg >\alpha$-la. For most heating conditions, the rate of denaturation of the $\mathrm{Ig}$ were highest at a $\mathrm{pH} 6.0$, decreasing to a minimum about 
$\mathrm{pH} 7.4$, increasing up to about $\mathrm{pH} 7.8$, and then decreasing slightly at $\mathrm{pH}$ 8.0. The rate of denaturation of the serum albumin/lactoferrin fraction, however, tended to be highest at low $\mathrm{pH}$, decreasing to a minimal denaturation at $\mathrm{pH} 7.4$, increasing up to about $\mathrm{pH} 7.8$, and then decreasing slightly $\mathrm{pH}$ 8.0. The rate of denaturation was at its minimum for $\beta-\lg$ near the natural $\mathrm{pH}$ of milk became. The rate of denaturation for $\beta-\lg$ increased rapidly between $\mathrm{pH} 5.2$ and 6.1, decreased to about $\mathrm{pH} 6.8$, and then increased rapidly up to $\mathrm{pH}$ 8.8. The rate of denaturation of $\alpha$-la decreased between $\mathrm{pH} 5.2$ and 6.0 , increased slightly close to $\mathrm{pH} 6.2$, and then increased fairly rapidly up to $\mathrm{pH} 8.8$.

The $\mathrm{pH}$ of heating also affects the functional properties of the whey protein. For example, that the protein which precipitated from milk heated above $\mathrm{pH} 7.5$, which is where the rate of denaturation for $\beta-\lg$ was at a minimum, had better solubility properties than that from milk heated at its natural $\mathrm{pH}$ of 6.5 , which is when the rate of denaturation of $\beta$-lg is at its highest (Grufferty and Mulvihill, 1987).

\subsection{2 $\underline{\text { Shear }}$}

Shear energy is conveyed when fluids are in motion under confined circumstances. For some processing applications, such as homogenization, shear force is intentional and yields a desired effect. However, shear stress is more often byproduct of forcing movement of a fluid through use of pumps, mixers and pipeline components (Daubert and Foegeding, 2003). Whey protein structure is affected by the shear stress applied in the force and rate used to move the liquid carriers of the proteins, namely milk, liquid cheese whey and liquid applications of whey protein ingredients. Furthermore, interest surrounds the use of high hydrostatic pressure as a possible alternative for heat treatment to destroy microorganisms in dairy products (Considine et al., 2007). 
As described by Considine et al. (2007) shear from high hydrostatic pressure induces the loss of globular structure in whey proteins. The compressibility of protein depends on the type of protein and the extent of the treatment and may affect its particle size. High pressure denaturation is induced by alteration of the equilibrium between the interactions that stabilize the folded conformation in the secondary structure of native proteins. Therefore, such the denaturation of whey proteins may have occurred due to the reduced stability of the hydrophobic core. If the globular proteins were even partially unfolded, then aggregation of molecules via disrupted hydrophobic groups would most probably result in bigger particles as shown by the change in distribution of interactions. Hydrophobic cores of whey proteins are less stable at high pressure due to loss of partial molar volume upon its local unfolding. Pressures of 100-200 MPa are sufficient to cause dissociation of quaternary structure of multi-protein complexes, however, small monomeric whey proteins are usually denatured between 400 and $800 \mathrm{MPa}$.

The application of heat and high shear has been used to achieve denaturation of whey protein ingredients when that is desired. Dissanayake and Vasiljevic (2009) demonstrated the effect of denaturation induced by high pressure processing improving foaming properties when compared to native whey protein. High-pressure shearing positively increased both foam overrun and stability in their study of functional properties of whey protein induced by high pressure shearing. The foaming properties of whey protein concentrates were significantly correlated with the amount of $\beta-\lg$, as $\beta-\lg$ is the most pressure-sensitive whey protein. Foaming properties of whey proteins are improved with high pressure as molecular flexibility and increased surface hydrophobicity are improved. This study also found that solubility increased significantly due to the 
conformational rearrangements in the quaternary and tertiary structures of whey proteins.

\subsection{Analytical Methods of Characterizing Whey Protein Denaturation}

Many basic principles of chemical analysis can be used to quantify whey protein denaturation, such as spectroscopy, chromatography, dye-binding methods, nitrogen analysis and electrophoresis (Chang, 2003). The quantification of whey protein denaturation is important for understanding behavior of functional properties and biological activity investigation (Chang, 2003). Thermograms and dichroism measure the rate at which proteins denature by heat and are commonly used. Protein solubility at $\mathrm{pH} 4.6$ is often used to quantify total and soluble proteins resulting in the expression of the percent of the total which is denatured, insoluble at $\mathrm{pH} 4.6$.

\section{High Performance Liquid Chromatography (HPLC)}

HPLC is a general term for column chromatographic methods used to separate, identify, quantify or purify compounds based on polarity, under high pressure. The separation of compounds in the sample is dependent upon the stationary and mobile phases. Partition, adsorption, ion exchange, size exclusion, affinity and chiral are the classifications of HPLC based on separation method (Skoog, et al., 2009). Reverse-Phase partition HPLC (RP-HPLC) and size exclusion HPLC (SE-HPLC) are commonly used for analysis of proteins (Rounds and Gregory, 2003).

Upon injection of a protein containing sample into the column, the sample is introduced to the mobile phased (eluent) and proceeds through the stationary phase of packed particles in the column. A detector and recording system are used to plot the concentration of compounds in the mixture as a function of time as quantifiable peaks on a chromatogram (Skoog, et al., 2009). 
Under normal phase partition HPLC, the column is full of tiny polar particles, often silica and the polar compounds in the sample will stick to the column and take longer to pass through than the nonpolar compounds in the sample, yielding a separation over time. Long chains of hydrocarbons can be attached to the column surface to make it non polar and the opposite phenomenon occurs, the nonpolar compounds will stick to the surface and the polar compounds will pass through faster. When such a column is used, the method is reverse phase HPLC (Skoog, et al., 2009).

Parris and Baginski (1991) suggested the use of RP-HPLC to determine the extent of whey protein denaturation. In this study researchers found that reversed phase-HPLC can be used to quantify undenatured whey protein which can be expressed as whey protein nitrogen, WPN, based on comparisons to highly purified standards. Specifically, the technique is used to quantify denaturation by comparing the area of the normalized peaks of a control to the peaks of a thermally denatured sample.

Researchers have found with this method it is possible to quantify the major whey proteins $\beta$-lg and $\alpha$-la using this method, however it is difficult to simultaneously quantify minor whey proteins BSA, immunoglobulin, and proteose peptone fractions (Elgar et al., 2000). However, optimizing mobile phase composition, gradient, sample size and flow rate, Elgar et al. (2000) were able to achieve simultaneous separation and quantification for whey protein isolate of $94 \%-99 \%$ of the total nitrogen, but only 81 $88 \%$ of the total nitrogen for whey protein concentrates.

Size exclusion HPLC, as the name implies, fractionates proteins on the basis of their size (Rounds and Gregory, 2003). SE-HPLC can be used to quantify denaturation based on the decrease of the peak area for each protein, reporting percent denaturation as 
a percentage of the peak area of the samples corresponding to a defined undenatured sample (Ju et al., 1997). They determined the percentage of denaturation in a control whey protein isolate, WPI solution by calculating the difference between total protein and protein content in the supernatant after performing a precipitation at $\mathrm{pH} 4.6$ using nitrogen determinations by the Kjeldahl method. WPI solutions were then subjected to a variety of heat treatments, centrifuged and analyzed for remaining protein in the supernatant. Percent denaturation was calculated by the loss of native protein compared to the control WPI protein for each of the major whey protein peaks.

HPLC is one of the most widely used analytical methods for analyzing whey proteins (Elgar et al., 2000; Ju et al., 1997; Parris et al., 1991). Versatility, short analysis time and high resolution make it one of the main techniques for analyzing protein for the dairy industry (Elgar et al., 2000). HPLC can separate compounds with molecular weights of 54 to 450,000 Daltons over a wide range of polarity, can take as little as ten minutes to run and is usually reproducible to $99 \%$ (McMaster, 2007). The power of the HPLC instrumentation lies in proper use, which is dependent upon equipment and run parameters. Varying the flow rate (pressure) and eluent material (mobile phase) the resulting efficiency of separation is affected. Elgar et al. (2000) demonstrated that these parameters can be manipulated to achieve simultaneous separation of whey proteins. RPHPLC has been shown to have good reproducibility and low variability as well (Parris and Baginski, 1991).

Cost, complexity, low sensitivity to certain compounds and difficulty of analyzing mixtures simultaneously are the major disadvantages of this HPLC (Lehr, 2009b). Initial cost of any HPLC machine is expensive; furthermore, columns and solvents are very 
expensive and have short shelf lives drastically increasing the operating costs (McMaster, 2007). The complexity of HPLC makes it difficult to optimize parameters and it can take a great amount of time to achieve desired separation. Although Elgar et al. (2000) described a method, they relied on drop lines of smaller proteins to quantify, which is not very sensitive.

\section{Fast Protein Liquid Chromatography}

Principally very similar to HPLC, Fast Protein Liquid Chromatography (FPLC) generally employs ion exchange or gel filtration chromatography methods. It is preferred to HPLC because it can handle a higher load of protein in solution (Sheehan, 1996).

Fast protein liquid chromatography is used to measure denaturation as the loss of native $\beta$-lg that occurs when it self-aggregates as a result of denaturation (Galani and Apenten, 1999). Expression of protein denatured as a loss of tertiary and quaternary structure can be reported in the same manner as HPLC, as a percentage of the total protein in a control (Manji and Kakuda, 1987). When comparing three methods used for determining thermal denaturation of whey protein, Manji and Kakuda (1987) found that the results from FPLC and Kjeldahl were not different, suggesting that FPLC appears to be comparable method to $\mathrm{KN}$ in terms of results.

\section{Bicinchoninic Acid Assay (BCA)}

The BCA Assay relies on a chemical reaction to measure protein concentration by absorbance at $562 \mathrm{~nm}$ on a spectrophotometer. This reaction is initiated by the reduction of $\mathrm{Cu}^{2+}$ to $\mathrm{Cu}^{1+}$ that occurs when whey proteins are placed in an alkaline environment. The addition of bicinochoninic acid catalyzes the colorimetric reaction detectable by 
spectrophotometery (Pierce Technology, 2010). Specifically, the amino acids cysteine, tryptophan and tyrosine are responsible for the reduction of cupric ions to cuprous ions, which react with the BCA reagent to form a purple color (Wiechelman et al., 1988). The intensity of purple is proportional to the concentration of the protein and can be compared to standards of known concentrations. An external standard curve which is then used to determine concentration of unknown samples by the signal produced by the unknown (Lehr, 2009a). BCA can be used to determine whey protein denaturation by calculating total protein and soluble protein following a pH adjustment to precipitate the denatured protein. \% Native is calculated by the following equation:

\section{$\frac{\text { Concentration in Soluble Supernatant }}{\text { Total Concentration }} \times 100$}

To my knowledge, this method has not been used as a method to quantify denaturation. However, BCA is a quick, relatively inexpensive, reproducible method. The microplate method is sensitive to $0.5-0.1 \mu \mathrm{G} / \mu \mathrm{L}$ (Chang, 2003). Some disadvantages to this method are that the color is not stable with time and requires analysis in a given window of time, reducing sugars and other peptides may interfere with the reaction (Chang, 2003).

\section{$\underline{\text { Kjeldahl }}$}

Kjeldahl nitrogen is one of the most common methods for determining protein and is the official AOAC method for dried milk (Association of Official Analytical Chemists, 1980). While there are standardized Kjeldahl procedures, several researchers have developed modified Kjeldahl methods to quantify more specifically or to decrease 
the inherent timeliness and difficulty of the known procedures (Manji and Kakuda, 1987). When using Kjeldahl nitrogen to quantify denaturation, Kjeldahl procedures must be done on a control and a treated sample, calculating \% denaturation on the basis of:

$$
\frac{\text { WPN Total }- \text { WPN Soluble }}{\text { WPN Total }} \times 100
$$

The Kejldahl Nitrogen method has been widely used for several decades and is an approved standard method, however it is also known for being time consuming and tedious (Manji and Kakuda, 1987). Kjeldahl methods are known for quantitative measurements of protein and tend to have good reproducibility and reliability.

\section{$\underline{\text { Circular Dichroism (CD) }}$}

$\mathrm{CD}$ is a spectroscopic method that measures the left and right handed polarized light that is produced by chiral molecules over a range of wavelengths. Individual whey proteins can be distinguished using this method, therefore is a common method used to study the secondary structure, $\alpha$-helix, $\beta$-sheet and $\beta$-turns, of proteins as they are affected by environmental conditions such as temperature and $\mathrm{pH}$. The response is recorded as a thermal denaturation curve that depicts the structural change compared to controls (Chen et al., 2005).

Qi et al. (1997) used FTIR, a common method which they considered reliable to study secondary structure of proteins, to evaluate the use of CD for the same application. In a study where the effect of temperature on the secondary structure of $\beta-\lg$ was measured, they found the results of the two methods had differences of $5 \%$ concluding that $\mathrm{CD}$ is satisfactory for the application. In a study to evaluate the possible use of $\beta-\lg$ as a thermal marker for whey protein denaturation, Chen et al. (2005) found that $\beta-\lg$ has severe loss of native structure when treated at $80^{\circ} \mathrm{C}$ for 15 seconds using CD. 
Both Chen et al. (2005) and Hong and Creamer (2002) have used CD to study the rate of denaturation, characterized by loss of native structure, and validated with electrophoretic techniques.

$\mathrm{CD}$ is a sufficient method for predicting secondary structure, especially $\alpha$-helices and $\beta$-sheet, making it a good method for analyzing globular whey proteins. Standard reference spectra are available for whey proteins to assist in interpretation, which can be very tricky (Tremblay et al., 2003). Furthermore, denaturation is not easily detectable by CD.

\section{Polyacrylamide Gel Electrophoresis (PAGE)}

Electrophoresis is an analytical method in which charged molecules are measured by their migration through a charged field based on net charge and applied voltage (Smith, 2003). PAGE is a common electrophoretic method used for proteins that can be manipulated in many ways to separate proteins. Under native conditions, proteins separate based on size, charge and shape of molecule. Sodium Dodecyl Sulfate (SDS) is a dissociating agent used to denature all proteins into individual polypeptides. $\beta$ mercaptan is often used as a reducing agent to disrupt all disulfide bonds to analyze proteins based on molecular weight and size uniformly. SDS-PAGE is a very widely used technique due to its ability to analyze a wide range of molecular weights, from 5150kDa (Considine et al., 2007).

As SDS denatures all proteins, it is not possible to characterize the structure of the proteins. For structural analysis using PAGE, native conditions are utilized. Omission of SDS and reducing agents allows the proteins to run based on their mass charge and molecular weight as proteins. However, with native PAGE, aggregate of denatured whey 
proteins can be too large to enter the gel and remain in the sample well (Anand et al., 1998). Protein aggregation, indicative of denaturation, can be studied using twodimensional (2-D) PAGE. This can be an alternative method to measuring degrees of denaturation specifically of one dimensional (1-D) PAGE. 2-D PAGE separates initial mixtures (aggregates) of proteins while leaving disulfide bonds intact. In the first dimension, the proteins and aggregates are separated into bands, then a reducing agent is applied and the second dimension separates polypeptides allowing detection of disulfide aggregates (Considine et al., 2007). Havea et al. (2001) used this method analyzed the aggregation of whey proteins in untreated, heat treated and pressure treated $\beta-\lg$. They were able to identify bands attributed to dimer and trimer aggregates of $\beta$-lg in the heat and pressure treated samples. It was also noted, however that such denaturation resulting in dimerization may have been induced through oxidation of thiol groups during sample preparation or electrophoresis.

SDS-PAGE has also been employed to detect the loss of native whey proteins using a laser densitometer and simply attributing the loss of total protein to aggregation by Galani and Apenten (1999). They suggest that mildly denatured proteins, noncovalently linked aggregates, are dissociated into monomers, while aggregates linked by disulfide bonds will not dissociate without a reducing agent. Thus it is possible to quantify denaturation by loss of native proteins using densitometry. While there is merit to this statement, it does not account for the thermal denaturation or other possible reactions that occur when using the SDS method.

PAGE is a widely accepted method due to its reliability. Compared to many other analytical methods, PAGE is relatively easy to run. Using this approach, however, does 
not account for the proteins that have a lower degree of denaturation and have not aggregated. It is difficult to compare density of bands from one gel to another due to inherent differences in the gel's initial composition and protein bands determined by factors of loading volume, run time, stain strength and time.

\section{Capillary Electrophoresis (CE)}

Another electorphoretic method, $\mathrm{CE}$ is the first that does not require a flat stabilized, solid or semisolid medium (Skoog, et al., 2009). Rather, a silica fused capillary tube is the medium for mobility between two reservoirs of buffer. Quantitative analysis for whey protein denaturation results can be attained using CE by conducting a reference curve for each protein to compile a standard curve. This can be very time consuming as it involves all components of each protein and must include genetic variants of each protein in native and denatured states.

Ardö et al. (1999) described the use of CE for quantitative analysis for whey protein denaturation to monitor heat load of milk. They found that significant loss of the native structure in whey proteins, specifically of $\beta-\lg$, can be used to quantify denaturation. Quantitative results can be attained using CE in this method by conducting a reference curve for each protein to compile a standard curve. This can be very time consuming as it involves creating internal standards for each protein with purified proteins and must include genetic variants of each protein in native and denatured states. They concluded that while this is an effective technique, the complexity and analytical equipment currently required make it impractical for the dairy industry.

However, CE is advantageous over other methods of electrophoresis due to online detection coupled with detectors which enhance sensitivity and resolution, which are 
common for chromatography methods (Tremblay et al., 2003).

\section{Fourier Transform Infrared Spectroscopy (FTIR)}

The structural characteristics of food proteins have been studied by Fourier transform infrared (FTIR) spectroscopy to determine their protein structures. Valuable information at the molecular level is gained by analyzing the amide regions of infrared spectra where vibrations originate from the amide vibrations of the peptide bonds in the secondary structure. As proteins denature, they adopt secondary structures which differ in the geometry and hydrogen bond strength when compared to the native conditions. Consequently the secondary structures of a protein give rise to vibrations located at specific wavenumbers in the infra-red region of spectroscopy (Lefevre and Subirade, 1999). Due to the close proximity of the vibrations, a beam splitter is used to divide radiation directed at moving and stable mirrors and then recombine at which point the intensity by which the interference creates is detected creating an interferorgram (Tremblay et al., 2003). A mathematical treatment known as Fourier Transform Deconvolution is then applied to the interferogram to convert it into IR spectra.

FTIR is a common method for determining the amide I and amide II regions of secondary structure, specifically the polypeptide backbones of proteins while in solution (Qi et al., 1997; Bischof and He, 2006). Parris et al. (1991) used FTIR to quantify thermal denaturation of whey proteins in skim milk at a more detailed level compared to HPLC and PAGE. They described a method for interpreting the spectra by monitoring the amide I region for conformational changes due to the high number of peptide bonds in the backbone of this region. In their study of thermal denaturation of whey proteins, researchers found that all five major bands in the amide I region when heated to $85^{\circ} \mathrm{C}$ for 
30 minutes, and two new bands appeared when compared with known standards. They conclude that this is indicative of aggregation in the two stage denaturation process.

Most FTIR instrumentation now come with self deconvolution software built in, making easier than historically when researchers had to physically apply the fourier transform deconvolution. However, the complexity and cost of the equipment still make the FTIR a daunting method for quantification of protein denaturation. Overall loss of native structure can be determined using FTIR, however deconvolution of the spectra is necessary to gain insight into the structural changes in each of the amide regions that are affected by denaturation.

\section{Fluorescence Spectroscopy}

Fluorescence spectroscopy, or spectrofluorimetry, is an analytical method in which the photoluminescence of an analyte produces quantifiable fluorescence during the spectroscopic process of radiation of matter as a function of wavelength. Molecules with a high degree of rigidity in their conformation are capable of producing such fluorescence. As a two-photon process, there is an excitation wavelength and an emission wavelength. This differs from other spectrophotometry methods because a beam of wavelength in one direction excites the sample which and a beam of a higher wavelength at a ninety degree angle from the excitation wavelength emits a fluorescent spectrum (Skoog, et al., 2009). The values are expressed as relative fluorescent power, $F$.

Tryptophan is a well known luminescent amino acid that has been used extensively in fluorescence spectroscopy. $\beta$-lg contains tryptophan at residues 19 and 61 of the amino acid sequence, which under native conditions are buried in the globular structure of the protein. Whey protein denaturation can be monitored using fluorescence 
spectroscopy by monitoring changes in fluorescent intensity and emission wavelength (Strasburg and Ludescher, 1995).

Anand et al. (1998) used fluorescence spectroscopy to study thermal denaturation of whey protein and were able to successfully characterize a two step denaturation process using the method. In this study, they found that tryptophan fluorescence increases linearly with an increase of heat treatment from $71.1^{\circ} \mathrm{C}$ to $79.4^{\circ} \mathrm{C}$, and reaches a ceiling at $79.4^{\circ} \mathrm{C}$, observing no difference at $82.2^{\circ} \mathrm{C}$ all having hold times of three minutes. Conversely, Marangoni et al. (2000) found a fourfold decrease in fluorescent intensity from native to completely thermally denatured whey protein treated for thirty minutes at $80^{\circ} \mathrm{C}$. These discrepancies suggest that the much postulated two phase denaturation may be demonstrated by these two research groups. It is possible that both data are correct in claiming that denaturation is observed, while an increase may represent the first phase of denaturation, unfolding of the proteins and exposing fluorescent tryptophan residues. Subsequent decrease in fluorescence intensity is evident of aggregation, where the tryptophan residues are no longer exposed.

Fluorescence spectroscopy is advantageous due to its high sensitivity and non invasive technique with minimal preparation make fluorescence spectroscopy a highly favorable method for determining protein characteristics (Diez et al., 2008).

\subsection{Justification of Research}

The majority of the studies on heat induced whey protein denaturation have been carried out on whey proteins using WPI (whey protein isolate) or WPC (whey protein concentrate) which have higher protein concentrations than bovine whey/milk or in reconstituted milk or whey. Liang et al. (2006) noted that research on whey isolated from 
fresh raw milk was lacking and did a study to develop a method to isolate whey proteins from fresh raw milk. In addition, other studies have focused on individual whey proteins rather than the collective group of whey proteins. (Agrawal et al., 2008).

There lacks a standard analytical method to quantify denaturation of whey protein. Furthermore, how the many methods currently being used to characterize and quantify whey protein denaturation relate to one another unclear. Native PAGE offers a true separation to quantify the components of whey proteins. Fluorescence spectroscopy offers insight to the denaturation of a proteins secondary structure, which is greatly influenced by irreversible denaturation. BCA assay is a method used to quantify complete denaturation from aggregation and precipitation of whey proteins. These three methods were selected for their differences in measuring protein denaturation at various structural levels and their applicability to industry as they are relatively low in cost, easy to run and have short analysis times.

Furthermore, it is not completely understood whether any of the methods currently employed correlate to functional properties of whey proteins. As solubility is known to be highly impacted by whey protein denaturation and has influence on many other functional properties, this functional property was selected to compare to results of predicted denaturation by analytical methods.

Table 2.6 summarizes the pros and cons of methods commonly used to quantify whey protein denaturation. 
Table 2.6 Common Methods for Measuring Whey Protein Denaturation

\begin{tabular}{|c|c|c|}
\hline Method & Pros & Cons \\
\hline $\begin{array}{l}\text { High Pressure Liquid } \\
\text { Chromatography (HPLC) }\end{array}$ & $\begin{array}{l}\text { Versatility of measuring } 54 \text { to } \\
450,000 \text { Dalton proteins, short } \\
\text { time analysis, high resolution, } \\
\text { good reproducibility }\end{array}$ & $\begin{array}{l}\text { Cost, complexity, not } \\
\text { ideal for protein mixtures }\end{array}$ \\
\hline $\begin{array}{c}\text { Fast Protein Liquid } \\
\text { Chromatography (FPLC) }\end{array}$ & $\begin{array}{l}\text { Versatility, short time analysis, } \\
\text { high resolution (but lower than } \\
\text { HPLC), good reproducibility, } \\
\text { specific of proteins }\end{array}$ & Cost, complexity \\
\hline $\begin{array}{l}\text { Bicinochoninic Acid Assay } \\
\text { (BCA) }\end{array}$ & $\begin{array}{l}\text { Relatively low cost, good } \\
\text { sensitivity, reproducibility }\end{array}$ & $\begin{array}{l}\text { Unstable over long } \\
\text { periods of time, } \\
\text { interference of some } \\
\text { compounds, sample } \\
\text { preparation }\end{array}$ \\
\hline Kjeldahl Nitrogen $(\mathrm{KN})$ & $\begin{array}{l}\text { Approved method (AOAC), } \\
\text { good reproducibility }\end{array}$ & Time consuming, tedious \\
\hline Circular Dichroism (CD) & $\begin{array}{l}\text { Good at predicting secondary } \\
\text { structure, standard reference } \\
\text { data available for whey proteins }\end{array}$ & $\begin{array}{l}\text { Only accounts for } \\
\text { changes in secondary } \\
\text { structure, difficulty in } \\
\text { interpreting results }\end{array}$ \\
\hline $\begin{array}{l}\text { Native-Polyacrylamide Gel } \\
\text { Electrophoresis (PAGE) }\end{array}$ & $\begin{array}{c}\text { High reproducibility, } \\
\text { simultaneous evaluation of all } \\
\text { whey proteins, relatively } \\
\text { inexpensive }\end{array}$ & $\begin{array}{l}\text { Can be difficult to } \\
\text { quantify, variability from } \\
\text { gel to gel, denaturation } \\
\text { measured in terms of } \\
\text { apparent aggregation }\end{array}$ \\
\hline Capillary Electrophoresis (CE) & $\begin{array}{l}\text { Good reproducibility, high } \\
\text { resolution }\end{array}$ & $\begin{array}{l}\text { Difficult to avoid some } \\
\text { adsorption to the polar } \\
\text { phase }\end{array}$ \\
\hline $\begin{array}{l}\text { Fourier-Transform Infrared } \\
\text { Spectroscopy (FTIR) }\end{array}$ & $\begin{array}{l}\text { Short analysis time, high } \\
\text { resolution, high sensitivity }\end{array}$ & $\begin{array}{l}\text { Cost, Complexity, } \\
\text { Difficult to interpret } \\
\text { results }\end{array}$ \\
\hline Fluorescence Spectroscopy & $\begin{array}{l}\text { Good Reproducibility, high } \\
\text { sensitivity, short analysis time }\end{array}$ & $\begin{array}{l}\text { Values are absolute, } \\
\text { mostly influenced by } \beta-1 \mathrm{~g}\end{array}$ \\
\hline
\end{tabular}

\subsubsection{Significance of Research to Dairy Industry}

Very little is understood about how protein structure changes that occur from native to various degrees of denaturation affect the functional properties of whey proteins. Current technology provides the ability to study how these functional properties are altered when whey proteins are in native or denatured forms. Determining whether 
and how whey protein denaturation affects functionality as an ingredient in a food system would be valuable not only the dairy industry, but also the food industry as a whole.

Although the scope of this research focuses on the quantification of protein denaturation and the relationship of denaturation to solubility, this research on structural analysis is important to the future research of bioactivity of whey proteins. Specifically, how protein denaturation affects bioactive functions of whey proteins including gastrointestinal function, immunological development and function and microbial activity (Park, 2009).

\subsubsection{Research Hypotheses and Objectives}

Hypotheses:

1. Whey protein obtained through non-invasive processing procedures will have the most native structure.

2. Various analytical methods that determine denaturation based on primary, secondary, tertiary or overall structure vary in measured response.

3. Measurements of denaturation are related to functional properties of whey protein.

Objectives of research:

1. Characterize "Native" whey proteins.

2. Evaluate how different analytical methods respond to varying degrees of protein denaturation.

3. Determine if there is a correlation between denaturation as quantified by analytical and physical solubility.

Please note that this body of research was segmented into two experimental 
designs, each of which encompassed several individual experiments. For the purpose of simplification, all experiments included in the first experimental design will be referred to collectively as "Experiment 1" and all experiments included in the second experimental design will be referred to collectively as "Experiment 2" for the remainder of this paper. 


\subsection{Materials and Methods}

\subsection{Experiment 1}

Experimental series 1was a split plot experimental design with isolation and heat treatment being the two variable factors and a response variable of denaturation measured by native PAGE, BCA and Fluorescence Spectroscopy.

Table 3.1 and figure 3.1 offer a tabular and diagramed outline of this experiment. This is brief outline; the experimental methods are described in detail in the proceeding sections. Milk was obtained during the 3:00pm milking of the herd by locating the cows and collecting approximately one gallon of milk from each into ten gallon milk can. Milk was then transferred to the Dairy Product Technology Center (DPTC) and refrigerated. The pooled milk was then split into three plots for whey protein isolation, one plot received membrane filtration, another centrifugal force and the third enzyme coagulation. Liquid whey from each of the isolation plots was then pooled and split into three plots for heat treatment, no heat, mild heat and high heat. All samples were then refrigerated for four hours to equilibrate in temperature. Each of the nine treatments was then analyzed using PAGE, BCA and Fluorescence Spectroscopy for quantification of native structure. All analysis was performed in duplicate. Statistical analysis was performed on the data using SAS statistical software

\section{Table 3.1 Statistical Design of Experiment 1}

\begin{tabular}{|c|c|c|}
\hline Factor & Treatment & Response \\
\hline \multirow{3}{*}{ Isolation Method } & Membrane Filtration & \multirow{6}{*}{$\begin{array}{l}\text { Denaturation Measured by: } \\
\text { Native Polyacrylamide Gel } \\
\text { Electrophoresis (PAGE), } \\
\text { Fluorescence Spectroscopy } \\
\text { and Bicinchoninic Acid Assay } \\
\text { (BCA) }\end{array}$} \\
\hline & Enzyme Coagulation & \\
\hline & Centrifugal & \\
\hline \multirow{3}{*}{ Heat Treatment } & No Heat & \\
\hline & Mild Heat & \\
\hline & High Heat & \\
\hline
\end{tabular}




\section{Figure 3.1 Design of Experiment 1}

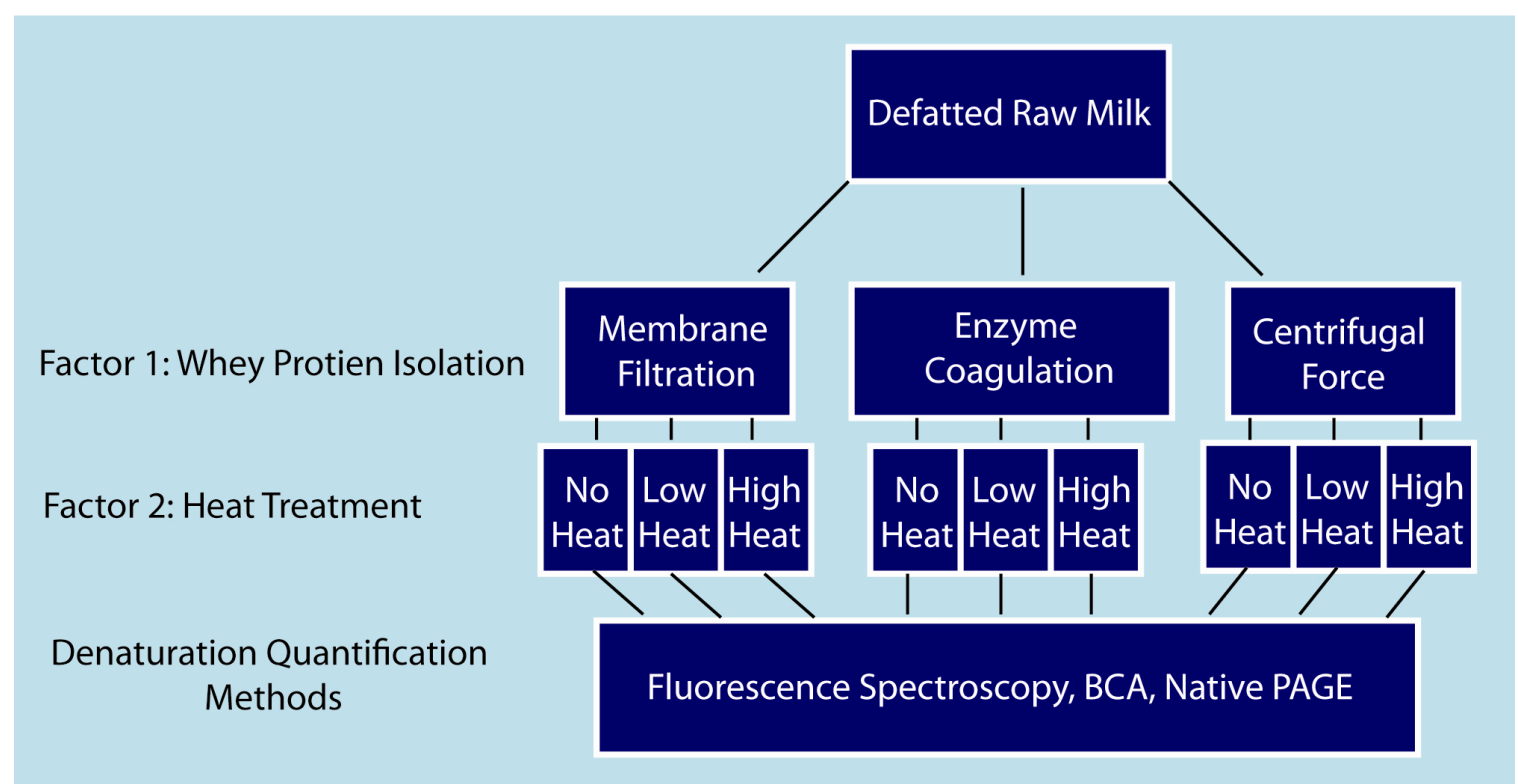

Key: Bicinchoninic Acid Assay of pH 4.6 Soluble Protein, PAGE- Polyacrylamide Gel Electrophoresis

\subsubsection{Skim, Raw Milk}

Four Holstein cows from the Cal Poly Dairy were selected for first lactation, and mid lactation, and mastitis free by the Cal Poly Dairy herdsman. The same cows were used for all replications. Selected cows were located during the afternoon milking session and approximately one gallon was collected from each cow into the same ten gallon milk can before redirecting the milk to the bulk tank. Combined, the four gallons of raw milk were then transferred to the DPTC walk in refrigerator at $50^{\circ} \mathrm{C}$ using a push cart. Milk was immediately batch skimmed in 5 batches. To skim, raw milk was ultracentrifuged in an L7-35 ultracentrifuge (Beckman Coulter, Brea, CA) at $4000 \mathrm{x}$ g for 25 minutes at $4{ }^{\circ} \mathrm{C}$ in $250 \mathrm{~mL}$ aliquots using ultracentrifuge tubes (Beckman Coulter). A metal spatula was used to remove the cream layer from each centrifuge tube. Skim milk was then pooled by recombining in a 5 gallon plastic container and divided into three 2 gallon plastic containers and held at $50^{\circ} \mathrm{C}$ for immediate liquid whey isolation. 


\subsubsection{Enzyme Isolation}

An Isotemp 210 waterbath (Fisher Scientific, Pittsburgh, PA) was set to $35^{\circ} \mathrm{C}$ and two $150 \mathrm{~mL}$ aliquots of skim, raw milk were brought up to $35^{\circ} \mathrm{C}$ in the water bath. When temperature was reached, $1 \mathrm{ml}$ of CHY-MAX enzyme coagulant (Chr-Hansen, Milwaukee, WI) was added and the liquid was stirred using a transfer pipette. All temperatures were monitored using a Traceable digital thermometer (Fisher Scientific). After enzyme coagulant was added, coagulation set for thirty minutes to simulate cheese coagulation. A metal spatula was used to disrupt and stir the coagulant and whey. Six 50mL Falcon centrifuge tubes (Becton Dickenson Labware, Franklin Lakes, NJ) were filled with the mixture and centrifuged in a 5810R bench top centrifuge (Eppendorf , New York, NY) at $1000 \mathrm{x} g$ for thirty minutes at $4{ }^{\circ} \mathrm{C}$. Liquid whey was gently poured off of the coagulant into a $250 \mathrm{~mL}$ glass jar and refrigerated at $3^{\circ} \mathrm{C}$ for four hours prior to heat treatment.

\subsubsection{Membrane Filtration}

A membrane filtration system was set up in the DPTC pilot plant specifically for this experiment. Membralox 1T1-70 Stainless steel housing (Pall Corporation, Port Washington, NY) containing a 100nm zirconium oxide mono channel element membrane (GEA Filtration, Hudson, WI) was attached to a ten gallon hopper through a Tri Clover pump and recirculation plastic tubing on the other side using o-rings and clover clamps.

Approximately two gallons of the skim milk allotted for this treatment were poured into the hopper. The pump was turned on and ran at 100 PSI until $400 \mathrm{~mL}$ of liquid whey permeate had been collected into a graduated cylinder by attaching plastic tubing to the permeating port of the membrane housing. Figure 3.2 is a schematic of how 
the column was set up. Whey was collected at a rate of $25 \mathrm{~mL} / \mathrm{minute}$. Liquid whey was refrigerated at $3^{\circ} \mathrm{C}$ for four hours prior to heat treatment.

Figure 3.2 Membrane Filtration Schematic

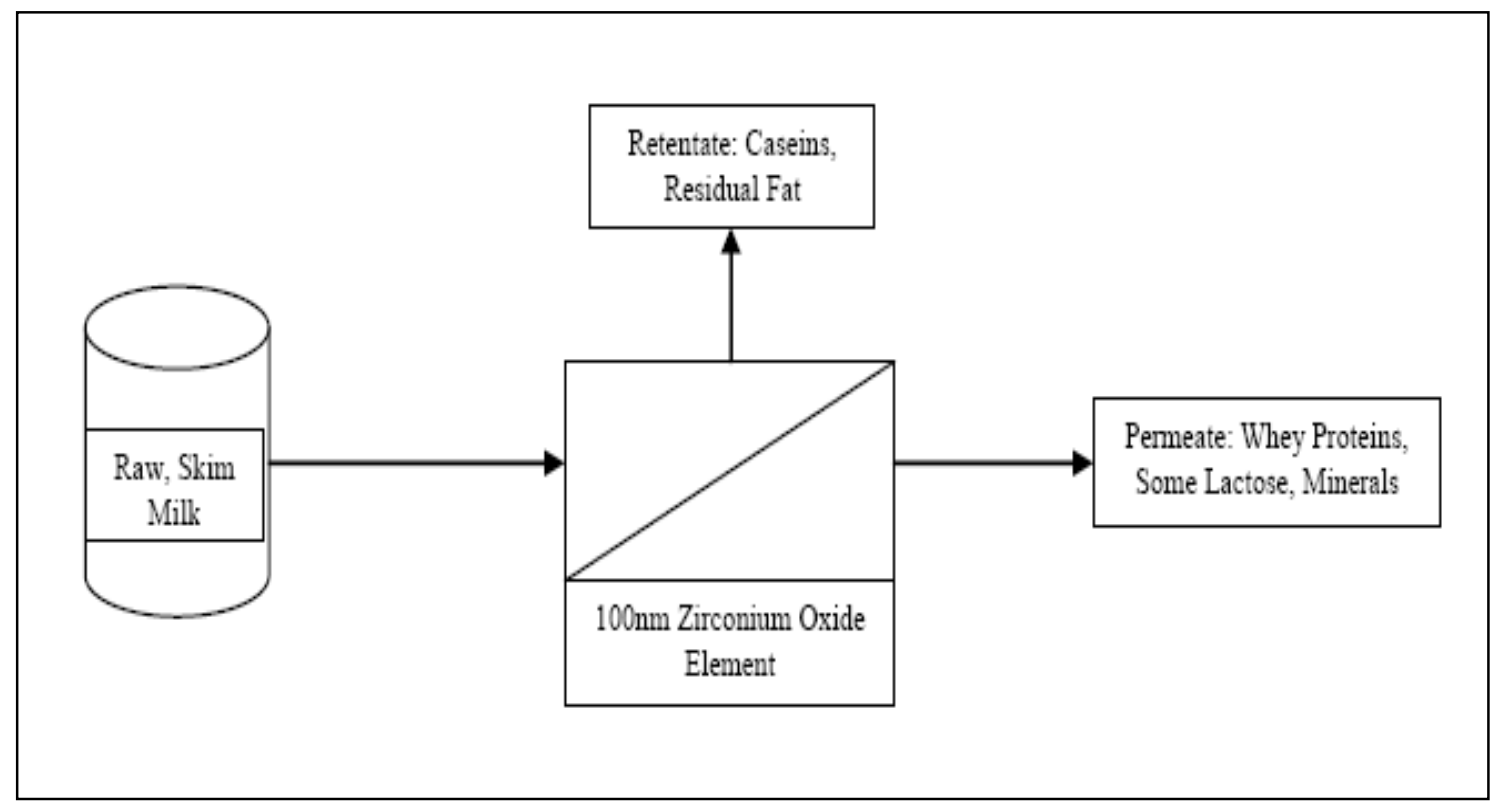

\subsubsection{Centrifugal Isolation}

Eight polycarbonate ultracentrifuge tubes (Beckman Coulter, Brea, CA) were filled with $40 \mathrm{~mL}$ of skim milk and weighed so all tubes were within a 0.5 gram range for balance in the centrifuge. Tubes were then ultracentrifuged (Beckman Coulter) for 3 hours at $62,000 \mathrm{x}$ g at $4{ }^{\circ} \mathrm{C}$. Liquid whey was gently poured off of the concentrated casein pellet into a glass jar then refrigerated at $3^{\circ} \mathrm{C}$ for four hours prior to heat treatment heat treatment.

\subsubsection{Heat Treatment}

An Isotemp 210 water bath (Fisher Scientific, Pittsburgh, PA) was set to $76^{\circ} \mathrm{C}$ for the mild heat treatment and to $85^{\circ} \mathrm{C}$ for the high heat treatment. Four $25 \mathrm{~mL}$ glass culture tubes (Pyrex \#9820, Union City, CA) were filled with each of the three liquid whey 
samples and 2 of each were placed in a test tube rack in the $76^{\circ} \mathrm{C}$ water bath. Using a digital Traceable thermometer (Fisher Scientific), the samples were brought up to $76^{\circ} \mathrm{C}$ and held for 15 seconds. Samples were then transferred to $50 \mathrm{~mL}$ centrifuge tubes (Fisher Scientific) for storage and refrigerated at $38^{\circ} \mathrm{C}$ for four hours. The remaining two tubes of each liquid whey were placed in the $85^{\circ} \mathrm{C}$ water bath, using the same digital thermometer were brought up to $85^{\circ} \mathrm{C}$ and held for 3 minutes. Again, samples were transferred to $50 \mathrm{~mL}$ centrifuge tubes for storage and refrigerated at $38^{\circ} \mathrm{C}$ for four hours.

\subsubsection{Native PAGE}

$1 \mathrm{~mL}$ aliquots of liquid whey samples from each of the nine treatment combinations were diluted with deionized water to bring the protein concentration to $5.4 \mu \mathrm{g} / \mu \mathrm{L}$. Native sample buffer, prepared by omitting SDS from Laemmli sample buffer (BIO-RAD, Hercules, CA) according to the label, was added in a 1:1 ratio with an aliquot of each treatment sample in $1.5 \mathrm{~mL}$ centrifuge tubes and mixed on a Vortex Genie 2 (Scientific Industries, Bohemia, NY) for ten seconds.

Precast $12 \%$ Tris-HCL polyacrylamide gels (BIO-RAD) were assembled in a single row AnyGel stand (BIO-RAD) and loaded with 10uL of each sample. The Criterion Cell buffer tank (BIO-RAD) was filled with a $10 \%$ tris-glycine tank buffer solution (BIO-RAD) and run at 100 volts on a PowerPac 300 electrophoresis power supply unit (BIO-RAD) until bands reached the bottom of the gel. This took approximately 2 hours. After disconnecting the buffer tank from the power supply unit, the gels were taken out of the stand and pried open using a metal spatula. The spatula was then used to carefully remove the gels from the plates and gels were placed in tupperware containers containing new Coomassie blue stain (BIO-RAD), designated for 
native PAGE. They were then placed on an InnOVA 2000 platform shaker (New Brunswick Scientific, Edison, NJ) at 55RPM for 24 hours. Stain was carefully poured off the gel and replaced with a destain solution prepared with $40 \%$ methanol, $10 \%$ acetic acid, 50\% DI water, then returned to the shaker for another 24 hours, replacing destain solution after 8 hours and after 16 hours, disposing in the appropriate waste containers.

The gels were analyzed by band imaging and densitometry using a Universal Hood II (BIO-RAD) and Quantity One software (BIO-RAD). Trans white was the selected scanner on the software and hood. DI water was used to lightly cover the tray to prevent the gel from sticking, making sure there were no air bubbles under the gel. The density of the bands corresponding to $\alpha$-la and $\beta$-lg were determined by first detecting gel background and framing each lane in the band analysis tabular section of the program. Still in band analysis, bands densities were calculated by detecting bands. The sum of the bands corresponding $\alpha$-la, $\beta$-lg and BSA was reported as the total density. Assuming a linear relationship of total protein and native protein, the density was highest for samples containing the most native structure and lowest for samples containing the most denatured structure.

\subsubsection{Fluorescence Spectroscopy}

An FP-6500 Spectrofluormeter (Jasco, Easton, MD) located in the Cal Poly chemistry department, was used for this experiment. A $10 \mathrm{~mm}$ quartz cuvette with four optical sides (Fisher Scientific, Pittsburgh, PA) was used for all fluorescence measurements. The instrument is connected to a Dell computer with the respective software for the instrument, spectra manager (Jasco). In spectra manager, the spectrum measurement method was used to gather intrinsic spectra. Settings for wavelength 
emission were $300-450 \mathrm{~nm}$ and $280 \mathrm{~nm}$ for excitation. Band widths were set to $5 \mathrm{~nm}$ with a response time of 0.1 second, data pitch at $1 \mathrm{~nm}$, and scanning speed of $500 \mathrm{~nm} / \mathrm{minute}$ and medium sensitivity. A background spectrum was collected using deionized water. This background spectrum was subtracted from each of the treatment spectra prior to reporting peak intensity. All spectra were smoothed using the corrections tabular prior to exporting the data as text. The peak intensity of the relative power, $F$, for each sample is proportional to the level of denaturation.

\subsection{8 $\underline{\mathrm{BCA}}$}

Two $25 \mathrm{~mL}$ aliquots of each treatment sample were added to two $50 \mathrm{~mL}$ centrifuge tubes (Fisher Scientific, Pittsburgh, PA). One of each was adjusted to $\mathrm{pH} 4.6$ with $0.1 \mathrm{~N}$ and $0.01 \mathrm{~N} \mathrm{HCl}$ (Fisher Scientific) using a freshly calibrated hand held $\mathrm{pH}$ Tester 30 (OAKTON Instruments, Veron Hills, IL). Samples that were $\mathrm{pH}$ adjusted and unadjusted were then centrifuged (Beckman Coulter, Brea, CA) for 25 minutes at $1000 \mathrm{x}$ g at $4^{\circ} \mathrm{C}$ and the supernatant was retained. Samples were all diluted to $147 \mu \mathrm{L} / \mathrm{mL}$ in DI, to ensure that the samples were in the working range of $20-2000 \mu \mathrm{g} / \mathrm{mL}$, and mixed for ten seconds on the Vortex Genie 2 (Scientific Industries, Bohemia, NY). A BCA assay kit (Thermo Scientific, New York, NY) was used to determine total protein content in liquid whey samples and adjusted $\mathrm{pH}$ liquid whey samples. BCA standards and working reagents were prepared according to microplate procedure instructions, included with the kit. $25 \mu \mathrm{L}$ of each standard and sample were plated in duplicate on the microplate (PerkinElmer, Waltham, MA). 200uL of the prepared working reagent was then added to each well and mixed on an InnOVA 2000 platform shaker (New Brunswick Scientific) at 55RPM for 30 seconds. The microplate was covered and incubated at $37^{\circ} \mathrm{C}$ in an 
Isotemp Incubator 655D (Fisher Scientific) for thirty minutes, then cooled to room temperature, approximately five minutes. The microplate was read at $562 \mathrm{~nm}$ once cooled to room temperature in a Spectra Max Plus microplate spectrophotometer (Molecular Devices, Sunnyvale, CA) in congruence with Soft-Max Pro software (Meta Imaging Software, Downington, PA). An external standard curve was prepared from absorbance readings of the standards to determine the unknown protein content of each of the samples. DI water was subtracted as background from each sample. Soluble protein for each treatment was expressed as a percentage of total protein as the denaturation measurement.

\subsubsection{Statistical Analysis}

SAS 9.1 statistical software (SAS, Cary, NC) was used for statistical analysis of the data. Statistical code was specifically written to evaluate the major effects of each factor as well as the interaction effects of the two factors as shown in table 3.2. The code was used to analyze the response of denaturation as determined by native PAGE, fluorescence spectroscopy and BCA separately.

\section{Table 3.2 Statistical Analysis of Experiment 1}

\begin{tabular}{|c|c|}
\hline \multicolumn{2}{|c|}{ Experimental Design } \\
\hline Main Effects: & Isolation Method, Heat Treatment \\
\hline $\begin{array}{c}\text { Interaction } \\
\text { Effects: }\end{array}$ & Isolation Method x Heat Treatment \\
\hline Response: & $\begin{array}{c}\text { Denaturation measured by native Polyacrylamide Gel } \\
\text { Electrophoresis, Fluorescence Spectroscopy and Bicinchoninic } \\
\text { Acid Assay }\end{array}$ \\
\hline$n$ (Replicates): & 2 \\
\hline
\end{tabular}

\subsection{Experiment 2}

The experimental series 2 , a partial $2^{2}$ experimental design, which had one factor 
for one of the treatments, was performed in duplicate. These experiments were designed to answer questions that were formulated based on the results from the first experimental design, but with the intent to be able to control all of the processing parameters.

As shown in table 3.3 and figure 3.3, raw milk from the Cal Poly dairy was collected in 10-gallon milk cans after the morning milking and transferred to the DPTC. Next the milk was skimmed and pasteurized in the DPTC Pilot plant. The pasteurized, skim milk was then added to a cheese vat and coagulated with enzyme. Liquid whey was collected and heat treated. Whey was then refrigerated overnight at $3^{\circ} \mathrm{C}$. The next day the liquid whey was concentrated and dried. Spray dried and freeze dried whey powder were reconstituted and analyzed for Solubility, and denaturation using BCA and fluorescence spectroscopy. General linear model, ANOVA was used to statistically analyze the data using Minitab. Specific methodology is described in the following sections.

Table 3.3 Design of Experiment: Experiment 2

\begin{tabular}{|c|c|c|}
\hline Factor & Treatment & Responses \\
\hline \multirow{2}{*}{ Heat Treatment } & Low heat & \begin{tabular}{c} 
Denaturation Measured by: \\
Fluorescence Spectroscopy and \\
\cline { 2 - 2 } Bicinchoninic Acid Assay (BCA)
\end{tabular} \\
\hline \multirow{2}{*}{ Drying Method } & High Heat & Solubility \\
\cline { 2 - 3 } & Spray Dry & Soeze Dry \\
\hline
\end{tabular}


Figure 3.3 Flow Diagram for Experiment 2

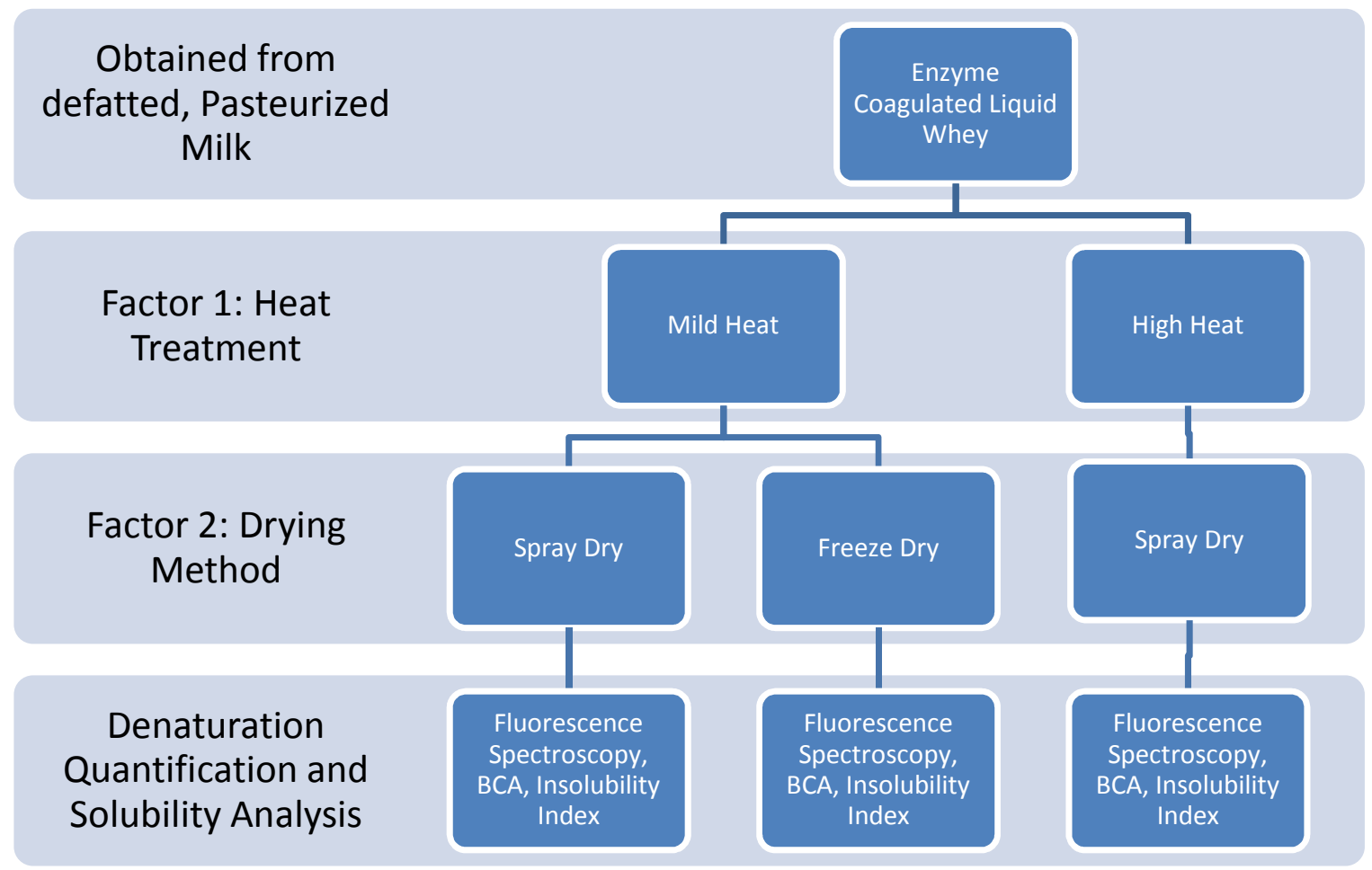

\subsubsection{Whey Manufacture}

Approximately 120 gallons of raw milk from Holstein and Jersey cows was picked up from the Cal Poly Dairy after the morning milking using twelve 10-gallon milk cans. Milk was collected using the provided hosing for the raw milk tank, located in the DPTC clean out of place (COP) station. Using two push carts, the milk was transferred to the DPTC pilot plant. The milk was immediately skimmed using the pilot plant separator (Westflaia, Germany) and batch pasteurized (PMS Processing Machinery \& Supply, Philadelphia, PA) under HTST conditions in the DPTC Pilot Plant.

Figure 3.4 is depicts the process used for whey manufacture. Skim, pasteurized milk was collected into clean, 10 gallon milk cans from the pasteurizer. Pasteurized milk was then transferred to a 150 gallon cheese vat (Kusel Equipment Company, Watertown, WA). Milk was brought up to $30^{\circ} \mathrm{C}$, using the steam jacketed vat, then $100 \mathrm{~mL}$ of $\mathrm{CHY}$ - 
MAX (Chr-Hansen, Milwaukee, WI) was added. After setting for thirty minutes, the curd was cut using vertical and horizontal cheese cutting wires. Whey was drained through a curd separator and pumped through a filter basket using a tri-clover pump into 10 gallon milk cans. Liquid whey was divided into two plots and immediately subjected to heat treatment.

\section{Figure 3.4 Schematic of Whey Manufacture}

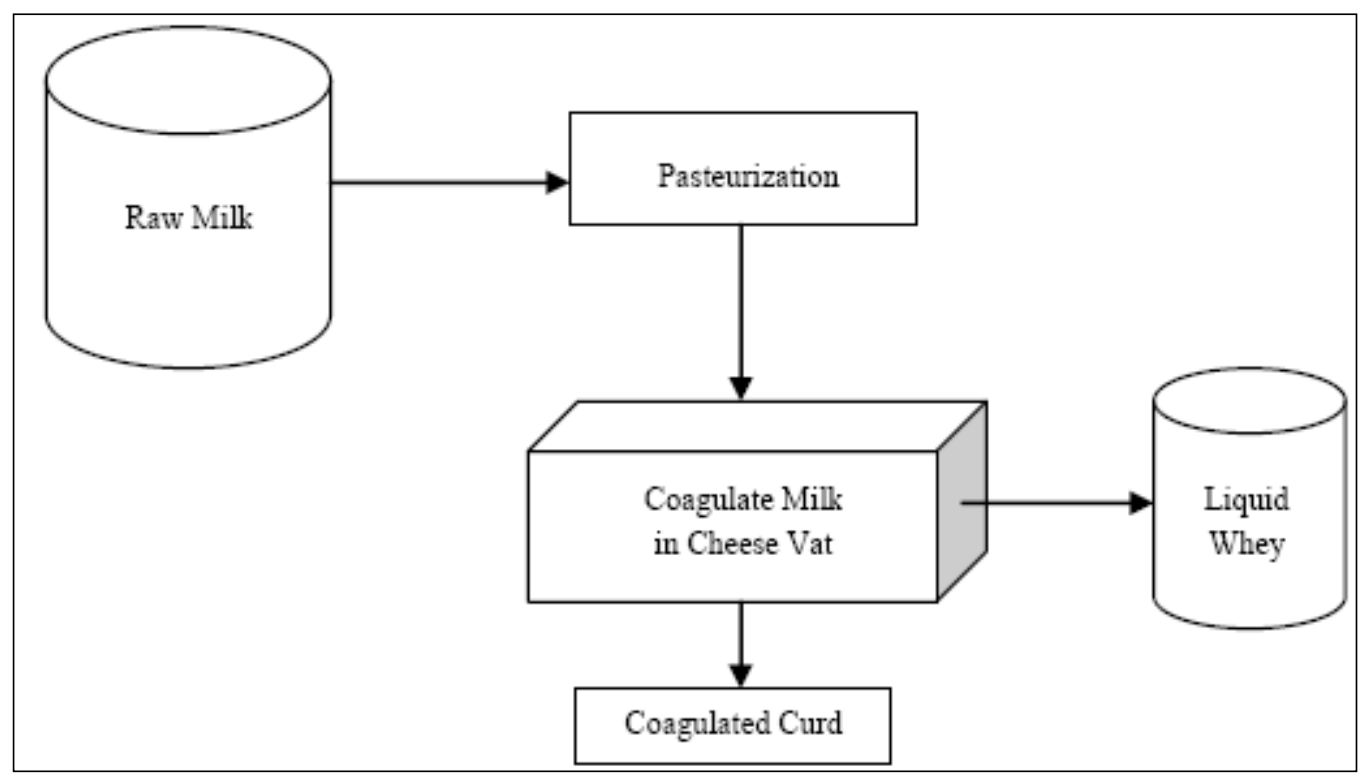

\subsubsection{Heat Treatment}

A MicroThermics UHT/HTST Direct and Indirect Processing System (MicroThermetics, Raleigh, NC) pasteurization unit was used. For a low heat treatment, one plot was treated according to pasteurization parameters, $72^{\circ} \mathrm{C}$ for 15 seconds. The second lot was held at $79.5^{\circ} \mathrm{C}$ for 3 minutes. Heat treated liquid whey was refrigerated at $35^{\circ} \mathrm{C}$ overnight in covered 10 gallon milk cans.

\subsubsection{Powder Manufacture}

Total Solids of the liquid whey samples were analyzed using a Lab Wave 9000 
microwave oven (CEM Service, Matthews, NC). Two square sample pads (CEM \#200150) were placed in the sample compartment and the instrument was zeroed out. Approximately 3 grams of liquid whey was added to the lower pad using a transfer pipette to sandwich between the two pads. The method for cheese whey was selected and power was set to $100 \%$, this took 4 minutes for the weight to stabilize. Total protein analysis was done using BCA, as described in section 3.1.8. Liquid whey was concentrated based on calculations to yield a powder with $35 \%$ protein, assuming the moisture of the finished powder would be approximately 5\%. Concentration was done using a $10 \mathrm{~nm}$ ultrafiltration ceramic membrane in an R-12 Universal Membrane System (GEA, Milwaukee, WI) in the DPTC Pilot Plant.

As shown in Figure 3.5, concentrated liquid whey from the low heat treated whey was divided into two lots prior to drying. One lot of the low heat treated whey and the high heat treated whey were each dried using the Filterlab Spray Dryer (Niro-GEA, Milwaukee, WI), in the Cal Poly Pilot Plant DPTC with an inlet temperature of $88^{\circ} \mathrm{C}$ and outlet temperature of $213^{\circ} \mathrm{C}$ at 400 PSI. The second lot of low heat treated whey was dried using a Ray-1 Vacuum Freeze Dryer (Niro-GEA) in the Food Science Department Pilot Plant. Parameters for the freeze dryer were set to have a layer thickness of 30$35 \mathrm{~mm}$, frozen product temperature of $-25^{\circ} \mathrm{C}$, product set point of $45^{\circ} \mathrm{C}$, heating plate set point of $130^{\circ} \mathrm{C}$ and vacuum set point of $35 \mathrm{mbar}$. One hour of constant weight indicated that the freeze drying process was complete and prompted the freeze dryer to shut down automatically. This took approximately 22 hours. 
Figure 3.5 Schematic for Whey Powder Manufacture

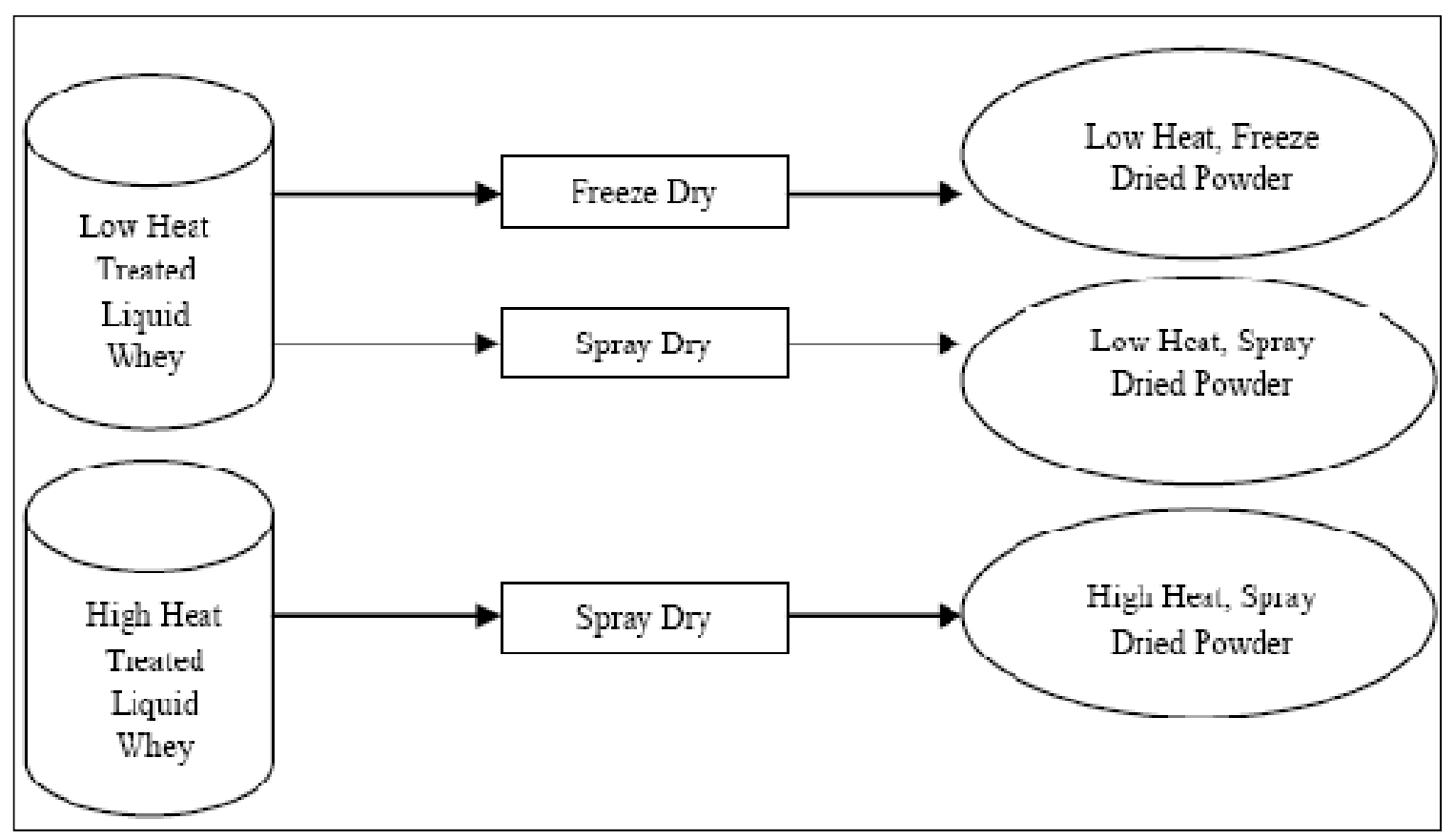

\subsubsection{Solubility}

An IsoTemp 210 water bath (Fisher Scientific, Pittsburgh, PA) was set to $24^{\circ} \mathrm{C}$ and a $500 \mathrm{~mL}$ beaker of DI water was brought to that temperature. An aliquot of 3 grams of each whey protein powder were weighed out on an Explorer analytical scale (Ohaus, Pine Brook, NJ). An aliquot of $50 \mathrm{~mL}$ of DI water at $24^{\circ} \mathrm{C}$ was added to a Commercial 7Speed blender (Waring, Torrington, CT). The whey powder was then added to the blender and mixed for exactly 90 seconds on speed setting 1 , as shown in figure 3.6. The entire mixture was transferred to a $100 \mathrm{~mL}$ beaker for holding period of fifteen minutes; any clumps were removed from the blender with a metal spatula. After holding, the mixtures were added to a conical centrifuge tubes and centrifuged (Beckman Coulter, Brea, CA) at $980 \mathrm{RPM}$ for 5 minutes at $4^{\circ} \mathrm{C}$. The supernatant liquid was immediately siphoned off of the sediment, leaving liquid $5 \mathrm{~mL}$ above the sediment using a $10 \mathrm{~mL}$ 
disposable pipette (Fisher Scientific). 50mL DI water was added to the centrifuge tube and the sediment was dislodged and mixed with a metal spatula. The mixture was again centrifuged at $980 \mathrm{RPM}$ for 5 minutes at $4^{\circ} \mathrm{C}$. Holding the conical centrifuge tube on a flat surface, the sediment level was read by eyesight to the nearest graduation on the centrifuge tube and recorded.

\section{Figure 3.6 Solubility Procedure}

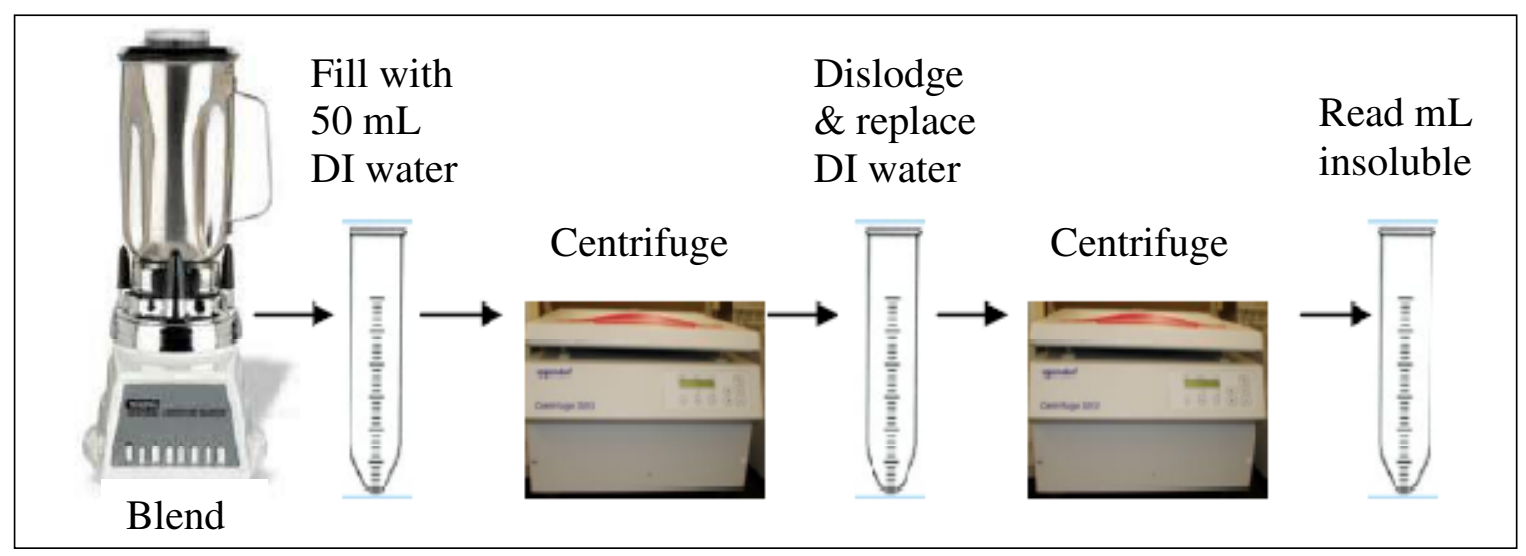

\subsubsection{Fluorescence Spectroscopy}

Samples were reconstituted for one hour prior to testing for fluorescence spectroscopy to yield the same concentration as used in the solubility test. This was done by measuring $1.5 \mathrm{~g}$ of whey powder to $25 \mathrm{~mL}$ of DI water into a $150 \mathrm{~mL}$ beaker and mixing with a stir bar and RO-10 Power (IKA, Wilmington, NC) stir plate on level 5. The procedure for fluorescence spectroscopy was then followed as described in section

\subsection{7.}

\subsection{6 $\underline{\mathrm{BCA}}$}

Samples were reconstituted as described in section 3.2.4 for one hour prior to testing for fluorescence spectroscopy to yield the same concentration as used in the solubility. The procedure for BCA soluble protein was then followed as described in 
section 3.1.8.

\subsubsection{Statistical Analysis}

Minitab 15.0 statistical software (Minitab, INC. State College, PA) was used to analyze the data as shown in figure 3.6. The General Linear Model method of ANOVA was employed. In the case of variance, Tukey's test was used to determine differences between treatments.

Table 3.4 Statistical Analysis of Experiment 2

\begin{tabular}{|c|c|}
\hline \multicolumn{2}{|c|}{ Experimental Design } \\
\hline Main Effects: & Low Heat, Spray Dry; Low Heat, Freeze Dry; High Heat, Spray Dry \\
\hline Response: & $\begin{array}{c}\text { Denaturation measured by Fluorescence Spectroscopy and } \\
\text { Bicinchoninic Acid Assay, Functional Solubility }\end{array}$ \\
\hline$n$ (Replicates): & 2 \\
\hline
\end{tabular}




\subsection{Results and Discussion}

\subsection{Preliminary Research}

\subsubsection{Experiment 1}

The purpose of the first experiment was to gather data on analytical methods used to quantify denaturation at a broad level which would then feed into a more narrowed scope of denaturation at the commercial product level and its relationship to functionality. An experiment was designed in effort to gather insight into more than one research objective: characterizing truly native structure in whey protein, quantification of denaturation of whey protein and correlation of multiple analytical methods of quantifying whey protein denaturation.

The experimental design, shown in Table 4.1 below, included three split-plot designs with three levels for each of three factors yielding nine treatment combinations was chosen because it would allow for exploration of each of the research objectives simultaneously. Minimal processing was desired to truly control the experiment; therefore all analysis was done on liquid whey.

\subsubsection{Factors of Experiment 1}

The first factor of the experimental design was isolation method of whey. As whey is naturally a by-product of cheese manufacture, one level for isolation would simulate cheese whey. A bench top enzyme coagulation method to generate liquid whey was developed. Current interest in microfiltration prompted a pilot plant level membrane filtration method of isolation. Although it is not economically feasible at this time, high rotation frequency-long time centrifugal isolation was a selected method as it a very 
gentle method that should not alter the structure of the whey proteins.

Table 4.1Exerimental Design by Response for Experiment 1

\begin{tabular}{|c|c|c|}
\hline \multicolumn{3}{|c|}{ Design 1} \\
\hline Factor & Level & Response \\
\hline \multirow{3}{*}{ Isolation Method } & Membrane Filtration & \multirow{6}{*}{$\begin{array}{l}\text { Whey Protein Band Intensity } \\
\text { Measured by Native } \\
\text { Polyacrylamide Gel } \\
\text { Electrophoresis (PAGE) }\end{array}$} \\
\hline & Enzyme Coagulation & \\
\hline & Centrifugal & \\
\hline \multirow{3}{*}{ Heat Treatment } & No Heat & \\
\hline & Mild Heat & \\
\hline & High Heat & \\
\hline \multicolumn{3}{|c|}{ Design 2} \\
\hline Factor & Level & Response \\
\hline \multirow{3}{*}{ Isolation Method } & Membrane Filtration & \multirow{6}{*}{$\begin{array}{l}\text { Tryptophan Fluorescence } \\
\text { Intensity Measured by } \\
\text { Fluorescence Spectroscopy }\end{array}$} \\
\hline & Enzyme Coagulation & \\
\hline & Centrifugal & \\
\hline \multirow{3}{*}{ Heat Treatment } & No Heat & \\
\hline & Mild Heat & \\
\hline & High Heat & \\
\hline \multicolumn{3}{|c|}{ Design 3} \\
\hline Factor & Level & Response \\
\hline \multirow{3}{*}{ Isolation Method } & Membrane Filtration & \multirow{6}{*}{$\begin{array}{c}\text { \% Soluble Protein at } \mathrm{pH} 4.6 \\
\text { measured by Bicinchoninic Acid } \\
\text { Assay (BCA) }\end{array}$} \\
\hline & Enzyme Coagulation & \\
\hline & Centrifugal & \\
\hline \multirow{3}{*}{ Heat Treatment } & No Heat & \\
\hline & Mild Heat & \\
\hline & High Heat & \\
\hline
\end{tabular}

To quantify denaturation, a factor that would induce denaturation was selected for the second factor of the split plot. Heat was chosen for the treatment factor as it is known to induce denaturation, controllable and easily measured (Singh and Havea, 2003). Furthermore, a no heat treatment was necessary for the purpose of obtaining a most undenatured sample; a mild heat and high heat treatment were used to simulate 
pasteurization and further heat processes.

\subsubsection{Responses of Experiment 1}

Fluorescence spectroscopy, BCA and PAGE were chosen as methods for quantification of protein denaturation because they are representative of different structural analysis, time efficient for purpose of specific research and industrially economical.

\subsubsection{Materials and Methods of Method Development for Experiment 1}

Preliminary research was conducted to determine specific methodology for all levels for each factor of the experiment. Obtaining the milk from the Cal Poly creamery was not expected to have any implications, therefore all preliminary research was done with store bought whole and skim milk.

\subsubsection{Manufacture of Liquid Whey}

Laboratory skimming of milk was done by centrifugation at $1000 \mathrm{x} \mathrm{g}$ for 30 minutes at $4^{\circ} \mathrm{C}$ (Law and Leaver, 2000). This method for skimming milk worked well and did not require modification. Microfiltration of skim milk can be used to permeate whey proteins (Heino et al., 2007). Using a $0.1 \mu \mathrm{m}$ zirconium oxide membrane (GEA, Milwaukee, Wi), isolation was achieved. Cheese whey can be simulated through use of enzyme coagulation of casein at the laboratory level (Fagan et al., 2007). A simple bench top enzymatic coagulation of casein in mimic of cheese whey production was performed to isolate liquid whey. This was successfully done by following time temperature coagulation variables for cheese making. Review of literature revealed that ultracentrifugation as a method to separate casein from whey can be done utilizing 
centrifugal force of 100,000 x g for 1 hour (Larson et al., 2006). Using the available ultracentrifuge and running at maximum force, ranging the time from 1 to 5 hours, it was found that $62,000 \mathrm{xg}$ for 3 hours was a sufficient force and force for isolation.

\subsubsection{Heat Treatment}

Three levels of heat were chosen to reflect minimal processing, High Temperature Short Time pasteurization and a higher heat treatment (FDA, 2010). Review of literature on the thermal effects on denaturation found that researchers have studied a range of $50^{\circ} \mathrm{C}-150^{\circ} \mathrm{C}$ over a holding time range of 15 seconds to 30 minutes, while most of the lower temperatures $\left(<80^{\circ} \mathrm{C}\right)$ were studied with longer holding times (minutes) and most of the higher temperatures $\left(>80^{\circ} \mathrm{C}\right)$ were held for shorter holding times (seconds) (Ardö et al., 1999; Agrawal et al., 2008; Galani and Apenten, 1999; Havea et al., 2001; Marangoni et al., 2000). For this experiment, it was decided that a heat treatment that mimicked HTST denaturation and a significantly higher heat treatment that would be representative of heat endured through normal processing conditions, were lacking. When conducting preliminary research on heat treatment of the samples, exposure time and holding time were reviewed. Exposure time is more equal when applying the heat treatment due to varying time taken to reach the temperature of the treatments. However, holding time provides adequate exposure and is relative to industrial practices, therefore was the chosen method.

\subsubsection{Analytical Quantification of Whey Protein Denaturation}

Method development for fluorescence spectroscopy included selecting fluorescence method, band width, excitement and emission wavelengths and scanning speed. Many researchers have used this method for intrinsic fluorescence with excitation 
at $280 \mathrm{~nm}$ and scanning emission from 300-450 nm (Anand et al., 1998; Enomoto et al., 2008; Marangoni et al., 2000). Peak emission for whey protein is usually at 340nm (Anand et al., 1998). Background needed to be subtracted from the peak. Researchers have used solutions of calcium chloride and lactose solutions for background collection (Marangoni et al., 2000). It is possible that the three methods of isolation may have removed lactose and minerals at varying levels, so it was decided that plain DI water should be used background collection.

BCA was used as a method of measuring total and soluble protein. Although Kjeldahl Nitrogen and Whey Protein Nitrogen Index are approved methods, BCA was selected because these methods are regarded as tedious and time consuming and low reliability, respectively (Manji and Kakuda, 1987). In this method, liquid whey samples were adjusted to $\mathrm{pH} 4.6$ to precipitate denatured whey proteins (Law and Leaver, 2000; Parris and Baginski, 1991) . Conducting BCA on the unadjusted sample provides a total protein and the adjusted sample provides soluble, native protein. A dilution found to deliver liquid whey samples in a working concentration was used for all samples.

The SDS-PAGE method used is described in Current Protocols in Food Analytical Chemistry (Whrolstand et al., 2001). For PAGE under native conditions omitting SDS, b-mercaptan and heat from SDS-PAGE protocol is necessary (Chen et al., 2005). The original idea was to quantify native as a percentage of total protein using a laser densitometry. However, it was determined unreliable methodology due to inherent differences between gels. Theoretically, completely denatured proteins become agglomerated and are not able to enter the gel. Therefore, total whey protein under native PAGE conditions was the selected response for the method. Dilution rates, loading 
amounts, and voltage of running the gels were all parameters that were experimented with in preliminary research.

\subsubsection{Materials and Methods of Method Development for Experiment 2}

The objectives of the second experiment were formulated based on result from experiment 1 as well as original objectives not addressed in the experiment 1 . To be discussed in detail in section 4.2, we found in experiment 1 that there is not a significant difference between no heat a high heat treatment and that fluorescence spectroscopy and BCA on $\mathrm{pH} 4.6$ solubility are adequate methods for quantifying denaturation.

Table 4.2 outlines the experimental design for experiment 2. The factors for the second experiment were heat treatment, which we expected to have an effect based on results from experiment 1 , and drying method. Objectives for experiment 2 were to confirm heat treatment effects from experiment 1 , evaluate the effect of drying method and evaluate of the relationship between denaturation and solubility. Preliminary laboratory analysis was conducted on WPC 35 samples for BCA, Fluorescence spectroscopy and solubility as there was only need for one preliminary pilot plant trial to obtain powdered whey.

Skimming and pasteurization processes were purposefully left out in preliminary trials in attempt to achieve a no treatment whey that would be representative of industrially produced whey and to have a no heat treatment to compare to experiment 1 , respectively. This led to a higher fat content in the total solids of the liquid whey than was desired. It was determined that for the experiment a skimming step would be needed. Decreasing the fat in the total solids for the experimental run was also expected to increase the protein content of total solids, which was lower than expected in the 
preliminary trial. Extreme caution was exercised when working with raw milk in the cheese room during the trial, which was not being used by other manufacturers. However, it was not feasible to run the experiment in entirety while other DPTC researchers and the Cal Poly creamery would not be using the cheese room so it was decided too risky to have raw product in there while commercial and research cheese were being produced, thus the milk would need to be pasteurized prior to coagulation.

\section{Table 4.2 Experimental Design by Response for Experiment 2}

\begin{tabular}{|c|c|c|}
\hline \multicolumn{3}{|c|}{ Design 1} \\
\hline Factor & Level & Responses \\
\hline $\begin{array}{l}\text { Heat Treatment, Drying } \\
\text { Method }\end{array}$ & $\begin{array}{c}\text { Low heat, Spray Dry Low } \\
\text { Heat, Freeze Dry, } \\
\text { High Heat, Spray Dry }\end{array}$ & $\begin{array}{l}\text { Tryptophan Fluorescent } \\
\text { Intensity Measured by } \\
\text { Fluorescence } \\
\text { Spectroscopy }\end{array}$ \\
\hline \multicolumn{3}{|c|}{ Design 2} \\
\hline $\begin{array}{l}\text { Heat Treatment, Drying } \\
\text { Method }\end{array}$ & $\begin{array}{c}\text { Low heat, Spray Dry Low } \\
\text { Heat, Freeze Dry, } \\
\text { High Heat, Spray Dry }\end{array}$ & $\begin{array}{l}\text { \% Soluble Protein at } \mathrm{pH} \\
4.6 \text { measured by } \\
\text { Bicinchoninic Acid Assay } \\
\text { (BCA) }\end{array}$ \\
\hline \multicolumn{3}{|c|}{ Design 3} \\
\hline $\begin{array}{c}\text { Heat Treatment, Drying } \\
\text { Method }\end{array}$ & $\begin{array}{c}\text { Low heat, Spray Dry Low } \\
\text { Heat, Freeze Dry, } \\
\text { High Heat, Spray Dry }\end{array}$ & $\begin{array}{l}\text { mL Insoluble measured by } \\
\text { GEA Insolubility Index }\end{array}$ \\
\hline
\end{tabular}

In the preliminary trial, liquid whey was frozen in half gallon aliquots in sheets created by gallon size Ziploc freezer bags prior to drying for freeze drying. After 14 hours in the drying chamber, the probes were no longer detecting a difference in temperature for the product. Although the weight was still dropping at very slow rates, it was assumed the freeze drying process was complete and the equipment was manually 
shut down. Upon removing the trays from the dryer, a thin layer of ice that was indeed still in the core of the sheet rapidly melting, destroying the powder. As the freeze dryer requires less volume and minimal preparation, further method development was possible using store bought skim milk. Freezing methods, including use of ice cube trays and various sizes of Ziploc bags with different volumes, as well as plate temperatures during drying were experimented with. It was determined that filling a quart size Ziploc bag one quarter full prior to freezing created a thin sheet of frozen material that was conducive for freeze drying. A temperature that should not impart a true heat treatment to the powder, but decreased the drying time substantially was found.

As BCA and fluorescence spectroscopy methods had already been refined in experiment one, only reconstitution and dilution rates needed to be evaluated during preliminary research for this experiment. It was decided to reconstitute the powders at the same level as required for the solubility method. This then required further dilution for both BCA and fluorescence spectroscopy.

There are several official methods for determining whey and other dairy powders protein solubility based on physical and chemical solubility (Morr et al., 1985; Anandharamakrishnan et al., 2008; Heino et al., 2007; Diez et al., 2008). The Determination of Solubility Index of the American Dairy Institute and the Insolubility Index provided by GEA-Niro were both experimented with in preliminary research (ADPI, 2009; GEA, 2006). Both methods are based on the principal of reconstituting powder by rigorous mixing followed by centrifugation and measurement of sedimentation. There are subtle differences in the methods; the only difference of any significance is the GEA-Niro method includes a vacuum to remove liquid while the 
ADPI method requires a siphon tube. Solubility of whey protein was determined using a slightly modified combination of the two methods.

\subsection{Experiment 1}

\subsubsection{Characterization of Native Whey Protein}

Structural differences indicative of denaturation were evident for main effects, isolation method and heat treatment, and interaction effects, isolation by heat treatment using fluorescence spectroscopy. Therefore, this method was determined effective at characterizing native structure.

Table 4.3 summarizes the relationships, the interaction effects for all of the nine treatment combinations: Centrifugal Isolation, No Heat $(\mathrm{CN})$; Centrifugal Isolation, Mild Heat (CM); Centrifugal Isolation, High Heat $(\mathrm{CH})$; Enzyme Isolation, No Heat (EN); Enzyme Isolation, Mild Heat (EM); Enzyme Isolation, High Heat (EH), Filtration Isolation, No Heat (FN); Filtration Isolation, Mild Heat (FM), Filtration Isolation, High Heat $(\mathrm{FH})$. Interaction treatments that are bold and italicized indicate relationships where statistical difference exists while the non-bold relationships indicate no statistical difference between the relationships (P-value <0.01). Notice that the treatment, centrifugal isolation, no heat was statistically different from all other treatments, these are highlighted. The relationships of the treatment combinations are shown in Figure 4.1 with error bars to include the $95 \%$ confidence interval of the mean. This supports the hypothesis that Centrifugal Isolation without heat treatment is significantly more native in structure than all other treatment combinations and can be used as a control for determining denaturation. 
Table 4.3 Statistical Differences for Interaction Effects by Fluorescence Spectroscopy

\begin{tabular}{|c|c|c|}
\hline Treatment 1 & Treatment 2 & P-Value \\
\hline $\mathrm{CH}$ & $\mathrm{CM}$ & $<0.0001$ \\
\hline $\mathrm{CH}$ & $C N$ & $<0.0001$ \\
\hline $\mathrm{CH}$ & $\mathrm{EH}$ & 0.00340 \\
\hline $\mathrm{CH}$ & EM & 0.00060 \\
\hline $\mathrm{CH}$ & $\mathrm{EN}$ & $<0.0001$ \\
\hline $\mathrm{CH}$ & $\mathrm{FH}$ & 0.02570 \\
\hline $\mathrm{CH}$ & $\mathrm{FN}$ & $<0.0001$ \\
\hline CM & $C N$ & 0.00020 \\
\hline $\mathrm{CM}$ & $\mathrm{EH}$ & $<0.0001$ \\
\hline $\mathrm{CM}$ & EM & 0.04310 \\
\hline $\mathrm{CM}$ & $\mathrm{FH}$ & $<0.0001$ \\
\hline $\mathrm{CM}$ & $\mathrm{FM}$ & 0.00100 \\
\hline CN & $\boldsymbol{E H}$ & $<0.0001$ \\
\hline$C N$ & $E M$ & $<0.0001$ \\
\hline$C N$ & $E N$ & 0.00600 \\
\hline$C N$ & $F H$ & $<0.0001$ \\
\hline$C N$ & $F M$ & $<0.0001$ \\
\hline CN & $F N$ & 0.00040 \\
\hline $\boldsymbol{E H}$ & $E M$ & $<0.0001$ \\
\hline$E H$ & $E N$ & $<0.0001$ \\
\hline $\boldsymbol{E H}$ & $F H$ & 0.00060 \\
\hline $\boldsymbol{E H}$ & $F M$ & $<0.0001$ \\
\hline$E H$ & $F H$ & $<0.0001$ \\
\hline$E M$ & $F H$ & 0.00320 \\
\hline$E N$ & $F H$ & 0.00010 \\
\hline$E N$ & $F M$ & 0.00440 \\
\hline $\boldsymbol{F H}$ & $F M$ & 0.04400 \\
\hline$F H$ & $F N$ & $<0.0001$ \\
\hline$F M$ & $F N$ & 0.00090 \\
\hline
\end{tabular}

Key: CN-Centrifugal Isolation, No Heat; CM-Centrifugal Isolation, Mild Heat; $\mathrm{CH}-$ Centrifugal Isolation, High Heat; EN-Enzyme Isolation, No Heat; EM-Enzyme Isolation, Mild Heat; EH-Enzyme Isolation, High Heat; FN-Filtration Isolation, No Heat; FMFiltration Isolation, Mild Heat; FH-Filtration Isolation, High Heat 
Figure 4.1 Peak Fluorescence Intensities by Treatment

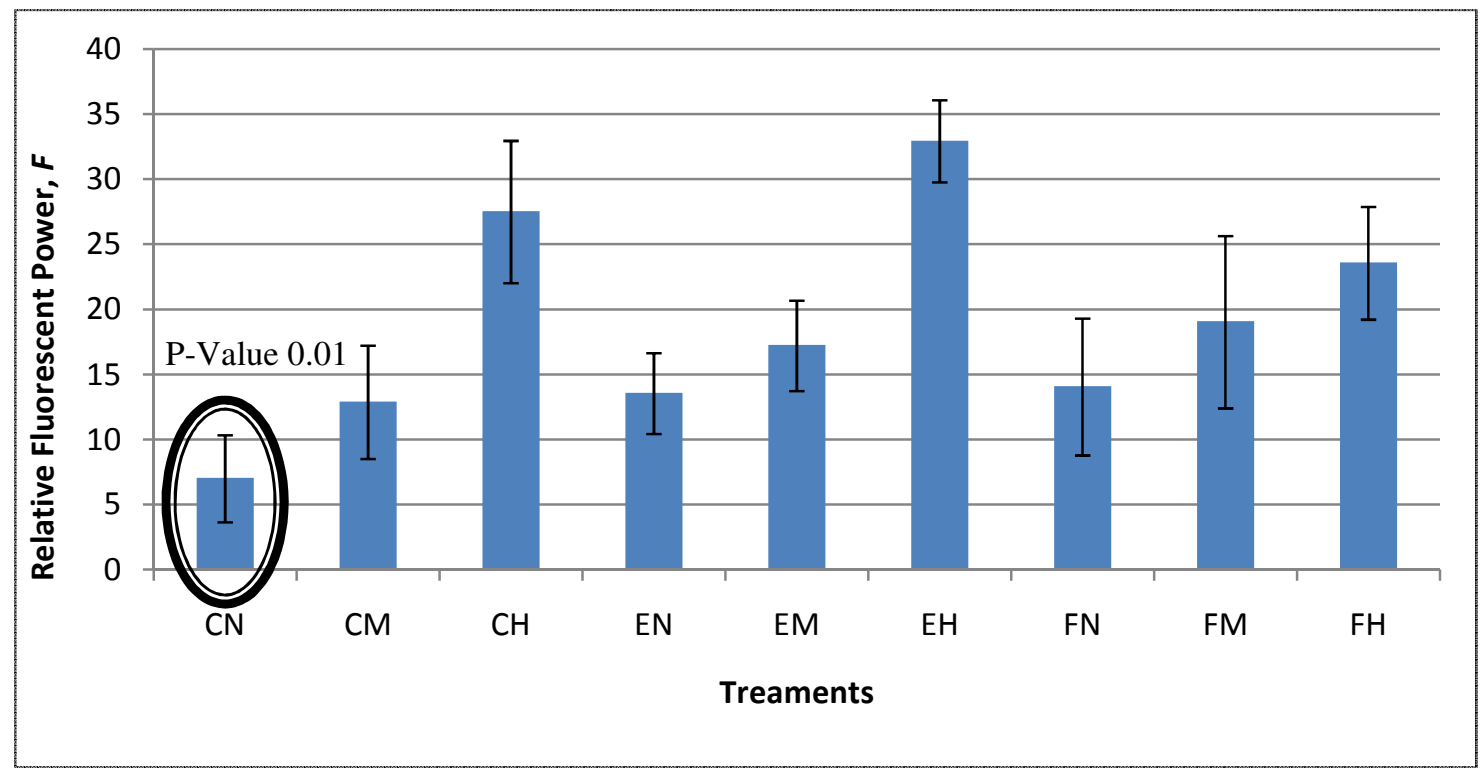

Key for Treatment: CN-Centrifugal Isolation, No Heat; CM-Centrifugal Isolation, Mild Heat; CH-Centrifugal Isolation, High Heat; EN-Enzyme Isolation, No Heat; EM-Enzyme Isolation, Mild Heat; EH-Enzyme Isolation, High Heat; FN-Filtration Isolation, No Heat; FM-Filtration Isolation, Mild Heat; FH-Filtration Isolation, High Heat. Error Bars include the 95\% Confidence Interval.

\subsubsection{Denaturation Characterized by Native PAGE in Whey}

No differences were detected for main effects for of the isolation method or heat treatment main effects or for the interaction effects using native PAGE for analysis with p-values of $0.086,0.8628$ and 0.7563 , respectively. While there truly is no difference for the main effect of heat or for the interaction of isolation and heat, there may be a practical difference due to the main effect of isolation method. In this experiment, there were two replications.

The least significant difference for a p-value of 0.01 for isolation method is 28943.9 ODU (optical density units). The actual differences between for isolation methods were 4635 ODU between centrifuge and enzyme, 20535 ODU between centrifuge and filtration and 15900 ODU between enzyme and filtration. The least 
significant difference for heat treatment is 19889.7 ODU. The actual differences between heat treatments were 2721 ODU between no heat and low heat, 695 ODU between low heat and high heat and 3416 ODU between low heat and high heat.

The sum of the average densities for the protein bands correlated with $\alpha$-la and $\beta$ $\lg$ are shown in figures 4.2 and 4.3, respectively. Although not statistically significant at the $p-<0.01$ level, the filtration isolation method appears to have considerably less "native" whey protein than the enzyme and centrifugal isolation methods. However, this is likely due to a lower total protein content in the whey obtained by centrifugal isolation than due a higher degree of isolation. In several studies when native PAGE has been used characterize whey protein denaturation, it is generally a part of a larger scope of gel electrophoresis methods including SDS-PAGE under reducing and/or non-reducing conditions and 2-dimentional PAGE, which allows for subjective comparisons between native and total protein content (Hong and Creamer, 2002; Considine et al., 2007; Chen et al., 2005; Enomoto et al., 2008; Havea et al., 2001; Anand et al., 1998). As previously discussed, the inherent differences from gel to gel and denaturing effects of other PAGE methods make it unrealistic to make such comparisons quantitatively.

Although quantitative analysis of denaturation using PAGE under native conditions is theoretically possible by analyzing the density of the soluble "undenatured" whey protein bands on the gel, native PAGE was not found to be a successful method for differentiating denaturation of whey protein due to isolation method or heat treatment with statistical significance in this experiment. Band densities of the corresponding whey proteins were too variable to yield reproducible results with statistical significance for quantifying denaturation. However, qualitative analysis of denaturation is possible with 
native PAGE. Aggregates of denatured proteins are too large to enter the gel and remain in the sample well. This can clearly be seen in the gels that as the protein band densities decrease in intensity, the density of the aggregate in the sample well increases in intensity and will be discussed further in section 4.2.5.1. Furthermore, when native PAGE has been used to characterize whey protein denaturation, it is generally a part of a larger scope of gel electrophoresis methods including SDS-PAGE under reducing and/or nonreducing conditions and 2-dimentionol PAGE (Hong and Creamer, 2002; Considine et al., 2007; Chen et al., 2005; Enomoto et al., 2008; Havea et al., 2001; Anand et al., 1998).

Figure 4.2 Densities of Whey Proteins Bands by Isolation Method Measured by Native PAGE

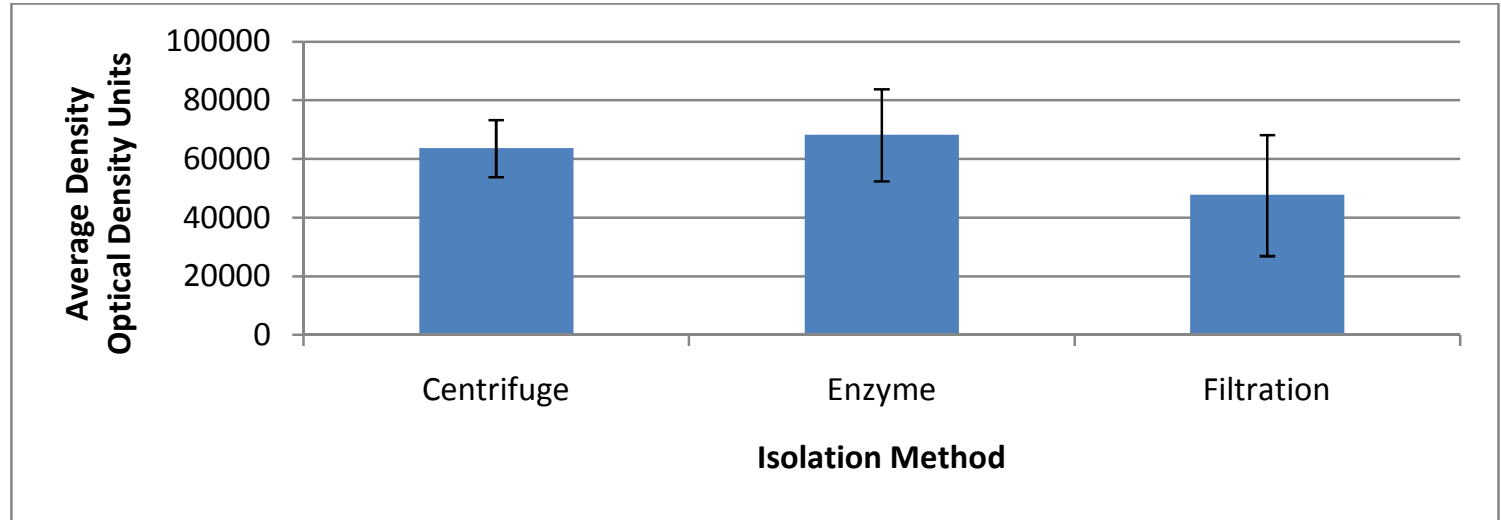

Error bars include the $95 \%$ Confidence Interval.

Figure 4.3 Density of Whey Proteins Bands by Heat Treatment Measured by Native PAGE

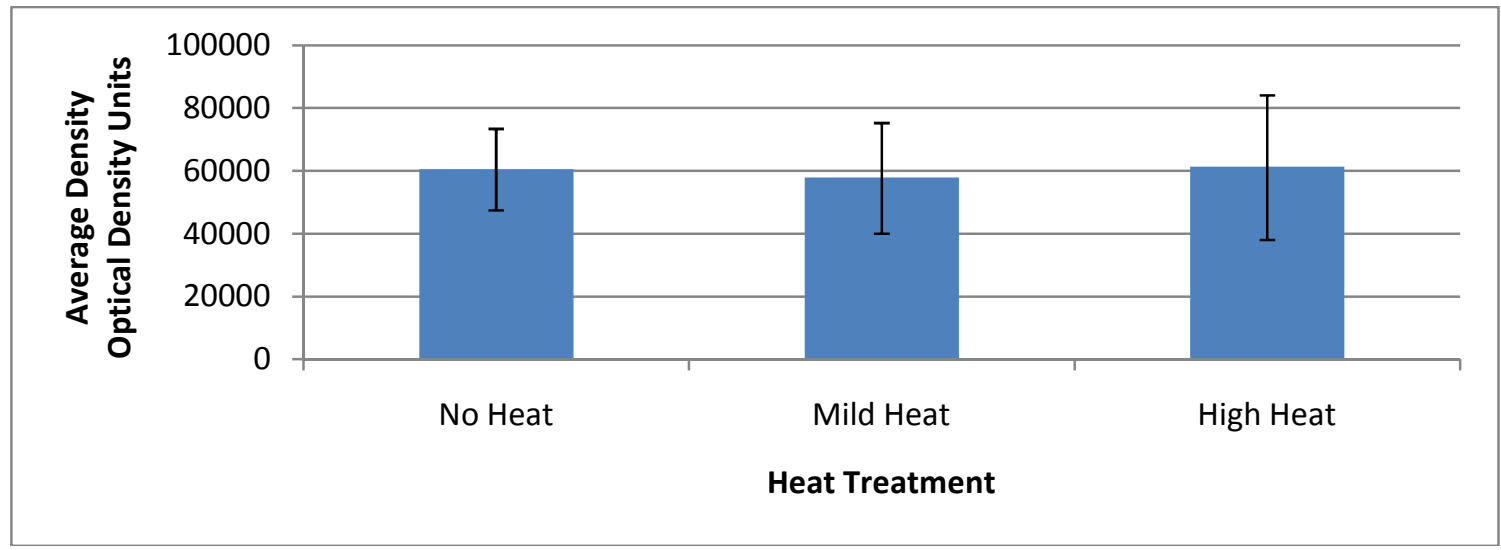

Error bars include the $95 \%$ Confidence Interval. 


\subsubsection{Denaturation Characterized by Fluorescence Spectroscopy in}

Whey

Statistical analysis indicates differences in structural properties due to isolation method and heat treatment, as well as the interaction of isolation and method, when using the analytical method of fluorescence spectroscopy with p-values of $0.014,<0.001$ and 0.001, respectively. In isolation method there are differences between centrifuge and enzyme (p-value 0.0061), centrifuge and filtration (p-value 0.0182), and no difference between enzyme and filtration (p-value 0.3908). For heat method there are differences between high heat and mild heat ( $\mathrm{p}$-value $<0.001)$, high heat and low heat (p-value $<0.001)$ and mild heat and low heat (p-value <0.001). As denaturation increases, the fluorescent peak intensity increases then decrease upon aggregation, this trend expectation is shown in figure 4.4. The peak intensities for isolation method and heat treatment are shown in figures 4.5 and 4.6, respectively.

Figure 4.4 Expected Trend for Response of Fluorescence Spectroscopy to Denaturation

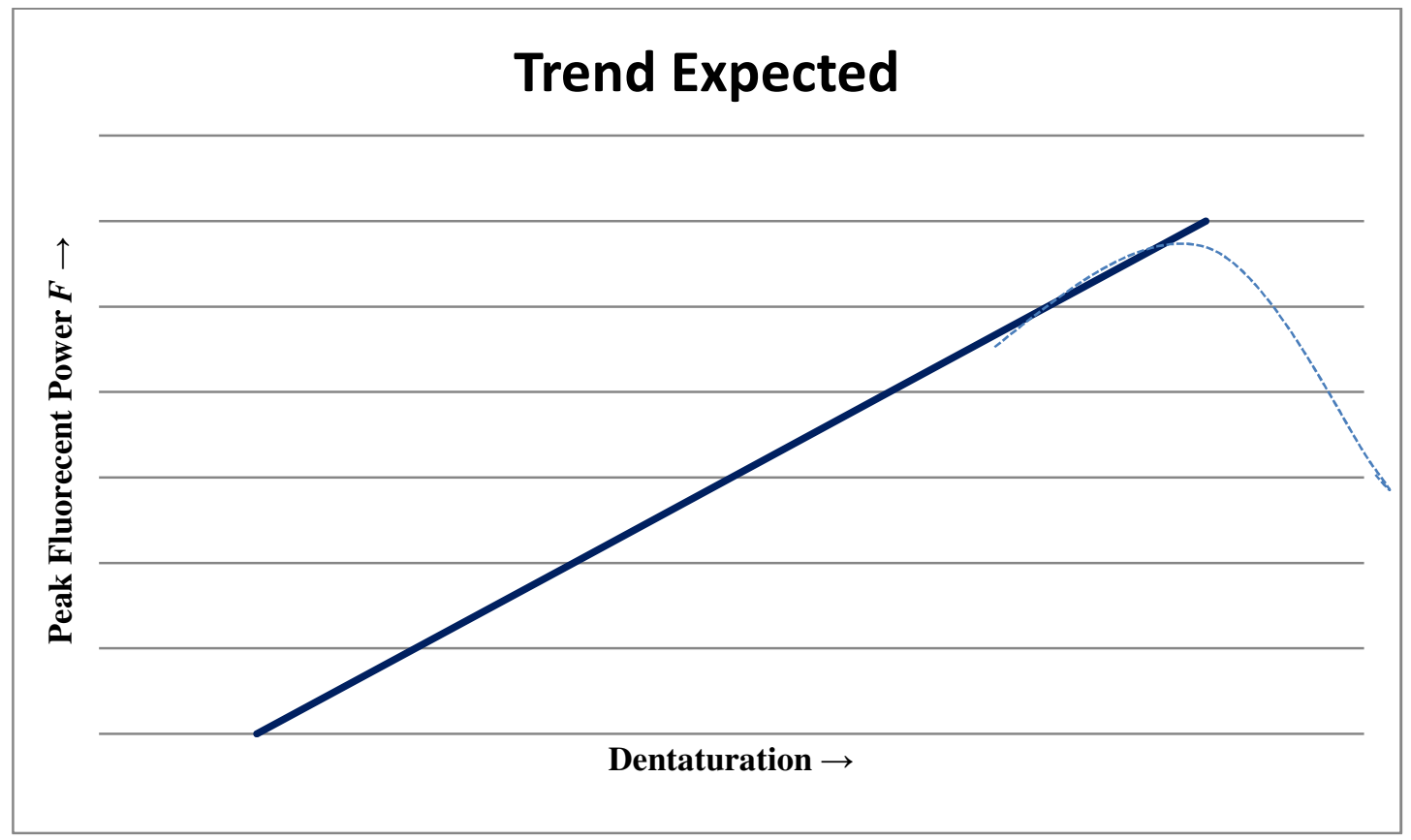


Figure 4.5 Peak Intensity of Whey Proteins by Isolation Method Measured by Fluorescence Spectroscopy

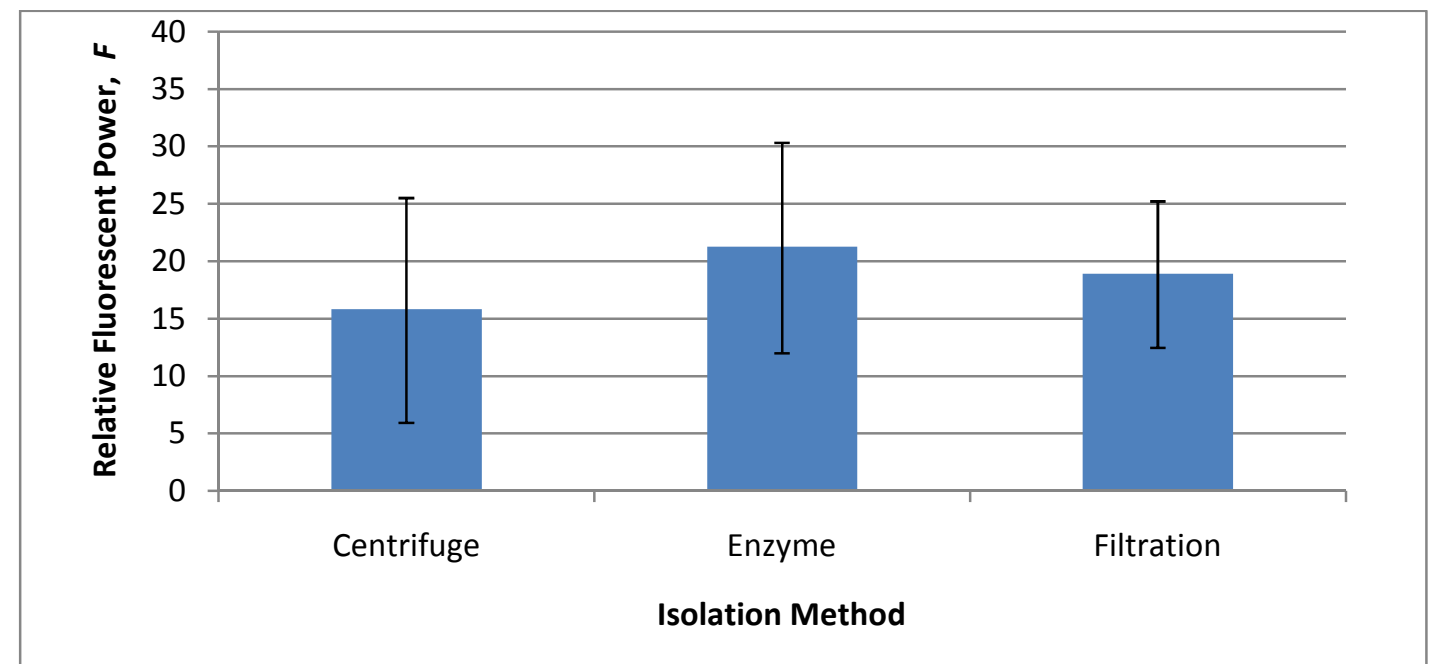

Error bars include the $95 \%$ Confidence Interval

Figure 4.6 Peak Intensity of Whey Proteins by Heat Treatment Measured by Fluorescence Spectroscopy

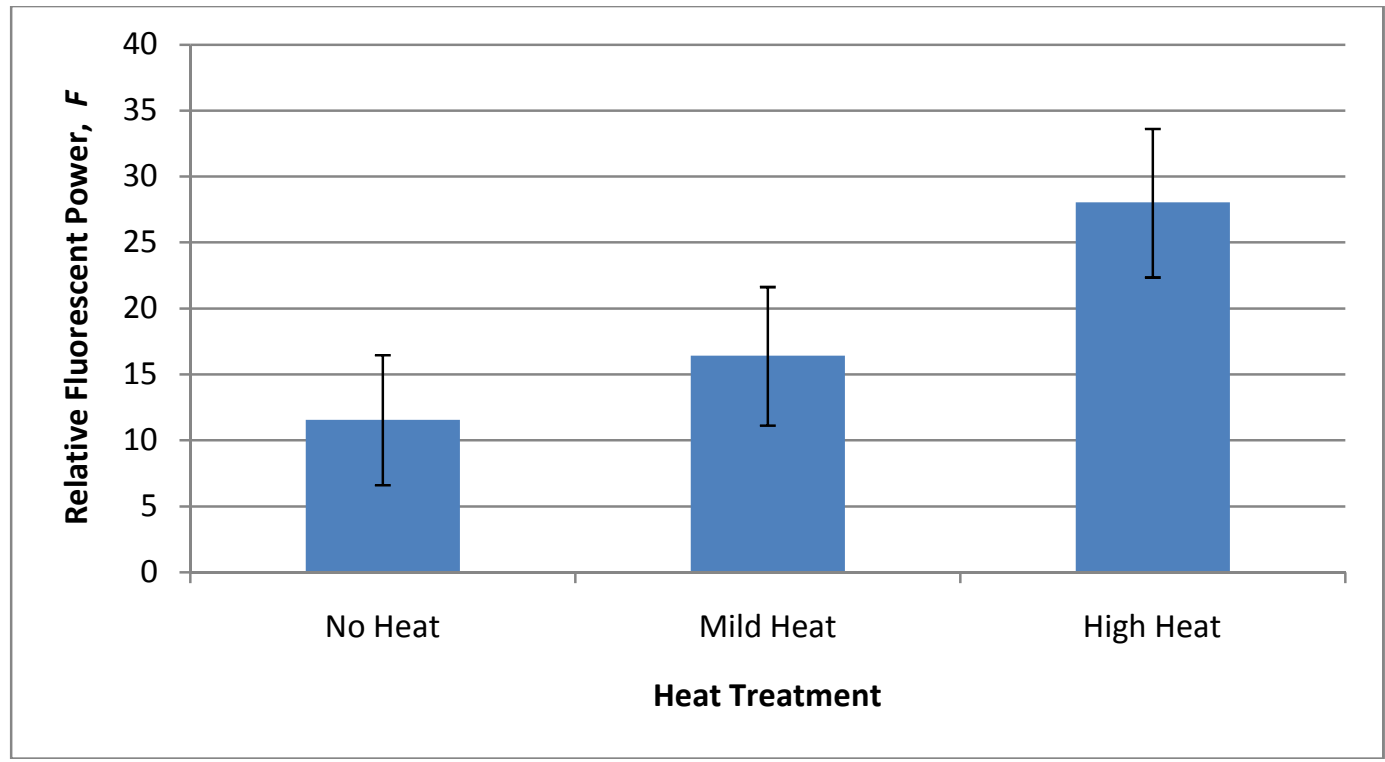

Error bars include the $95 \%$ Confidence Interval

Fluorescence spectroscopy should be considered for research evaluating the effect of $\mathrm{pH}$ on denaturation. Many methods that have been used to quantify denaturation rely on the basis of precipitating denatured whey protein at $\mathrm{pH}$ 4.6. Use of fluorescence spectroscopy as an alternative method would allow researchers to explore a wider range 
of $\mathrm{pH}$ values. Law and Leaver, (2000), for example, studied the $\mathrm{pH}$ range of 5.2-8.8 in their study on whey protein denaturation. As whey protein is commonly used in low $\mathrm{pH}$ applications, conducting a similar study on the effect of $\mathrm{pH}$ in a range that is more industrially applicable is possible using fluorescence spectroscopy.

In this research, it was found that intrinsic fluorescent intensity increases as a positive correlation to the denaturation of whey proteins. Anand et al. (1998) suggested that fluorescent intensity increases as conformational changes increase exposure of tryptophan and tyrosine, until all such residues are exposed and further conformational changes do not result in an increase in fluorescent intensity. They found this ceiling to be at $79.4^{\circ} \mathrm{C}$ for 3 minutes, which falls between the two heat treatments used in the current research. In another study, Marangoni et al. (2000) found that heat induced protein unfolding, 30 minutes at $80^{\circ} \mathrm{C}$, produced a $4.5 \mathrm{~nm}$ red-shift in the intrinsic tryptophan emission wavelength as well as a significant decrease in maximum intensity. This is thought to be attributed to a significant loss of tertiary structure resulting in a molten globule structure. These conflicting results suggest that fluorescence intensity may be successful at characterizing the proposed two-step denaturation process of unfolding followed by aggregation of whey protein. Hypothetically, undenatured whey proteins should have low fluorescence intensity due to the embedded tryptophan residues in the tertiary structure, but increases in intensity as the proteins unfold exposing tryptophan residues completing the first proposed step of denaturation. Aggregation, the second proposed step of denaturation, results in hiding tryptophan residues as the proteins form a mass. The result of the second step is loss of fluorescence intensity. This explains why there is inconsistency in the literature regarding the subject, the fluorescence can either 
increase or decrease as denaturation increases, depending on the initial and final degree of denaturation.

\subsubsection{Denaturation Characterized by BCA in Whey}

Denatured protein measured by BCA soluble protein found no difference in denaturation due to isolation method (p-value 0.1307 ), but showed a difference due to heat ( $\mathrm{p}$-value $<0.001)$ and no difference for the combined treatment for isolation, heat treatment (p-value 0.3911). Comparisons can be seen below in figures 4.6, isolation, and 4.7, heat. There is a difference between high heat and mild heat (p-value 0.0001) and between high heat and no heat ( $\mathrm{p}$-value $<0.0001)$. There is no difference between mild heat and no heat (p-value 0.1431). The least significant difference for isolation method is 9.77. The actual differences for isolation method were 6.86 between centrifuge and enzyme, 3.54 between centrifuge and filtration and 3.32 between enzyme and filtration.

The expected trend for the response of BCA to denaturation is shown in figure 4.7. Native protein, characterized by the percent soluble at $\mathrm{pH} 4.6$ at $20^{\circ} \mathrm{C}$, for isolation method and heat treatment are shown in figures 4.8 and 4.9 , respectively.

Figure 4.7 Expected Trend for Response of $\mathrm{pH} 4.6$ solubility measured by BCA to Denaturation

\section{Expected Trend}

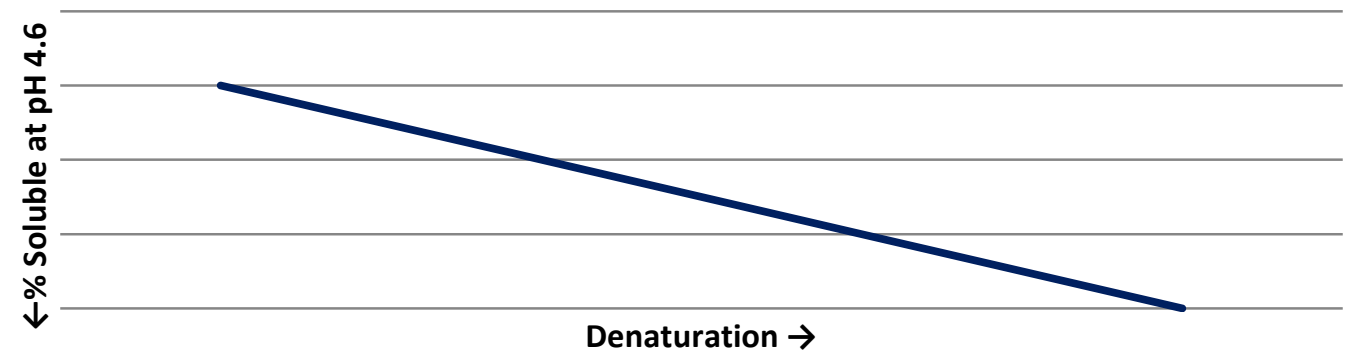


Figure 4.8 Soluble Protein by Isolation Method by BCA

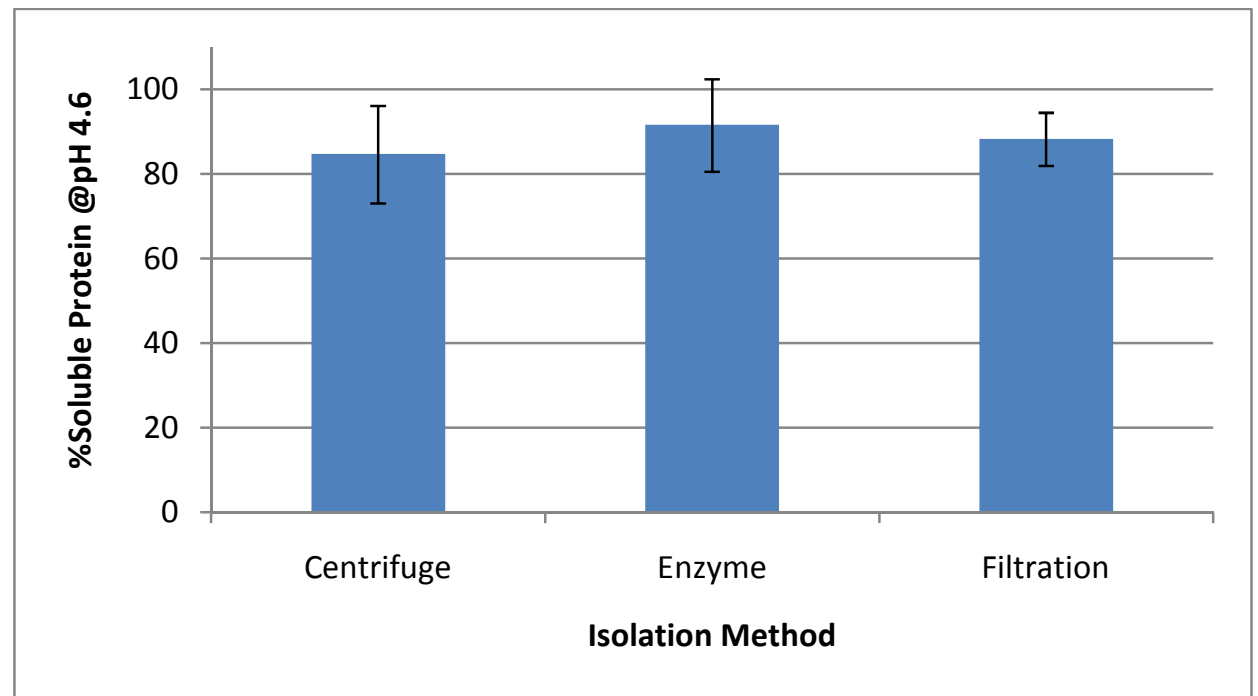

Error bars include the 95\% Confidence Interval

Figure 4.9 Soluble Protein by Heat Treatment by BCA

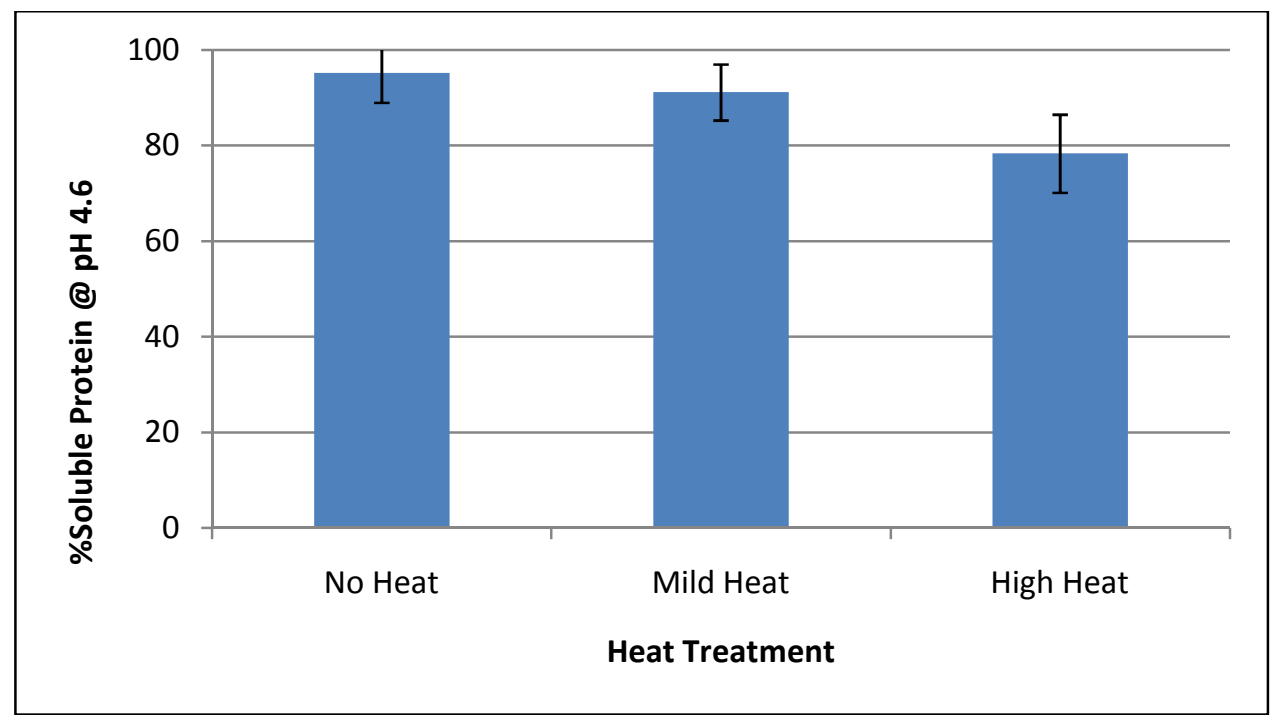

Error bars include the 95\% Confidence Interval

The BCA method was used to quantify the loss of solubility at the isoelecric point of the protein as a measure of denaturation. BCA is a quick crude method that was found to be able to measure the extent of denaturation based on the loss of solubility at $\mathrm{pH}$ 4.6. This principal was first notably used in the late 1970's when Harwalkar (1980) found that heating $\beta$-lg at $90^{\circ} \mathrm{C}$ for $0.1-30$ minutes resulted in varying degrees in loss of solubility at 
$\mathrm{pH} 4.6$ by measuring absorbance by ultraviolet spectrophotometry of the supernatant. Law and Leaver (2000) used gel permeation FPLC to measure denaturation due to effects of heat and $\mathrm{pH}$ utilizing the same basis of loss of solubility at $\mathrm{pH}$ 4.6. This method of quantifying the loss $\mathrm{pH} 4.6$ solubility has since been used for measuring denaturation using Kjeldahl (Anand et al., 1998) HPLC (Ju et al., 1997) and Capillary Electrophoresis (Ardö et al., 1999). Extensive review of literature found that this principal of precipitating denatured proteins at $\mathrm{pH} 4.6$ then measuring the total and soluble protein has not been widely used with the BCA assay. In the current study, this method was sensitive enough to distinguish levels of denaturation based on the main effects of isolation method and heat treatment, as well as on the interaction effects of isolation method and heat treatment in liquid whey.

\subsubsection{Effects of Experimental Factors on Denaturation in Whey}

\subsubsection{Effect of Heat Treatment}

In this current research it was found that there is no difference between no heat and low heat treatments, however there is a difference between no heat and high heat and between low heat and high heat. This provides further evidence that there is not a significant denaturation effect of pasteurizing whey proteins under HTST standards as it is in aggreement with another recent study done denaturation of whey, where researchers also found fluorescence intensity is not significantly different in the case of raw versus pasteurized whey protein (Pulgarin et al., 2005).

In the present study, while not statistically significant, it is visually apparent that the band intensities for each treatment containing high heat $\left(85^{\circ} \mathrm{C}\right)$ are less intense than those of no or low heat treatment as seen qualitatively in Figure 4.10. Anand et al. (1998) 
found that the band intensities of $\alpha$-la and $\beta$-lg decreased significantly between $79.5^{\circ} \mathrm{C}$ and $82.2^{\circ} \mathrm{C}$. In a study of using $\beta$-lg as a thermal marker for processed milk, $80^{\circ} \mathrm{C}$ for 4 minutes was found to be the minimum treatment requirement for the complete denaturation of $\beta$-lg (Chen et al., 2005). Another study done by Mousavi et al. (2008) of thermal effects on $\beta$-lg under native PAGE conditions indicates that thermal denaturation begins at $75^{\circ} \mathrm{C}$. However, the holding time for each temperature was twenty minutes. The results presented had much longer holding time parameters for the heat treatments. Therefore, the results they experienced had more to do with the time/temperature relationship than the temperature alone.

Figure 4.10 Native PAGE gel

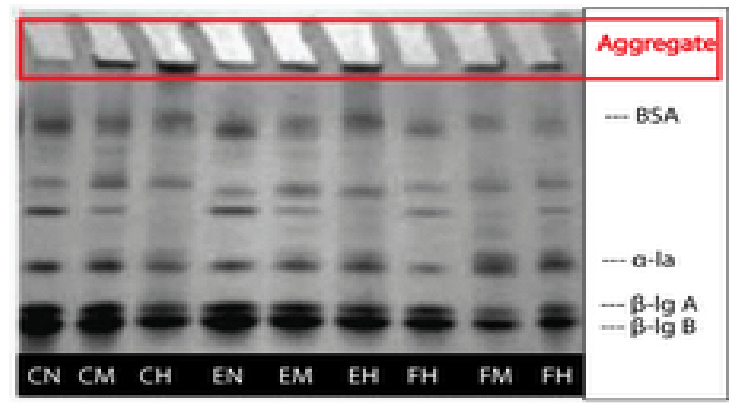

Key: CN-Centrifugal Isolation, No Heat; CM-Centrifugal Isolation, Mild Heat; $\mathrm{CH}-$ Centrifugal Isolation, High Heat; EN-Enzyme Isolation, No Heat; EM-Enzyme Isolation, Mild Heat; EH-Enzyme Isolation, High Heat; FN-Filtration Isolation, No Heat; FMFiltration Isolation, Mild Heat; FH-Filtration Isolation, High Heat

While extensive work has been done on the effect of heat treatment on whey protein structures, there is a lot that remains unknown regarding structural changes that occur. Hong and Creamer (2002) studied the effect of heat treatment on protein structure of bovine $\alpha-1 \mathrm{la}$ and $\beta-\lg$ using native PAGE. They found that a heat treatment of $85^{\circ} \mathrm{C}$ for 10 minutes was not substantially different from the control for $\alpha$-la, while $\beta$-lg was $80 \%$ denatured under the same heat treatment compared to the control. Using native PAGE, Havea et al. (2001) found that heating a mixture of $\alpha$-la and $\beta$-lg to $75^{\circ} \mathrm{C}$ for 1 minute 
decreased the intensity of the corresponding bands, however the drastic reduction of intensity of the bands accompanied by a large mass of aggregate in the loading well occurred at $75^{\circ} \mathrm{C}$ for 6 minutes. By selecting a known processing parameter that is used industrially for HTST pasteurization and a higher heat treatment that proteins may experience under normal processing conditions, insight has been attained as to what the structural differences are in terms of realistic circumstances of different heat treatments commonly exposed to whey proteins. Thus, normal conditions of HTST pasteurization do not have a significant impact on thermal denaturation of whey proteins, however a moderately higher heat treatment does. This is important for production of whey powder and whey powder applications as there is evidence that the minimal treatment required is near the threshold for native structure and should be monitored.

\subsubsection{Effect of Isolation Method}

To date, there has not been much research done on how the isolation method affects denaturation of whey protein. This can mostly be attributed to the fact that whey is a known byproduct of cheese making; therefore most of commercial whey is cheese whey. As membrane technology is a relatively new method for isolating whey protein, little research has been done on structural comparisons of whey proteins obtained from cheese whey. Currently, there is a large amount of research being done on microfiltration systems due to interests in isolating whey prior to cheese making and isolating casein for manufacture of casein isolates (Hernandez and Harte, 2009). As mentioned previously, centrifugal isolation of whey protein is a method commonly used at the lab scale, however not industrially feasible, and little work has been devoted to exploring structural changes that occur during such a method for isolation. Assuming that there will soon be 
industrial applications and process improvements to make centrifugal and enzyme isolation methods economical, the current research has evaluated the effect of isolation method on denaturation, which has not notably been done previously. In this research, there was found to be no difference between enzyme and filtration methods of isolation by fluorescence spectroscopy. This is interesting because there is a lot of thought that microfiltration is a less intrusive method of isolation for whey proteins, yet this research is not supportive of such. There is a statistically significant difference between centrifugal and enzyme isolations and centrifugal and filtration isolations, shown in figure 4.5. Focus on development of centrifugal isolation technology as an alternative to isolating whey proteins is warranted based on these findings.

\subsection{Experiment 2}

\subsubsection{Denaturation in Whey Powder}

Native PAGE was determined to be more useful for qualitative analysis, the second experiment employed BCA and fluorescence spectroscopy for quantitative analysis of denaturation. Also, as it was found in the first experiment that there was no difference between the no heat and low heat treatments, the low heat treatment for experiment two was assumed to have the same characteristics as a no heat treatment. In the second experiment, which had fewer treatments combinations, BCA and fluorescence spectroscopy correlated well for determining the order for the degree denaturation for each treatment. Both methods yield results that the low heat, freeze dry and low heat, spray dry treatments were no different in terms of denaturation and both retained more native structure than the high heat, spray dry treatment. This is indicative that the heat treatment has a greater effect on whey protein denaturation than drying method. 
Although this study found that there was not a difference in denaturation for freeze drying versus spray drying at a low heat level, further research on this topic with higher levels of heat may be warranted, as there is a lot of industry speculation that powders processed by freeze drying differ in terms of functionality form those processed by spray drying.

\subsubsection{Effect of Treatment}

As there had been a difference between heat treatments established in the first experiment the second experiment set out to study the effect of drying method. It was found that there is a difference between low heat, spray dry and high heat, spray dry as well as between low heats, freeze dry and high heat, spray dry. This suggests that the heat treatment has a greater effect on denaturation than drying method as there was no difference between low heat, freeze dry treatment and low heat, spray dry treatment for denaturation.

\subsubsection{Denaturation Characterized by Fluorescence Spectroscopy in Whey Powder}

Statistical analysis of protein structural differences using fluorescence spectroscopy indicates there are differences between the treatments studied: Low Heat,

Freeze Dry; low heat, spray dry and high heat, spray dry (p-value 0.007). Turkey's test was run to determine where differences were and found that there are differences between low heat, spray dry and high heat, spray dry as well as low heat, freeze dry and high heat, spray dry (p-value 0.05), shown in figure 4.11.

Figure 4.11 Peak intensity of Treated Whey Protein Powder by Fluorescence Spectroscopy 


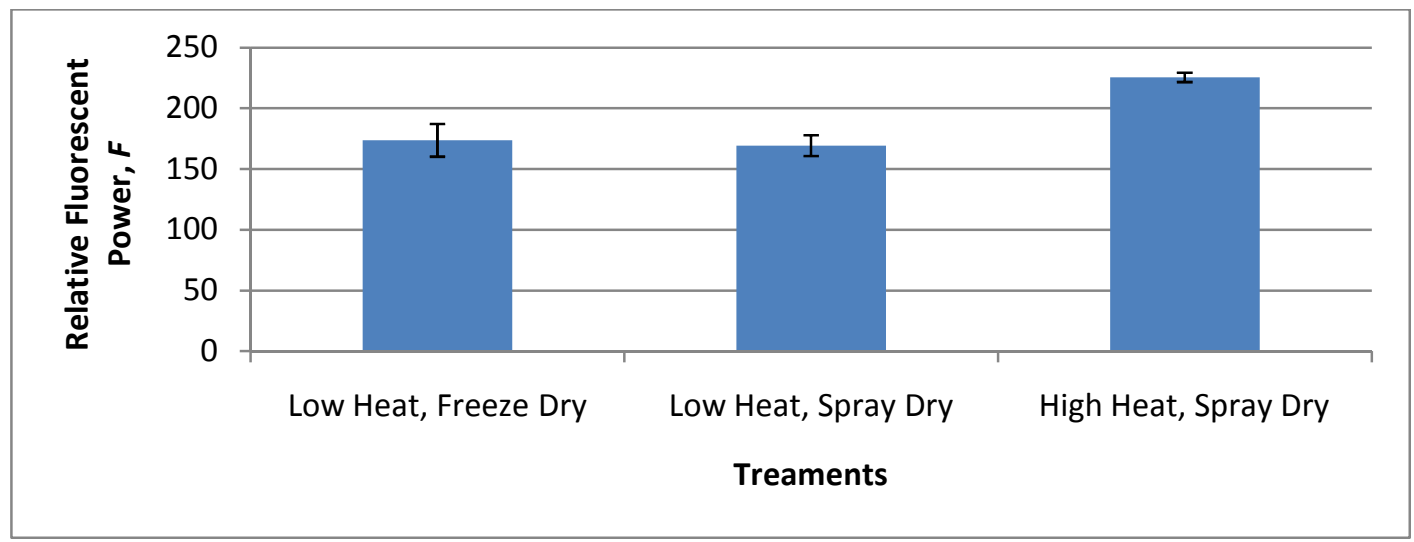

Error bars include the $95 \%$ Confidence Interval of the average value.

\subsubsection{Denaturation Characterized by Bicinchonic Acid Asay in Whey Powder}

Differences were detected using BCA to monitor change in soluble protein concentration due to treatment ( $\mathrm{p}$-value $<0.001$ ). Tukey's paired comparison test shows the differences being between low heat, spray dry and high heat, spray dry as well as low heat, freeze dry and high heat, spray dry (p-value 0.05). These relationships are depicted in figure 4.12 .

Figure 4.12 Protein of Treated Whey Protein Powder by BCA

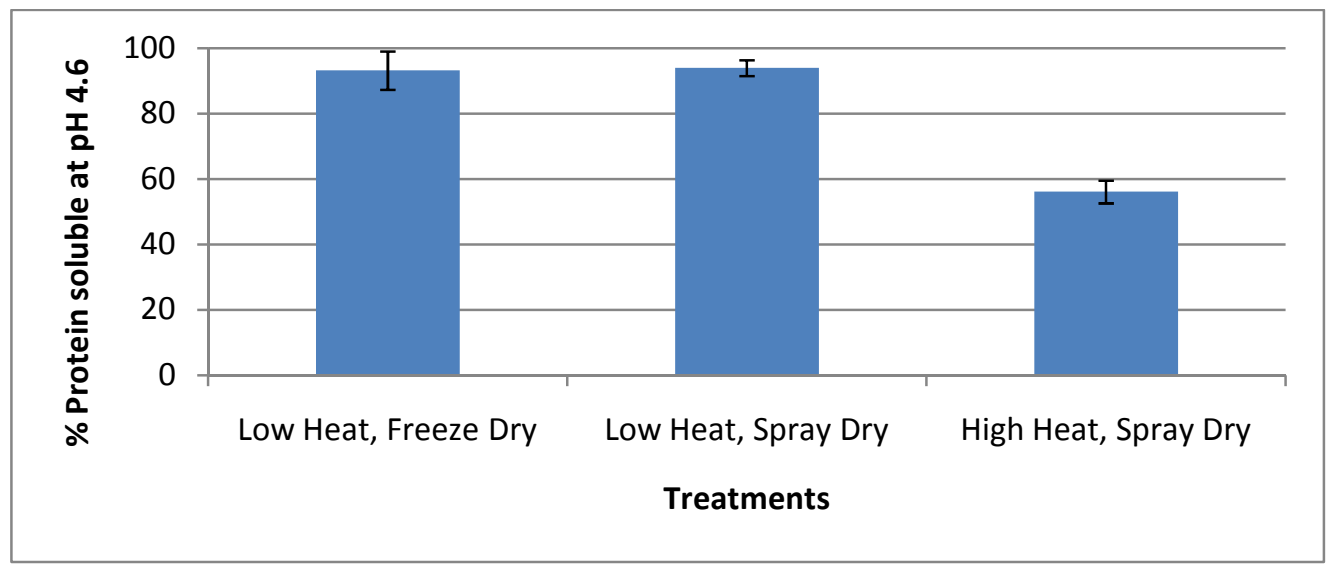

Error bars include the $95 \%$ Confidence Interval of the average value.

\subsubsection{Solubility of Whey Protein Powders}


Differences were detected when monitoring physical protein solubility due to treatment ( $\mathrm{p}$-value $<0.022$ ). Tukey's paired comparison test shows the differences being between low heat, spray dry and low heat, freeze dry as well as low heat, freeze dry and high heat, spray dry (p-value 0.05), shown in figure 4.13.

\section{Figure 4.13 Protein Insolubility due to Treatment}

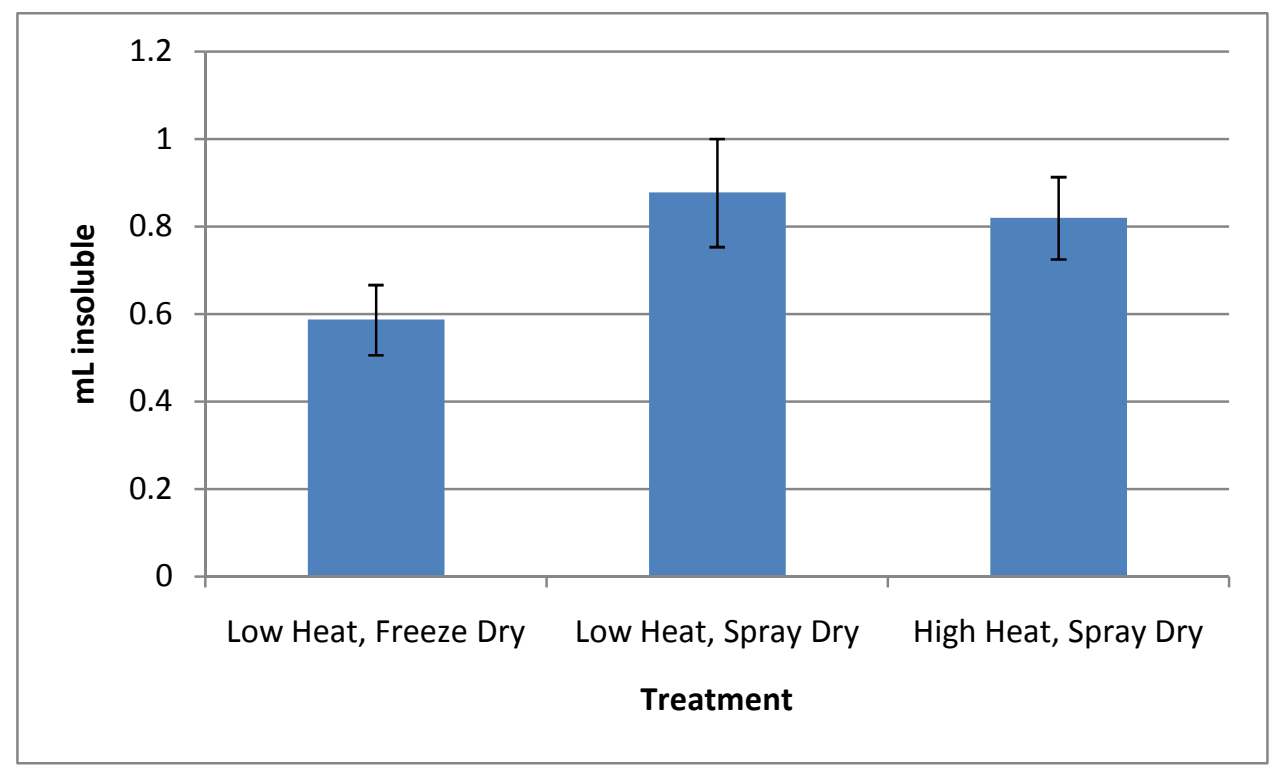

Error bars include the $95 \%$ Confidence Interval of the average value

There was found to be a difference between low heat, freeze dry and low heat, spray dry as well as low heat, freeze dry and high heat, spray dry treatments $(\mathrm{p}<0.01)$ in terms of protein solubility.

Figure 4.14 offers a visual comparison of the insolubility of each of the 3 powders. The rate limiting factor for solubility when producing powder appears to be drying method. As shown above in figure $4.14 \mathrm{~b}$ and $4.14 \mathrm{c}$, the sediment of insoluble matter is higher for the samples that were spray dried, compared to freeze dried, figure 4.14a.

Figure 4.14 Whey Protein Solubility 


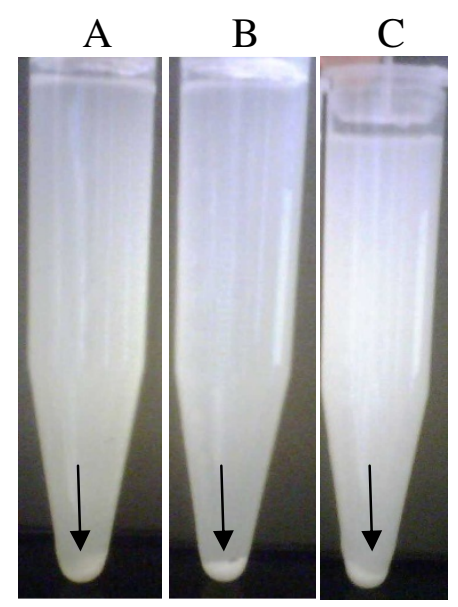
A. Low Heat, Freeze Dry
B. Low Heat, Spray Dry
C. High Heat, Spray Dry

As many researchers have had difficulty obtaining reproducible results for protein solubility, (Morr et al., 1985) set out to develop a standardized food protein solubility procedure. They studied micro-Kjeldahl and biuret methods as alternatives to commonly used nitrogen solubility index procedure. While the study concluded that their microKjeldahl procedure should be used as the reference method for determining protein solubility, researchers found that the difficulty in obtaining such reproducible data can be attributed to the inherent complexity of food protein as well as differences of analytical methods among laboratories. (Morr et al., 1985). Pelegrine and Gasparetto (2005) used this method to evaluate whey protein solubility as a function of temperature and $\mathrm{pH}$. They found that at neutral, unadjusted $\mathrm{pH}$ whey protein solubility decreases significantly beginning at $40^{\circ} \mathrm{C}$. As that temperature is well below the temperatures used in the experiment in evaluation, this suggests a possible explanation that a plateau for heat treatment had been achieved at temperatures lower than those applied.

In a recent study, BCA was used to measure soluble protein of variously treated whey protein samples. The study evaluated the effects of high pressure, ultrasound and 
tribomechanical activation, finding that high pressure was the only treatment to significantly reduce solubility using this method of analysis. Although current pasteurization requirements impart an element of heat to all milk products, the purpose of the research was to study the influences of alternative processing techniques as there is demand for reducing thermal treatment load to whey protein products (Kresic et al., 2008). It would have been beneficial to included heat in this study as a level for the effect of pasteurization as a control for current practices.

\subsubsection{Relationship between Solubility Results and Denaturation Results}

Analytical methods detect denaturation differences due to heat treatment, whil Solubility was dependent on drying method. However, there was a correlation of denaturation and solubility for low heat freeze, dried powder and high heat, spay dried powder. For these two powders, denaturation and solubility were inversely related, as expected.

\subsection{Significance of Research for Scientific Community and Dairy Industry}

The knowledge gained from the research done provides insight to the effects of whey protein isolation method and heat treatment on whey protein denaturation. Furthermore, a method of centrifugal isolation of raw whey, free of any processing conditions which may subject denaturation, was defined as a useful control as a "native" sample. To my knowledge, the effect of isolation method on denaturation of whey protein has not been studied, thus findings that the effect of isolation has on denaturation of whey proteins decreases in order among centrifugation $<$ membrane filtration < enzyme, has significant value. The effect of traditional HTST versus a moderately higher heat treatment on whey protein denaturation were determined to be that traditional HTST 
parameters do not impart significant denaturation compared to no heat, however the higher heat treatment of $85^{\circ} \mathrm{C}$ for 3 minutes has a statistically and practically significant effect on denaturation. This supports previous findings that normal HTST processing parameters do no impart significant thermal denaturation to whey proteins (Pulgarin et al., 2005).

Two methods capable of quantifying denaturation were identified. Fluorescence spectroscopy and BCA soluble protein at $\mathrm{pH} 4.6$ are robust, relatively inexpensive methods that require minimal sample preparation and have a short analysis time, making them industrially promising techniques.

Although the role of denaturation in bioactivity was not an objective in the current research, the possibility of such a relationship with denaturation is important because of the amount of interest and research being done regarding bioactivity of whey proteins and their derivatives. Hydrolysis, denaturation at the primary structure level, of macropeptides in whey proteins is necessary to yield bioactivity (Korhonen and PihlantoLeppala, 2002; Ko and Kwak, 2009; Madureira et al., 2010).

Akbache et al. (2009) recently studied the use of membrane processing to concentrate TGF- $\beta 2$ and IGF-I from bovine milk and whey, two bioactive peptides. In this work, they found that ultrafiltration and diafiltration concentration of whey obtained from microfiltration of milk can potentially be used to produce growth factors extracts with high contents in TGF- $\beta 2$ and low contents in IGF-I. This work also demonstrates the potential of using microfiltration to concentrate and to preserve the bioactivity of minor proteins of milk or whey. In their conclusion, it is stated that more work should be done on the effect of physicochemical parameters such as $\mathrm{pH}$, temperature and ionic strength, 
parameters known to induce denaturation, on the transmission of these bioactive components. 


\subsection{Conclusion and Future Research}

\subsection{Conclusion}

In this body of research, several hypotheses were formulated regarding the quantification of whey protein and its relationship to functionality of the protein in a food system based on a review of current literature. Two series of experiments were conducted based on objectives to test the hypotheses. Conclusions were made based on statistical analysis of the data and are summarized with the hypotheses as follows:

Hypotheses:

1. Whey protein obtained through non-invasive procedures will have the most native structure.

2. Various analytical methods will detect the degree of denaturation of whey proteins differently.

3. The differences detected are relative to functional properties of whey protein.

Conclusions:

- Liquid whey obtained by the centrifugal method of isolation with no heat treatment has significantly less denaturation to the secondary structure than any treatment and can be used as a control for future research

- In terms of sensitivity for quantifying denaturation of whey protein, fluorescence spectroscopy is a superior method, BCA soluble protein at $\mathrm{pH} 4.6>$ native PAGE

- There is a correlation between the responses for denaturation and solubility for the treatments of low heat, freeze dry and high heat, spray dry powders

All three of the methods used for isolating the whey were subjected to relatively mild treatments in terms of defatting, casein removal, and chemical/additive contact; therefore any denaturation was truly imparted by the applied treatment. Whey proteins 
isolated from raw milk via centrifugal force, free of heat treatment, were found to be significantly more native in structure than other whey proteins isolated by enzyme coagulation or membrane filtration and/or subjected to a heat treatment. Such was found to be a useful standard for characterizing native structure in liquid whey.

The methods of measuring denaturation of whey proteins studied were found to varying abilities of quantifying denaturation. While unable to establish significant differences using native PAGE in the current research, qualitatively, native PAGE can be used to evaluate presence of native whey proteins. BCA solubility to measure native protein was found to be acceptable for measuring denaturation through loss of solubility due to denaturation of tertiary structure. This method, however, is rather crude and only sensitive enough to measure substantial differences. Fluorescence Spectroscopy was found to be the most sensitive of the three methods analyzed. Changes in structure are easily detected by the fluorescent emission and were found to be detectable at more sensitive intervals of denaturation than the other two methods studied.

\subsection{Limitations of Research}

As one of the objectives of the research was to define completely native conditions, no preservatives were used throughout experimentation. A twenty four hour window was designated to complete all analysis to avoid spoilage which limited the number of analytical methods that could be evaluated for measuring denaturation to three in the first series of experiments. In the second series of experiments, the quantity of whey needed to spray dry was exponentially greater than that of the freeze dryer could accommodate. Thus the input sample sizes had variance; this was accounted for by thoroughly mixing the whey in effort to get a homogenous sample. 


\subsection{Future Research}

The research completed raises many new questions. Further research should be done emulating the current study and changing the levels of factors, such as implementing a much higher heat treatment or by exploring denaturation using different analytical methods, such as FT-IR, CD, Kjeldahl, and FPLC. Other avenues that would be interesting to explore include conducting similar studies on commercial whey protein powders and/or investing the correlations of denaturation with other functional physical properties or nutritional properties of whey protein.

To further explore the correlation of whey protein denaturation to solubility, an experiment could be designed to explore extreme treatments, $80^{\circ} \mathrm{C}-90^{\circ} \mathrm{C}$ for 30 minutes to completely denature whey proteins for applications where gelation is the principal functional property. Solubility would be expected to be poor and would give further insight as to whether there is a true correlation with methods used for determining denaturation. 


\section{References}

Agrawal, S.G., R.K. Bund, and A.B. Pandit. 2008. Effect of agitation on heat-induced deproteination process of buffalo milk whey. Journal of Food Engineering. 87(3): 398-404.

Aider, M., D. de Halleux, and A. Akbache. 2007. Whey cryoconcentration and impact on its composition. Journal of Food Engineering. 82(1): 92-102.

Akbache, A., E. Lamiot, O. Moroni, S. Turgeon, S.F. Gauthier, and Y. Pouliot. 2009. Use of membrane processing to concentrate TGF-[beta] 2 and IGF-I from bovine milk and whey. Journal of Membrane Science. 326(2): 435-440.

American Dairy Products Institution. 2009. Determination of Solubility Index. p. 30-31. In Bulliten 916: Standards for Grades of Dry Milks Including Methods of Analysis, Elmhurst.

Anand, K., E. Brody, J. Landry, and E. Ward. 1998. Custom Denaturation of Whey Proteins: Thermal Effects. p. 101-115. In International Dairy Publication, Brussels.

Anandharamakrishnan, C., C. Rielly, and A. Stapley. 2008. Loss of solubility of [alpha]lactalbumin and [beta]-lactoglobulin during the spray drying of whey proteins. LWT Food Science and Technology. 41(2): 270-277.

Ardö, Y., O. Lindblad, and K.B. Qvist. 1999. Study of methods to routinely monitor heat load to cheese milk. International Dairy Journal. 9(8): 547-552.

Association of Offical Analytical Chemists. 1980. Official Methods of Analysis. 13th ed. AOAC, Wahington DC.

Aziznia, S., A. Khosrowshahi, A. Madadlou, and J. Rahimi. 2008. Whey Protein Concentrate and Gum Tragacanth as Fat Replacers in Nonfat Yogurt: Chemical, Physical, and Microstructural Properties. Journal of Dairy Science. 91(7): 2545-2552.

Bender, D. 2006. Benders' Dictionary of Nutrition and Food Technology. CRC Press, Boca Raton.

Bischof, J., and X. He. 2006. Thermal Stability of Proteins. Annals of the New York Academy of Sciences. 1066 (Cell Injury: Mechanisms, Responses, and Repair): 1233 .

Brew, K. 2003. Alpha-lactalbumin, in P.F. Fox and P.L.H McSweeny, ed, Advanced Dairy Chemistry. 3rd ed. Kluwer Academic, New York.

Carter, D.C., and J.X. Ho. 1994. Structure of Serum Albumin. p. 153-176, 176a, 176b, 176c, 176d, 176e, 176f, 176g, 176h, 176i, 176j, 176k, 1761, 177-203. In Lipoproteins, 
Apolipoproteins, and Lipases. Academic Press.

Chang, S. 2003. Protein Analysis. p. 131-144. In Food Analysis Suzanne Nielsen. 3rd ed. Kluwer Academic, New York.

Chen, W.L., M.T. Hwang, C.Y. Liau, J.C. Ho, K.C. Hong, and S.J.T. Mao. 2005. \{beta\}Lactoglobulin is a Thermal Marker in Processed Milk as Studied by Electrophoresis and Circular Dichroic Spectra. J. Dairy Sci. 88(5): 1618-1630.

Cheryan, 1998. In Ultrafiltration and microfiltration handbook M. Cheryan. CRC Press, Boca Raton.

Considine, T., H. Patel, S. Anema, H. Singh, and L. Creamer. 2007. Interactions of milk proteins during heat and high hydrostatic pressure treatments -- A Review. Innovative Food Science \& Emerging Technologies. 8(1): 1-23.

Corredig, M., and D.G. Dalgleish. 1996. Effect of temperature and pH on the interactions of whey proteins with casein micelles in skim milk. Food Research International. 29(1): 49-55.

Creamer, L.K., and A.K.H. MacGibbon. 1996. Some recent advances in the basic chemistry of milk proteins and lipids. International Dairy Journal. 6(6): 539-568.

Dairy Council of California. 2004. Whey Protein: Waste Product of the Past is the Nutritional Powerhouse of the Future. Available at http://www.dairycouncilofca.org/pdfs/whey_monograph.pdf.

Daubert, C. A rheological approach to assessing shear effects on biological fluids - NORTH CAROLINA STATE UNIV. USDA Research, Education\&Economics Information system.Available at http://www.reeis.usda.gov/web/crisprojectpages/220255.html accessed 4 May 2010).

Daubert, C., and E.A. Foegeding. 2003. Rheological Principles for Food Analysis. p. 503518. In Food Analysis Suzanne Nielsen. 3rd ed. Kluwer Academic, New York.

Diez, R., M. Ortiz, L. Sarabia, and I. Birlouez-Aragon. 2008. Potential of front face fluorescence associated to PLS regression to predict nutritional parameters in heat treated infant formula models. Analytica Chimica Acta. 606(2): 151-158.

Dissanayake, M., and T. Vasiljevic. 2009. Functional properties of whey proteins affected by heat treatment and hydrodynamic high-pressure shearing. Journal of Dairy Science. 92(4): 1387-1397.

Duxbury, D. 1993. New ingredient provides healthy functional alternative to eggs in bakery goods. Food Processing.: 53:98. 
Elgar, D.F., C.S. Norris, J.S. Ayers, M. Pritchard, D.E. Otter, and K.P. Palmano. 2000. Simultaneous separation and quantitation of the major bovine whey proteins including proteose peptone and caseinomacropeptide by reversed-phase highperformance liquid chromatography on polystyrene-divinylbenzene. Journal of Chromatography A. 878(2): 183-196.

Enomoto, H., C. Li, K. Morizane, H. Ibrahim, Y. Sugimoto, S. Ohki, H. Ohtomo, and T. Aoki. 2008. Improvement of Functional Properties of Bovine Serum Albumin through Phosphorylation by Dry-Heating in the Presence of Pyrophosphate. Journal of Food Science. 73(2): C84-C91.

Fagan, C., M. Leedy, M. Castillo, F. Payne, C. O'Donnell, and D. O'Callaghan. 2007. Development of a light scatter sensor technology for on-line monitoring of milk coagulation and whey separation. Journal of Food Engineering. 83(1): 61-67.

FDA. Pasteurized Milk Ordinance 2007. U.S. Department of Health and Human Services.Available at http://www.fda.gov/Food/FoodSafety/ProductSpecificInformation/MilkSafety/NationalConferenceonInterstateMilkShipmentsNCI MSModelDocuments/PasteurizedMilkOrdinance2007/default.htm (verified 7 May 2010).

Fennema, O. 1996. Food Chemistry. 3rd ed. CRC Press, Boca Raton.

Fernandes de Carvalho, A., and J. Maubois. 2010. Applications of Membrane Technologies in the Dairy Industry. p. 33-56. In Engineering Aspects of Milk and Dairy Products. Contemporary Food Engineering Series. CRC Press, Boca Raton.

Fitzsimons, S.M., D.M. Mulvihill, and E.R. Morris. 2008. Large enhancements in thermogelation of whey protein isolate by incorporation of very low concentrations of guar gum. Food Hydrocolloids. 22(4): 576-586.

Floris, R., I. Bodnár, F. Weinbreck, and A.C. Alting. 2008. Dynamic rearrangement of disulfide bridges influences solubility of whey protein coatings. International Dairy Journal. 18(5): 566-573.

Foegeding, E.A., and P.J. Luck. 2002. MILK PROTEINS I Whey Protein Products. p. 19571960. In Encyclopedia of Dairy Sciences. Elsevier, Oxford.

Foegeding, E.A. 1992. Rheological Properties of Whey Protein Isolate Determined by Torisonal Fracture and Stress Relaxation 1. Journal of Texture Studies. 23(3): 337348.

Foegeding, E.A., E.L. Bowland, and C.C. Hardin. 1995. Factors that determine the fracture properties and microstructure of globular protein gels. Food Hydrocolloids. 9(4): $237-$ 249. 
Fox, P. 2003. Milk Proteins: General and Historical Aspects in P.F. Fox and P.L.H, McSweeny, ed, Advanced Dairy Chemistry. 3rd ed. Kluwer Academic, New York.

Gaiani, D., and R.K. Apenten. 1999. Heat-induced denaturation and aggregation of $\beta$ Lactoglobulin: kinetics of formation of hydrophobic and disulphide-linked aggregates. International Journal of Food Science \& Technology. 34(5-6): 467-476.

Gauthier, S., and Y. Pouliot. 2003. Functional and Biological Properties of Peptides Obtained by Enzymatic Hydrolysis of Whey Proteins. Journal of Dairy Science. 86(Supplement 1): E78-E87.

GEA Niro. 2006. Insolubility Index No. A 3 a., in GEA Niro Analytical Methods, Søborg.

Glanbia Nutritionals, 2010. Whey Peptides and Hydrolysates, Fitchburg.

Grufferty, M.B., and D.M. Mulvihill. 1987. Proteins recovered from milks heated at alkaline pH values. International Journal of Dairy Technology. 40(4): 82-85.

Ha, E. and M.B. Zemel. 2003. Functional properties of whey, whey components, and essential amino acids: mechanisms underlying health benefits for active people (review). The Journal of Nutritional Biochemistry. 14(5): 251-258.

Hambraeus, L. 2003. Nutritional Aspects of Milk Proteins. In: Fox, P.F. and P.L.H. McSweeny, ed, Advanced Dairy Chemistry I: Proteins. 3rd ed. Kluwer Academic, New York.

Harwalkar, V.R. 1979. Comparison of physico-chemical properties of different thermally denatured whey proteins. Milchwissenschaft 34: 419.

Harwalkar, V. 1980. Measurement of Thermal Denaturation of [beta]-Lactoglobulin at $\mathrm{pH}$ 2.5. Journal of Dairy Science. 63(7): 1043-1051.

Havea, P., H. Singh, and L. Creamer. 2001. Characterization of Heat-Induced Aggregates of -Lactalbumin and Bovine Serum Albumin in a Whey Protein Concentrate Environment. Journal of Dairy Research. 68(03): 483-497.

Heino, A., J. Uusi-Ravua, P. Tantamki, and O. Tossavainen. 2007. Functional properties of native and cheese whey protein concentrate powders. International Journal of Dairy Technology. 60(4): 277-285.

Hernandez, A., and F. Harte. 2009. Isolation of caseins from whey proteins by microfiltration modifying the mineral balance in skim milk. Journal of Dairy Science. 92(11): 53575362.

Hinrichs, J. 2001. Incorporation of whey proteins in cheese. International Dairy Journal. 11(4-7): 495-503. 
Hong, Y., and L.K. Creamer. 2002. Changed protein structures of bovine [beta]-lactoglobulin $\mathrm{B}$ and [alpha]-lactalbumin as a consequence of heat treatment. International Dairy Journal. 12(4): 345-359.

Hurley, W. 2003. Immunoglobulins in Mammary Secretions, in P.F., P.L.H McSweeny, ed, Advanced Dairy Chemistry. 3rd ed. Kluwer Academic, New York.

Ju, Z.Y., J. Otte, M. Zakora, and K.B. Qvist. 1997. Enzyme-induced gelation of whey proteins: Effect of protein denaturation. International Dairy Journal. 7(1): 71-78.

Kher, A., P. Udabage, I. McKinnon, D. McNaughton, and M.A. Augustin. 2007. FTIR investigation of spray-dried milk protein concentrate powders. Vibrational Spectroscopy. 44(2): 375-381.

Ko, S., and H. Kwak. 2009. Bioactive Components in Whey Products, in Young Park Bioactive Components in Milk and Dairy Products. Wiley Blackwell, Singnapore.

Korhonen, H., and A. Pihlanto-Leppala. 2002. Formation of Bioactive Peptides From Milk Proteins Through Fermentation by Dairy Starters in Bioactive Compounds in Foods, effects of Processing and Storage edited by Tung-Ching Lee and Chi-Tang Ho. American Chemical Society, Wahington DC.

Kresic, G., V. Lelas, A.R. Jambrak, Z. Herceg, and S.R. Brncic. 2008. Influence of novel food processing technologies on the rheological and thermophysical properties of whey proteins. Journal of Food Engineering. 87(1): 64-73.

Kurzer, M., 2002. Hormonal Effects of Soy in Premenopausal Women and Men. Journal of Nutrition:132 (3): 570

Kuwata, K., S. Era, M. Hoshino, V. Forge, Y. Goto, and C.A. Batt. 1999. Solution structure and dynamics of bovine beta-lactoglobulin A. Protein Science. 8(11): 2541-2545.

Larson, N., B. Ismail, S. Nielsen, and K. Hayes. 2006. Activity of Bacillus polymyxa protease on components of the plasmin system in milk. International Dairy Journal. 16(6): 586-592.

Law, A.J.R., and J. Leaver. 2000. Effect of pH on the Thermal Denaturation of Whey Proteins in Milk. Journal of Agricultural and Food Chemistry. 48(3): 672-679.

Lefevre, T., and M. Subirade. 1999. Structural and interaction properties of \&\#x03B2;Lactoglobulin as studied by FTIR spectroscopy. International Journal of Food Science \& Technology. 34(5-6): 419-428.

Lefevre, T., and M. Subirade. 2001. Molecular structure and interaction of biopolymers as viewed by Fourier transform infrared spectroscopy: model studies on [beta]- 
lactoglobulin. Food Hydrocolloids. 15(4-6): 365-376.

Lehr, C. 2009a. Introduction to Instrumental Analysis. Lecture. Cal Poly, San Luis Obispo.

Lehr, C. 2009b. HPLC. Lecture. Cal Poly, San Luis Obispo.

Liang, M., V.Y. Chen, H. Chen, and W. Chen. 2006. A simple and direct isolation of whey components from raw milk by gel filtration chromatography and structural characterization by Fourier transform Raman spectroscopy. Talanta. 69(5): 12691277.

Lonnerdal, B. 2003. Lactoferrin, in P.F. Fox and P.L.H. McSweeny, ed, Advanced Dairy Chemistry. 3rd ed. Kluwer Academic, New York.

Madureira, A., T. Tavares, A. Gomes, M. Pintado, and F. Malcata. 2010. Invited review: Physiological properties of bioactive peptides obtained from whey proteins. Journal of Dairy Science. 93(2): 437-455.

Manji, B., and Y. Kakuda. 1987. Determination of Whey Protein Denaturation in HeatProcessed Milks: Comparison of Three Methods. Journal of Dairy Science. 70(7): 1355-1361.

Marangoni, A.G., S. Barbut, S.E. McGauley, M. Marcone, and S.S. Narine. 2000. On the structure of particulate gels--the case of salt-induced cold gelation of heat-denatured whey protein isolate. Food Hydrocolloids. 14(1): 61-74.

Marcelo, P.A., and S.S. Rizvi. 2008. Physicochemical properties of liquid virgin whey protein isolate. International Dairy Journal. 18(3): 236-246.

McKenzie, H., and W. Sawyer. 1967. Effect of pH on Beta-Lactoglobulins. Nature. 214: 1101-1104.

McMaster, M. 2007. HPLC, A Practical User's Guide. 2nd ed. Wiley Interscience, Hoboken, NJ.

Mills, O.E., and Creamer, L.K. 1975. A conformational change in bovine beta-lactoglobul... [Biochim Biophys Acta. 1975] - PubMed result. Biochemical Biophys Acta. 379(2): 618-626.

Mine, Y. 1995. Recent advances in the understanding of egg white protein functionality. Trends in Food Science \& Technology. 6(7): 225-232.

Modler, H.W. 2000. Milk Processing. In Nakai \& Modler Food Proteins: Processing Applications. Wiley-VCH, Inc., Canada.

Morr, C., B. German, J. Kinsella, J. Regenstein, J.V. Buren, A. Kilara, B. Lewis, and M. 
Mangino. 1985. A Collaborative Study to Develop a Standardized Food Protein Solubility Procedure. Journal of Food Science. 50(6): 1715-1718.

Mousavi, S.H., A. Bordbar, and T. Haertlé. 2008. Changes in Structure and in Interactions of Heat-Treated Bovine $\beta$-Lactoglobulin. Protein \& Peptide Letters. 15(8): 818-825.

Mulvihill, D., and M. Ennis. 2003. Functional Milk Proteins: Production and Utilization in Fox, P.F. and McSweeny P.L.H, ed, Advanced Dairy Chemistry. 3rd ed. Kluwer Academic, New York.

Murillo Pulgarin, J.A., A.A. Molina, and M.T.A. Pardo. 2005. Fluorescence characteristics of several whey samples subjected to different treatments and conditions. Analytica Chimica Acta. 536(1-2): 153-158.

National Research Council. 1989. Recommended Dietary Allowances. 10th ed. National Academy Press, Wahington DC.

Neocleous, M., D. Barbano, and M. Rudan. 2002. Impact of Low Concentration Factor Microfiltration on the Composition and Aging of Cheddar Cheese. Journal of Dairy Science. 85(10): 2425-2437.

Neville, J.R., K.J. Armstrong, and J. Price. 2001. Ultra Whey 99: a whey protein isolate case study. International Journal of Dairy Technology. 54(4): 127-129.

Onwulata, C.I., P.W. Smith, R.P. Konstance, and V.H. Holsinger. 2001. Incorporation of whey products in extruded corn, potato or rice snacks. Food Research International. 34(8): 679-687.

Onwulata, C., R. Konstance, and P. Tomasula. 2004. Minimizing Variations in Functionality of Whey Protein Concentrates from Different Sources. Journal of Dairy Science. 87(3): 749-756.

Panyam, D., and A. Kilara. 1996. Enhancing the functionality of food proteins by enzymatic modification. Trends in Food Science \& Technology. 7(4): 120-125.

Papadatos, A., M. Neocleous, A. Berger, and D. Barbano. 2003. Economic Feasibility Evaluation of Microfiltration of Milk Prior to Cheesemaking. Journal of Dairy Science. 86(5): 1564-1577.

Park, Y. 2009. Overview of Bioactive Components in Milk and Dairy Products. p. 3-14. In Bioactive Components in Milk and Dairy Products. Wiley Blackwell, Singnapore.

Parris, N., and M.A. Baginski. 1991. A Rapid Method for the Determination of Whey Protein Denaturation. J. Dairy Sci. 74(1): 58-64.

Parris, N., J.M. Purcell, and S.M. Ptashkin. 1991. Thermal denaturation of whey proteins in 
skim milk. Journal of Agricultural and Food Chemistry. 39(12): 2167-2170.

Pelegrine, D.H.G., and C.A. Gasparetto. 2005. Whey proteins solubility as function of temperature and $\mathrm{pH}$. Lebensmittel-Wissenschaft und-Technologie. 38(1): 77-80.

Perez, M.D., and M. Calvo. 1995. Interaction of [beta]-Lactoglobulin with Retinol and Fatty Acids and Its Role as a Possible Biological Function for This Protein: A Review. Journal of Dairy Science. 78(5): 978-988.

Pierce Technology. BCA Protein Assay. Thermo Scientific.Available at http://www.piercenet.com/products/browse.cfm?fldID=02020101 (verified 4 May 2010).

Pike, A., K. Brew, and K. Acharya. 1996. RCSB PDB : Structure Summary for 1HFZ ALPHA-LACTALBUMIN. Protein Databank.Available at http://www.pdb.org/pdb/explore/explore.do?structureId=1HFZ (verified 23 May 2010).

Pomeranz, Y. 1985. Functional Properties of Food Components. Academic Press, INC., Orlando.

Prindiville, E., R. Marshall, and H. Heymann. 2000. Effect of Milk Fat, Cocoa Butter, and Whey Protein Fat Replacers on the Sensory Properties of Lowfat and Nonfat Chocolate Ice Cream. Journal of Dairy Science. 83(10): 2216-2223.

Pruitt, K. 2003. Lactoperoxidase, in Advanced Dairy Chemistry Volume 1A, edited by P.F. Fox and P.L.H McSweeny, ed, 3rd ed. Kluwer Academic, New York.

Pulgarin, J., A. Molina, and M. Pardo. 2005. Fluorescence characteristics of several whey samples subjected to different treatments and conditions. Anal Chim Acta 536(12):153-8.

Qi, X., C. Holt, D. McNulty, S. Brownlow, and G. Jones. 1997. Effect of temperature on the secondary structure of beta-lactoglobulin at $\mathrm{pH} 6.7$, as determined by $\mathrm{CD}$ and $\mathrm{IR}$ spectroscopy: a test of the molten globule hypothesis. Biochemistry Journal. 324: 341-346.

Qin, B., M. Bewley, L. Creamer, E. Baker, and G. Jameson. 1999. Functional Implications of Structural Differences between Variants A and B of Bovine Beta-Lactoglobulin. Protein Science. 8(1): 75-83.

Rasco, B., and Q. Zhong. 2000. Proteins: Basic Concepts. p. 115-130. In Food Chemistry: Priciples and Applications: Christen, Genevieve and Smith, Scott, ed. Science Technology System, ed, West Sacramento.

Rattray, W., and P. Jelen. 1995. Viscous behaviour of whey protein concentrate dispersions. 
International Dairy Journal. 5(7): 673-684.

Relkin, P. 1998. Reversibility of heat-induced conformational changes and surface exposed hydrophobic clusters of [beta]-lactoglobulin: their role in heat-induced sol-gel state transition. International Journal of Biological Macromolecules. 22(1): 59-66.

Ren, J and D.I. Stuart, 1993. $\alpha$-lactalbumin possesses a distinct zinc binding site. The Journal of Biological Chemistry. 268(26): 19292-19298.

Rounds, M.A., and J.F.I. Gregory. 2003. High Perfomance Liquid Chromatography. p. 463478. In Food Analysis Suzanne Nielsen. 3rd ed. Kluwer Academic, New York.

Ruegg, M., and U. Moor. 1977. Calorimetric Study of the Thermal Denaturaion of Whey Proteins in Simulated Milk Ultrafiltrate. Journal of Dairy Research. 44: 509-530.

Saha, B.C. \& K. Hayashi., 2001. Debittering of protein hydrolyzates. Biotechnology Advances. 19(5): 355-370.

Sava, N., I. Van der Plancken, W. Claeys, and M. Hendrickx. 2005. The Kinetics of HeatInduced Structural Changes of [beta]-Lactoglobulin. Journal of Dairy Science. 88(5): 1646-1653.

Sawyer, L. 2003. Beta-lactoglobulin, in P.F Fox and P.L.H. McSweeny, ed, Advanced Dariy Chemistry. 3rd ed. Kluwer Academic, New York.

Schmidt, R.H., V.S. Packard, and H.A. Morris. 1984. Effect of Processing on Whey Protein Functionality. J. Dairy Sci. 67(11): 2723-2733.

Sheehan, D. 1996. Protein Purification Protocols. Humana Press, New York.

Shi, L., Q. Zhang, W. Rui, M. Lu, X. Jing, T. Shang, and J. Tang. 2004. BioPD: a web-based information center for bioactive peptides. Regulatory Peptides. 120(1-3): 1-3.

Sikorski, Z. 2001. Functional Properties of Proteins in Food Systems, in Z. Sikorski Chemical and Functional Properties of Food Proteins. Technomic Publishing Co., Lancaster, Pn.

Sindayikengera, S. \& W. Shui. 2006. Nutritional Evaluation of Caseins and Whey Protein and their Hydrolysates from Protamex. J. Amer. Diet Assoc. 2: 90-98.

Singh, H., and P. Havea. 2003. Thermal Denaturation, Aggregation and Gelation of Whey Proteins, In P.L Fox and P.L.H McSweeny, ed, Advanced Dairy Chemistry. 3rd ed. Kluwer Academic, New York.

Skoog,, D., Donald West, Holler, James, and Crouch, Stanley. 2009. Instrumental Analysis. Cengage, Mason. 
Smith, D. 2003. Protein Separation and Characterization Procedures. p. 247-268. In Food Analysis Suzanne Nielsen. 3rd ed. Kluwer Academic, New York.

Smith, D., and J.D. Culbertson. 2000. Proteins: Functional Properties. p. 131-148. In Food Chemistry: Principles and Applications: Christen, Genevieve and Smith, Scott. Science Technology System, ed, West Sacramento.

Strasburg, G.M., and R.D. Ludescher. 1995. Theory and applications of fluorescence spectroscopy in food research. Trends in Food Science \& Technology. 6(3): 69-75.

Tremblay, L., M. Laporte, D. Leonil, D. Dupont, and P. Paquin. 2003. Quantitation of Proteins in Milk and Milk Products, in P.F. Fox and P.L.H McSweeny, ed, Advanced Dairy Chemistry. 3rd ed. Kluwer Academic, New York.

USDA Agriculture Marketing Sevice. 2001. United States Standards for Grades of Nonfat Dry Milk. Dairy Programs, Washington, D.C.

Vardhanabhuti, B., and E.A. Foegeding. 1999. Rheological Properties and Characterization of Polymerized Whey Protein Isolates. Journal of Agricultural and Food Chemistry. 47(9): 3649-3655.

Vijayalakshmi, L., R. Krishna, R. sankaranarayanan, and M. Vijayan. RCSB PDB : Structure Summary for 2Q2M - Beta-lactoglobulin (native). Protein Databank.Available at http://www.pdb.org/pdb/explore/explore.do?structureId=2Q2M (verified 23 May 2010).

Walsh, M., and S. Duncan. 2000. Milk. p. 291-310. In Food Chemistry: Priciples and Applications: Christen, Genevieve and Smith, Scott, ed. Science Technology System, West Sacramento.

Whey Protein Institute. 2010. Methods of Assessing Protein Quality. Available at http://www.wheyoflife.org/ (verified 23 May 2010).

Whitney, E. 2002. Understanding Nutrition. 11th ed. Wadsworth, Belmont.

Whrolstand, R. 2001. Current Protocols in Food Analytical Chemistry. Wiley, New York.

Wiechelman, K.J., Braun, R.D. \& Fitzpatrick, J.D., 1988. Investigation of the bicinchoninic acid protein assay: Identification of the groups responsible for color formation. Analytical Biochemistry, 175(1), 231-237.

Wildman, R., and D. Medeiros. 2000. Advanced Human Nutrition. CRC Press, Boca Raton.

Ye, A., 2008. Complexation between milk proteins and polysaccharides via electrostatic interaction: principles and applications-a review. International Journal of Food 
Science \& Technology, 43(3), 406-415.

Yetim, H., W.D. Moller, and M. Eber. 2001. Using fluid whey in comminuted meat products: effects on technological, chemical and sensory properties of frankfurter-type sausages. Food Research International. 34(2-3): 97-101.

Yun, J.J., D.M. Barbano, P.S. Kindstedt, and K.L. Larose. 1995. Mozzarella Cheese: Impact of Whey pH at Draining on Chemical Composition, Proteolysis, and Functional Properties. Journal of Dairy Science. 78(1): 1-7.

Zayas, J. 1997. Functionality of Proteins in Foods. Springer, New York. 


\section{Appendices}

\section{Appendix 1: Statistical Analysis for Experiment 1 (SAS)}

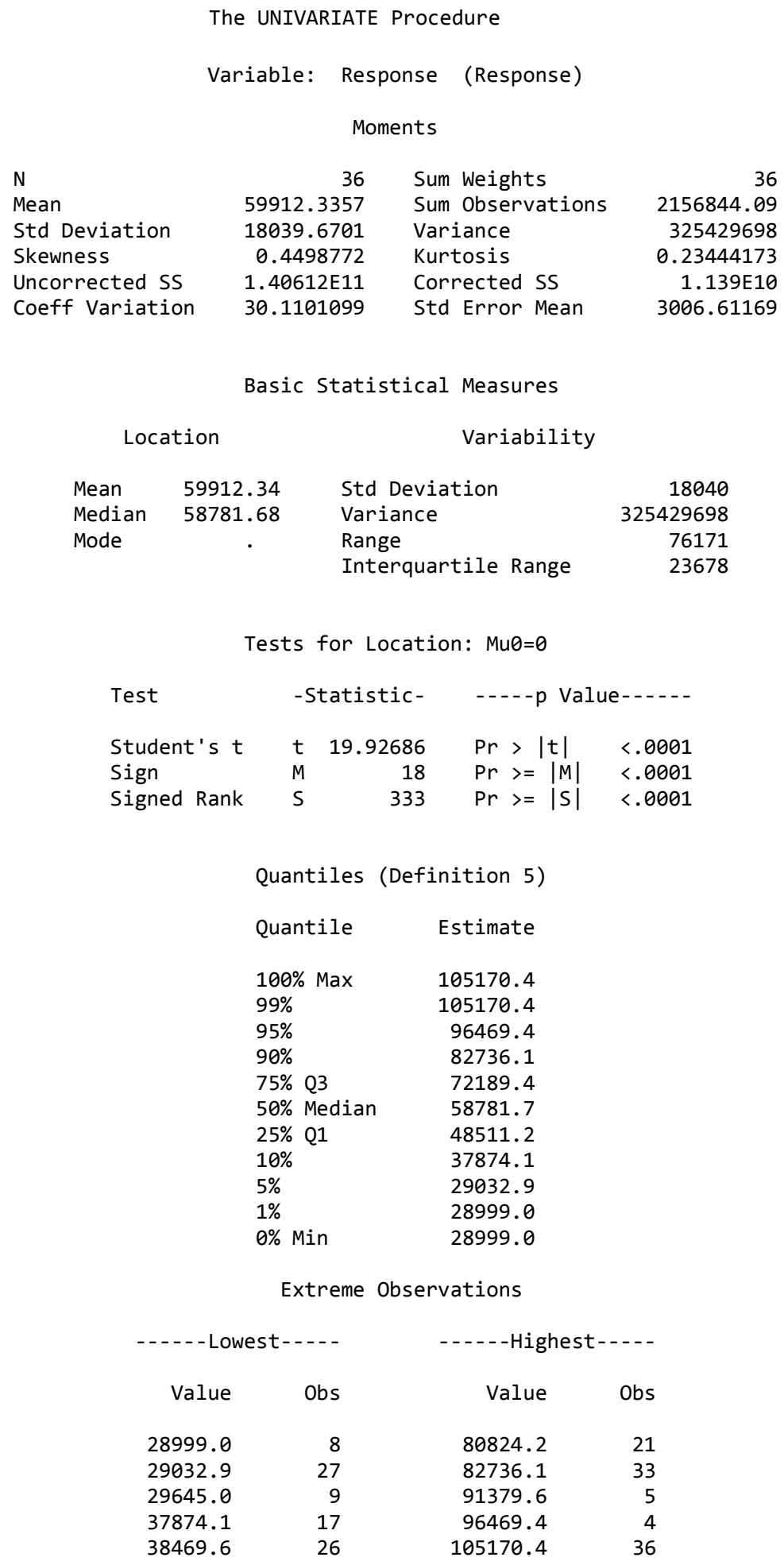


The UNIVARIATE Procedure Variable: Response (Response)

$\begin{array}{rl}\text { Stem } & \text { Leaf } \\ 10 & 5 \\ +\quad 10 & \\ ++\quad 9 & 6 \\ +++\quad 9 & 1 \\ +++\quad & \\ & 8 \\ 8 & 13 \\ 7 & 8 \\ 7 & 2334 \\ 6 & 7 \\ 6 & 0012224 \\ 5 & 5688 \\ 5 & 044 \\ 4 & 68899 \\ 4 & 3 \\ 3 & 88 \\ 3 & 0 \\ 2 & 99 \\ & ---+---+---+---+ \\ -+--+ & \\ \text { Multiply Stem. Leaf by } 10 * *+4\end{array}$

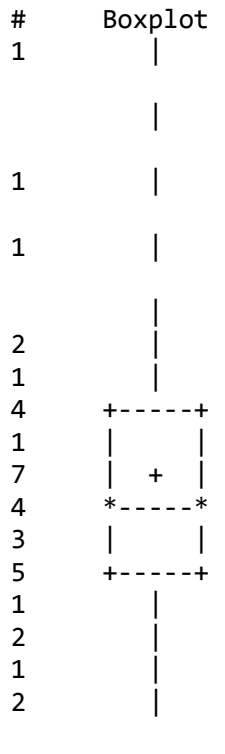

$* *+4$

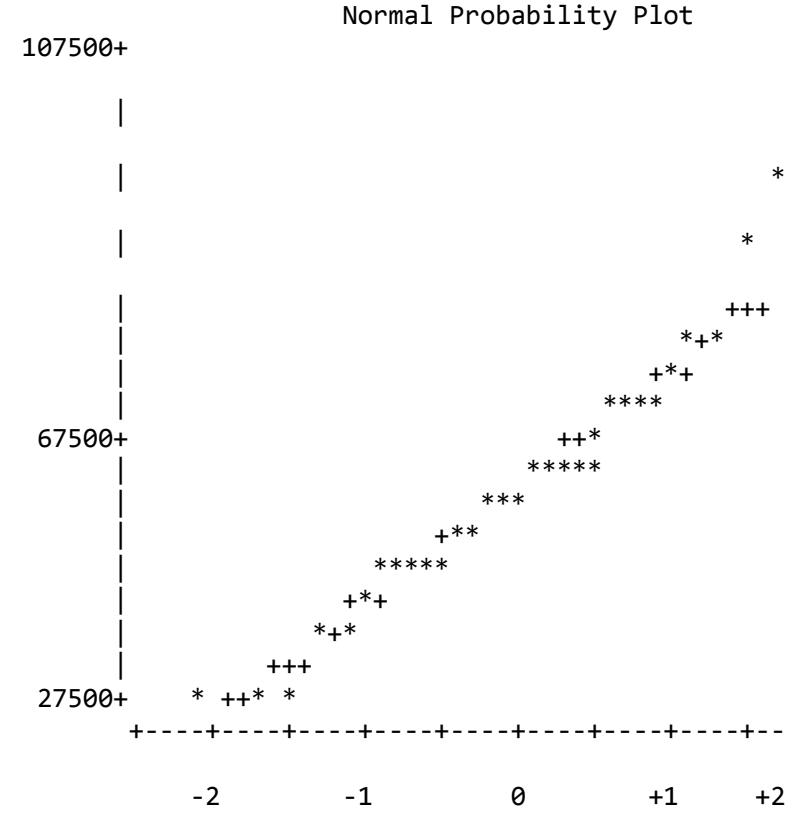

The Mixed Procedure

Model Information
Data Set

Dependent Variable

Covariance Structure

Estimation Method

Residual Variance Method

Fixed Effects SE Method

Degrees of Freedom Method
WORK.SET1

Response

Variance Components

REML

Profile

Model-Based

Containment

Class Level Information

Class
Day
Isolation
Heat

Levels Values

$\begin{array}{ll}4 & 1234 \\ 3 & \text { Centrifuge Enzyme Filtration } \\ 3 & \text { high heat mild heat no heat }\end{array}$

Dimensions

$\begin{array}{lr}\text { Covariance Parameters } & 3 \\ \text { Columns in X } & 16 \\ \text { Columns in Z } & 16 \\ \text { Subjects } & 1 \\ \text { Max Obs Per Subject } & 36\end{array}$

Number of Observations

Number of Observations Read

Number of Observations Used 
Iteration History

$\begin{array}{rrrrr}\text { Iteration } & \text { Evaluations } & -2 \text { Res Log Like } & \text { Criterion } \\ 0 & 1 & 615.89416589 & \\ 1 & 2 & 615.55104941 & 0.00000000\end{array}$

Convergence criteria met.

Covariance Parameter Estimates

$\begin{array}{lr}\text { Cov Parm } & \text { Estimate } \\ \text { Day } & 0 \\ \text { Day*Isolation } & 34553560 \\ \text { Residual } & 2.6294 \mathrm{E} 8\end{array}$

Fit Statistics

$\begin{array}{ll}-2 \text { Res Log Likelihood } & 615.6 \\ \text { AIC (smaller is better) } & 619.6 \\ \text { AICC (smaller is better) } & 620.1 \\ \text { BIC (smaller is better) } & 618.3\end{array}$

Type 3 Tests of Fixed Effects

\begin{tabular}{|c|c|c|c|c|}
\hline & Num & Den & & \\
\hline Effect & DF & DF & F Value & $\mathrm{Pr}>\mathrm{F}$ \\
\hline Isolation & 2 & 6 & 3.80 & 0.0860 \\
\hline Heat & 2 & 18 & 0.15 & 0.8628 \\
\hline Isolation*Heat & 4 & 18 & 0.47 & 0.7563 \\
\hline
\end{tabular}

The Mixed Procedure

Least Squares Means

$\begin{array}{lllrrrrr}\text { Effect } & \text { Isolation } & \text { Heat } & \text { Estimate } & \begin{array}{r}\text { Standard } \\ \text { Error }\end{array} & \text { DF } & \text { t Value } & \text { Pr }>|t| \\ \text { Isolation } & \text { Centrifuge } & & 63667 & 5527.20 & 6 & 11.52 & <.0001 \\ \text { Isolation } & \text { Enzyme } & & 68302 & 5527.20 & 6 & 12.36 & <.0001 \\ \text { Isolation } & \text { Filtration } & & 47767 & 5527.20 & 6 & 8.64 & 0.0001 \\ \text { Heat } & & \text { high heat } & 61283 & 4979.05 & 18 & 12.31 & <.0001 \\ \text { Heat } & & \text { mild heat } & 57866 & 4979.05 & 18 & 11.62 & <.0001 \\ \text { Heat } & & \text { no heat } & 60587 & 4979.05 & 18 & 12.17 & <.0001 \\ \text { Isolation*Heat } & \text { Centrifuge } & \text { high heat } & 65223 & 8623.97 & 18 & 7.56 & <.0001 \\ \text { Isolation*Heat } & \text { Centrifuge } & \text { mild heat } & 64915 & 8623.97 & 18 & 7.53 & <.0001 \\ \text { Isolation*Heat } & \text { Centrifuge } & \text { no heat } & 60864 & 8623.97 & 18 & 7.06 & <.0001 \\ \text { Isolation*Heat } & \text { Enzyme } & \text { high heat } & 66858 & 8623.97 & 18 & 7.75 & <.0001 \\ \text { Isolation*Heat } & \text { Enzyme } & \text { mild heat } & 70068 & 8623.97 & 18 & 8.12 & <.0001 \\ \text { Isolation*Heat } & \text { Enzyme } & \text { no heat } & 67981 & 8623.97 & 18 & 7.88 & <.0001 \\ \text { Isolation*Heat } & \text { Filtration } & \text { high heat } & 51769 & 8623.97 & 18 & 6.00 & <.0001 \\ \text { Isolation*Heat } & \text { Filtration } & \text { mild heat } & 38616 & 8623.97 & 18 & 4.48 & 0.0003 \\ \text { Isolation*Heat } & \text { Filtration } & \text { no heat } & 52917 & 8623.97 & 18 & 6.14 & <.0001\end{array}$


Differences of Least Squares Means

\begin{tabular}{|c|c|c|c|c|c|c|c|c|c|}
\hline Effect & Isolation & Heat & Isolation & Heat & Estimate & $\begin{array}{r}\text { Standard } \\
\text { Error }\end{array}$ & DF & $t$ Value & $\operatorname{Pr}>|t|$ \\
\hline Isolation & Centrifuge & & Enzyme & & -4635.07 & 7816.63 & 6 & -0.59 & 0.5749 \\
\hline Isolation & Centrifuge & & Filtration & & 15900 & 7816.63 & 6 & 2.03 & 0.0882 \\
\hline Isolation & Enzyme & & Filtration & & 20535 & 7816.63 & 6 & 2.63 & 0.0392 \\
\hline Heat & & high heat & & mild heat & 3416.53 & 6619.89 & 18 & 0.52 & 0.6121 \\
\hline Heat & & high heat & & no heat & 695.52 & 6619.89 & 18 & 0.11 & 0.9175 \\
\hline Heat & & mild heat & & no heat & -2721.00 & 6619.89 & 18 & -0.41 & 0.6859 \\
\hline Isolation*Heat & Centrifuge & high heat & Centrifuge & mild heat & 307.34 & 11466 & 18 & 0.03 & 0.9789 \\
\hline Isolation*Heat & Centrifuge & high heat & Centrifuge & no heat & 4358.70 & 11466 & 18 & 0.38 & 0.7083 \\
\hline Isolation*Heat & Centrifuge & high heat & Enzyme & high heat & -1635.12 & 12196 & 18 & -0.13 & 0.8948 \\
\hline Isolation*Heat & Centrifuge & high heat & Enzyme & mild heat & -4845.56 & 12196 & 18 & -0.40 & 0.6958 \\
\hline Isolation*Heat & Centrifuge & high heat & Enzyme & no heat & -2758.50 & 12196 & 18 & -0.23 & 0.8236 \\
\hline Isolation*Heat & Centrifuge & high heat & Filtration & high heat & 13454 & 12196 & 18 & 1.10 & 0.2845 \\
\hline Isolation*Heat & Centrifuge & high heat & Filtration & mild heat & 26607 & 12196 & 18 & 2.18 & 0.0426 \\
\hline Isolation*Heat & Centrifuge & high heat & Filtration & no heat & 12305 & 12196 & 18 & 1.01 & 0.3264 \\
\hline Isolation*Heat & Centrifuge & mild heat & Centrifuge & no heat & 4051.35 & 11466 & 18 & 0.35 & 0.7279 \\
\hline Isolation*Heat & Centrifuge & mild heat & Enzyme & high heat & -1942.46 & 12196 & 18 & -0.16 & 0.8752 \\
\hline Isolation*Heat & Centrifuge & mild heat & Enzyme & mild heat & -5152.90 & 12196 & 18 & -0.42 & 0.6777 \\
\hline Isolation*Heat & Centrifuge & mild heat & Enzyme & no heat & -3065.84 & 12196 & 18 & -0.25 & 0.8044 \\
\hline Isolation*Heat & Centrifuge & mild heat & Filtration & high heat & 13147 & 12196 & 18 & 1.08 & 0.2953 \\
\hline Isolation*Heat & Centrifuge & mild heat & Filtration & mild heat & 26299 & 12196 & 18 & 2.16 & 0.0448 \\
\hline Isolation*Heat & Centrifuge & mild heat & Filtration & no heat & 11998 & 12196 & 18 & 0.98 & 0.3383 \\
\hline Isolation*Heat & Centrifuge & no heat & Enzyme & high heat & -5993.81 & 12196 & 18 & -0.49 & 0.6290 \\
\hline Isolation*Heat & Centrifuge & no heat & Enzyme & mild heat & -9204.26 & 12196 & 18 & -0.75 & 0.4602 \\
\hline Isolation*Heat & Centrifuge & no heat & Enzyme & no heat & -7117.19 & 12196 & 18 & -0.58 & 0.5668 \\
\hline Isolation*Heat & Centrifuge & no heat & Filtration & high heat & 9095.16 & 12196 & 18 & 0.75 & 0.4655 \\
\hline Isolation*Heat & Centrifuge & no heat & Filtration & mild heat & 22248 & 12196 & 18 & 1.82 & 0.0848 \\
\hline Isolation*Heat & Centrifuge & no heat & Filtration & no heat & 7946.41 & 12196 & 18 & 0.65 & 0.5229 \\
\hline Isolation*Heat & Enzyme & high heat & Enzyme & mild heat & -3210.44 & 11466 & 18 & -0.28 & 0.7827 \\
\hline Isolation*Heat & Enzyme & high heat & Enzyme & no heat & -1123.38 & 11466 & 18 & -0.10 & 0.9230 \\
\hline Isolation*Heat & Enzyme & high heat & Filtration & high heat & 15089 & 12196 & 18 & 1.24 & 0.2319 \\
\hline Isolation*Heat & Enzyme & high heat & Filtration & mild heat & 28242 & 12196 & 18 & 2.32 & 0.0326 \\
\hline Isolation*Heat & Enzyme & high heat & Filtration & no heat & 13940 & 12196 & 18 & 1.14 & 0.2680 \\
\hline Isolation*Heat & Enzyme & mild heat & Enzyme & no heat & 2087.06 & 11466 & 18 & 0.18 & 0.8576 \\
\hline Isolation*Heat & Enzyme & mild heat & Filtration & high heat & 18299 & 12196 & 18 & 1.50 & 0.1508 \\
\hline Isolation*Heat & Enzyme & mild heat & Filtration & mild heat & 31452 & 12196 & 18 & 2.58 & 0.0189 \\
\hline Isolation*Heat & Enzyme & mild heat & Filtration & no heat & 17151 & 12196 & 18 & 1.41 & 0.1767 \\
\hline Isolation*Heat & Enzyme & no heat & Filtration & high heat & 16212 & 12196 & 18 & 1.33 & 0.2004 \\
\hline Isolation*Heat & Enzyme & no heat & Filtration & mild heat & 29365 & 12196 & 18 & 2.41 & 0.0270 \\
\hline Isolation*Heat & Enzyme & no heat & Filtration & no heat & 15064 & 12196 & 18 & 1.24 & 0.2327 \\
\hline Isolation*Heat & Filtration & high heat & Filtration & mild heat & 13153 & 11466 & 18 & 1.15 & 0.2664 \\
\hline Isolation*Heat & Filtration & high heat & Filtration & no heat & -1148.74 & 11466 & 18 & -0.10 & 0.9213 \\
\hline Isolation*Heat & Filtration & mild heat & Filtration & no heat & -14301 & 11466 & 18 & -1.25 & 0.2283 \\
\hline
\end{tabular}

The UNIVARIATE Procedure

Variable: Response (Response)

Moments

N

Mean

Std Deviation

Skewness

Uncorrected SS

Coeff Variation
36

19.8483721

8.02845787

0.12518356

16438.4482

40.4489489
Sum Weights

Sum Observations

Variance

Kurtosis

Corrected SS

Std Error Mean
.5749

0.0392

0.6121

.6859

0.9789

.8948

0.6958

.2845

0.0426

0.3264

0.8752

0.8044

0.2953

0.3383

.6290

0.4602

0.4655

0.0848

.7827

0.92319

.0326

.2680

0.1508

0.0189
0.1767

.2004

0.0270

.2664

0.9213

Basic Statistical Measures

Location

$\begin{array}{ll}\text { Mean } & 19.84837 \\ \text { Median } & 18.75376 \\ \text { Mode } & 10.41122\end{array}$

Variability

$\begin{array}{lr}\text { Std Deviation } & 8.02846 \\ \text { Variance } & 64.45614 \\ \text { Range } & 32.74272 \\ \text { Interquartile Range } & 10.73601\end{array}$

NOTE: The mode displayed is the smallest of 9 modes with a count of 2 .

Tests for Location: Mu $\theta=0$

$\begin{array}{lrrrr}\text { Test } & \text {-Statistic- } & ----p \text { Value-.-.-. } \\ \text { Student's } t & t & 14.83351 & \operatorname{Pr}>|t| & <.0001 \\ \text { Sign } & M & 18 & \operatorname{Pr}>=|M| & <.0001\end{array}$




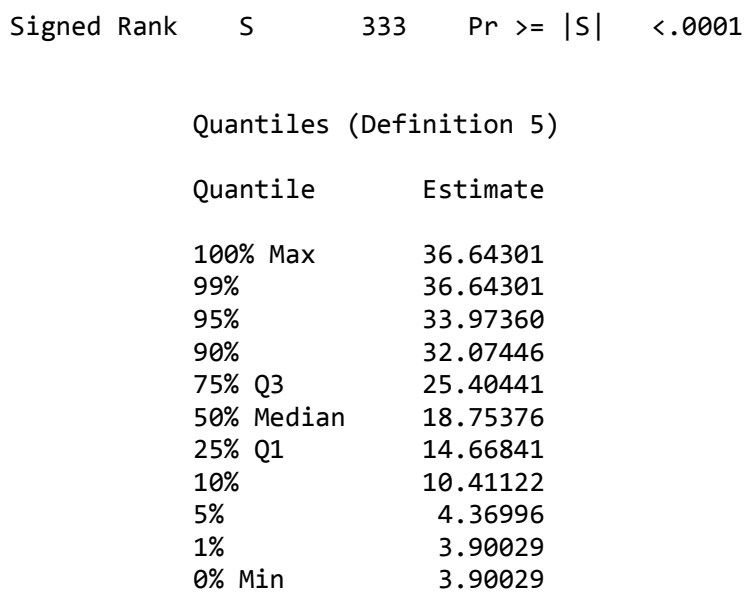

Extreme Observations

$\begin{array}{cccr} & & & \\ \text { Value } & \text { Obs } & \text { Value } & \text { Obs } \\ 3.90029 & 19 & 29.0716 & 24 \\ 4.36996 & 28 & 32.0745 & 30 \\ 7.07932 & 20 & 33.9736 & 6 \\ 10.41122 & 10 & 33.9736 & 15 \\ 10.41122 & 1 & 36.6430 & 33\end{array}$

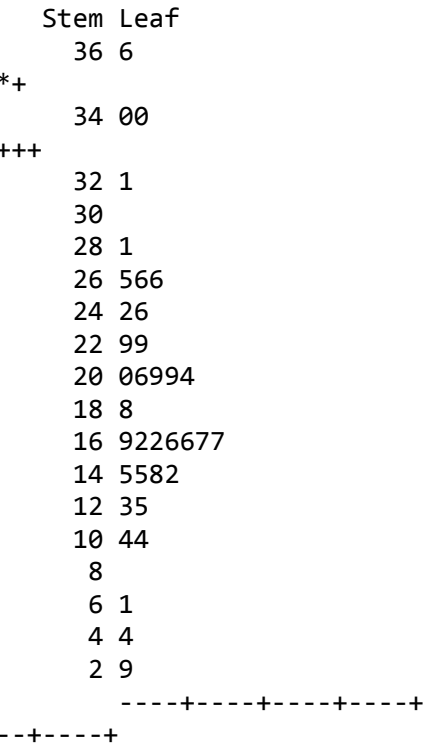

\begin{tabular}{|c|c|}
\hline \# & Boxplot \\
\hline 2 & \\
\hline 1 & \\
\hline 1 & \\
\hline 3 & \\
\hline 2 & +-----+ \\
\hline 2 & $\mid$ \\
\hline 5 & i \\
\hline 1 & $*--+--*$ \\
\hline 7 & 1 \\
\hline 4 & +----++ \\
\hline 2 & \\
\hline 2 & \\
\hline 1 & \\
\hline 1 & \\
\hline 1 & i \\
\hline
\end{tabular}

The UNIVARIATE Procedure Variable: Response (Response) 
The Mixed Procedure

Model Information

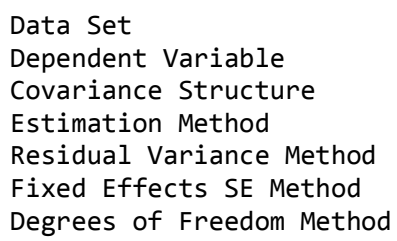

Class Level Information

Class

Day

Isolation

Heat
Levels Values

$\begin{array}{lllll}4 & 1 & 2 & 3 & 4\end{array}$

3 Centrifuge Enzyme Filtration

3 high heat mild heat no heat

\section{Dimensions}

$\begin{array}{lr}\text { Covariance Parameters } & 3 \\ \text { Columns in X } & 16 \\ \text { Columns in Z } & 16 \\ \text { Subjects } & 1 \\ \text { Max Obs Per Subject } & 36\end{array}$

Number of Observations

Number of Observations Read

Number of Observations Used

Number of Observations Not Used

Iteration History

Iteration

Evaluations

-2 Res Log Like

Criterion

0

$1 \quad 153.39352172$

$1 \quad 143.59382925$

0.00000000

Convergence criteria met.

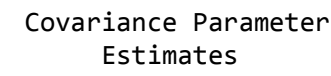

2.9962

Day*Isolation

3.2496

Residual

4.5728

Fit Statistics

-2 Res Log Likelihood

143.6

AIC (smaller is better)

149.6

AICC (smaller is better)

150.6

BIC (smaller is better)

147.8 
Type 3 Tests of Fixed Effects

$\begin{array}{lrrrl}\text { Effect } & \begin{array}{r}\text { Num } \\ \text { DF }\end{array} & \begin{array}{r}\text { Den } \\ \text { DF }\end{array} & \text { F Value } & \text { Pr }>\text { F } \\ \text { Isolation } & 2 & 6 & 9.46 & 0.0140 \\ \text { Heat } & 2 & 18 & 163.94 & <.0001 \\ \text { Isolation*Heat } & 4 & 18 & 10.59 & 0.0001\end{array}$

The Mixed Procedure

Least Squares Means

$\begin{array}{lllrrrrr}\text { Effect } & \text { Isolation } & \text { Heat } & \text { Estimate } & \begin{array}{r}\text { Standard } \\ \text { Error }\end{array} & \text { DF } & \text { t Value } & \text { Pr }>\text { t } \mid \\ & & & & & & & \\ \text { Isolation } & \text { Centrifuge } & & 16.0582 & 1.3937 & 6 & 11.52 & <.0001 \\ \text { Isolation } & \text { Enzyme } & & 22.4578 & 1.3937 & 6 & 16.11 & <.0001 \\ \text { Isolation } & \text { Filtration } & & 21.0291 & 1.3937 & 6 & 15.09 & <.0001 \\ \text { Heat } & & \text { high heat } & 28.4514 & 1.1836 & 18 & 24.04 & <.0001 \\ \text { Heat } & & \text { mild heat } & 18.1860 & 1.1836 & 18 & 15.36 & <.0001 \\ \text { Heat } & & \text { no heat } & 12.9078 & 1.1836 & 18 & 10.91 & <.0001 \\ \text { Isolation*Heat } & \text { Centrifuge } & \text { high heat } & 26.7373 & 1.6446 & 18 & 16.26 & <.0001 \\ \text { Isolation*Heat } & \text { Centrifuge } & \text { mild heat } & 14.1640 & 1.6446 & 18 & 8.61 & <.0001 \\ \text { Isolation*Heat } & \text { Centrifuge } & \text { no heat } & 7.2732 & 1.6446 & 18 & 4.42 & 0.0003 \\ \text { Isolation*Heat } & \text { Enzyme } & \text { high heat } & 33.4155 & 1.6446 & 18 & 20.32 & <.0001 \\ \text { Isolation*Heat } & \text { Enzyme } & \text { mild heat } & 18.4670 & 1.6446 & 18 & 11.23 & <.0001 \\ \text { Isolation*Heat } & \text { Enzyme } & \text { no heat } & 15.4910 & 1.6446 & 18 & 9.42 & <.0001 \\ \text { Isolation*Heat } & \text { Filtration } & \text { high heat } & 25.2014 & 1.6446 & 18 & 15.32 & <.0001 \\ \text { Isolation*Heat } & \text { Filtration } & \text { mild heat } & 21.9268 & 1.6446 & 18 & 13.33 & <.0001 \\ \text { Isolation*Heat } & \text { Filtration } & \text { no heat } & 15.9592 & 1.6446 & 18 & 9.70 & <.0001\end{array}$

Differences of Least Squares Means

\begin{tabular}{|c|c|c|c|c|c|c|c|c|c|}
\hline Effect & Isolation & Heat & Isolatio & Heat & Estimate & $\begin{array}{r}\text { Standard } \\
\text { Error }\end{array}$ & $\mathrm{DF}$ & t Value & $\operatorname{Pr}>|t|$ \\
\hline Isolation & Centrifuge & & Enzyme & & -6.3996 & 1.5450 & 6 & -4.14 & 0.00 \\
\hline Isolation & Centrifuge & & Filtration & & -4.9710 & 1.5450 & 6 & -3.22 & 0.0182 \\
\hline Isolation & Enzyme & & Filtration & & 1.4287 & 1.5450 & 6 & 0.92 & 0.3908 \\
\hline Heat & & high heat & & mild heat & 10.2654 & 0.8730 & 18 & 11.76 & $<.0001$ \\
\hline Heat & & high heat & & no heat & 15.5436 & 0.8730 & 18 & 17.80 & $<.0001$ \\
\hline Heat & & mild heat & & no heat & 5.2782 & 0.8730 & 18 & 6.05 & $<.0001$ \\
\hline Isolation*Heat & Centrifuge & high heat & entrifuge & mild heat & 12.5732 & 1.5121 & 18 & 8.32 & $<.0001$ \\
\hline Isolation*Heat & Centrifuge & high heat & Centrifuge & no heat & 19.4641 & 1.5121 & 18 & 12.87 & $<.0001$ \\
\hline Isolation*Heat & Centrifuge & high heat & Enzyme & high heat & -6.6782 & 1.9777 & 18 & -3.38 & 0.0034 \\
\hline Isolation*Heat & Centrifuge & high heat & Enzyme & mild heat & 8.2703 & 1.9777 & 18 & 4.18 & 0.0006 \\
\hline Isolation*Heat & Centrifuge & high heat & Enzyme & no heat & 11.2463 & 1.9777 & & 5.69 & $<.0001$ \\
\hline Isolation*Heat & Centr & high heat & tion & high heat & 1.5358 & & 1 & 0.78 & 4475 \\
\hline Isolation*Heat & Centrifuge & high heat & Filtration & mild heat & 4.8104 & 1.9777 & 18 & 2.43 & 0.0257 \\
\hline Isolat & Cent & high heat & tion & no heat & 10.7781 & 1.9777 & & 5.45 & .0001 \\
\hline Isola & Cent & mild heat & ifuge & no heat & 6.8909 & 1.5121 & & 4.56 & .0002 \\
\hline Isolation*Heat & Centrifuge & mild heat & Enzyme & high heat & -19.2514 & 1.9777 & 18 & -9.73 & .0001 \\
\hline Isolatio & Centr & mild heat & $\mathrm{nz}$ & mild heat & -4.3029 & 1.5 & & -2.18 & 0.0431 \\
\hline Isola & Cent & ild heat & (Enדו & 0 heat & -1.3269 & 1.9777 & & -0.67 & 0.5108 \\
\hline Isol & Cent & mild heat & tion & high heat & -11 & 1.9777 & 18 & -5.58 & 0001 \\
\hline Isolation*Heat & Centrifuge & mild heat & Filtration & mild heat & -7.7628 & 1.9777 & 18 & -3.93 & 0.0010 \\
\hline Iso & Cen & mild heat & tion & eat & -1 & 77 & & -0.91 & 0.3760 \\
\hline Isola & Cent & no heat & nz) & high heat & -26.1423 & 1.9777 & 18 & -13.22 & $<.0001$ \\
\hline Isolation*Heat & Centrifuge & no heat & Enzyme & mild heat & -11.1938 & 1.9777 & 18 & -5.66 & $<.0001$ \\
\hline Iso. & Cen & no heat & E & & & 1. & & -4.16 & 0.0006 \\
\hline Isol & Cen & no heat & ion & igh heat & -17.9282 & 1.9777 & 10 & -9.07 & $<.0001$ \\
\hline Isolatio & Cent & no heat & Filt & ild heat & -14.6537 & 1.9777 & 18 & -7.41 & $<.0001$ \\
\hline Isolatio & Cent & no heat & tion & no heat & -8.6860 & 1. & $18>$ & -4.39 & 0.0004 \\
\hline Isol & Enzy & high heat & Enz & mild heat & 85 & & & 9.89 & $<.0001$ \\
\hline Isol & Enz & high heat & $\mathrm{E}$ & heat & 17.9245 & 1.5 & 18 & 11.85 & $<.0001$ \\
\hline Iso] & Enz & high heat & Fil & high heat & 8.2140 & 1.9777 & 18 & 4.15 & 0.0006 \\
\hline Iso & & high heat & & mild heat & 86 & 77 & & 5.81 & (19091 \\
\hline Heat & Enz & high heat & tion & no heat & 17.4563 & 1.9777 & 18 & 8.83 & .0001 \\
\hline Isolatior & Enzyme & mild heat & Enzy & no heat & 2.9760 & 1.5121 & 18 & 1.97 & 0.0646 \\
\hline Iso & Enzy & mild heat & & hiah hos & & & & -3.41 & 0.0032 \\
\hline Iso & Enz & mild heat & on & heat & -3.4 & 77 & 1 & -1.75 & 0.0972 \\
\hline Isolatio & Enzy & mild heat & ion & no & 2.5078 & 1.9777 & 18 & 1.27 & 0.2209 \\
\hline Isolation*Heat & Enzyme & no heat & tion & high heat & -9.7104 & 1.9777 & 18 & -4.91 & 0.0001 \\
\hline & & no heat & & & & & 1 & -3.25 & .0044 \\
\hline Iso] & Enzy & no heat & & no & -0.4682 & 1.9 & 18 & -0.24 & 0.8155 \\
\hline Heat & Filtrat & high heat & tion & mild heat & 3.2746 & 1.5121 & 18 & 2.17 & \\
\hline Heat & Fil & high heat & $\mathrm{Fi}$ & no & 9.2422 & & 18 & 6.11 & \\
\hline Isolation*Heat & Filtration & mild heat & Filtration & no heat & 5.9676 & 1.5121 & 18 & 3.95 & 0.00 \\
\hline
\end{tabular}


The UNIVARIATE Procedure Variable: Response (Response)

\begin{tabular}{lrlr} 
& \multicolumn{2}{c}{ Moments } \\
N & 36 & Sum Weights & 36 \\
Mean & 88.2236224 & Sum Observations & 3176.05041 \\
Std Deviation & 10.0750215 & Variance & 101.506058 \\
Skewness & -0.4935215 & Kurtosis & -0.0867217 \\
Uncorrected SS & 283755.384 & Corrected SS & 3552.71204 \\
Coeff Variation & 11.4198683 & Std Error Mean & 1.67917025
\end{tabular}

Basic Statistical Measures

\begin{tabular}{lclr}
\multicolumn{2}{c}{ Location } & \multicolumn{2}{c}{ Variability } \\
Mean & 88.22362 & Std Deviation & 10.07502 \\
Median & 89.53815 & Variance & 101.50606 \\
Mode & $\cdot$ & Range & 41.84414 \\
& & Interquartile Range & 12.23525
\end{tabular}

Tests for Location: Mu$\theta=0$

\begin{tabular}{|c|c|c|c|c|}
\hline Test & & Statist & tic- & --- \\
\hline Student's $t$ & $\mathrm{t}$ & 52.54 & 4001 & $\mathrm{Pr}>$ \\
\hline Sign & M & & 18 & $\operatorname{Pr}>=$ \\
\hline Signed Rank & $\mathrm{s}$ & & 333 & $\operatorname{Pr}>=$ \\
\hline & Quan & tiles & (Defir & ition 5 \\
\hline & Quan & tile & & stimate \\
\hline & $100 \%$ & Max & & 105.2262 \\
\hline & $99 \%$ & & & 105.2262 \\
\hline & $95 \%$ & & & 104.1927 \\
\hline & $90 \%$ & & & 01.1860 \\
\hline & $75 \%$ & Q3 & & 95.3839 \\
\hline & $50 \%$ & Median & & 89.5382 \\
\hline & $25 \%$ & Q1 & & 83.1486 \\
\hline & $10 \%$ & & & 72.8985 \\
\hline & $5 \%$ & & & 69.3063 \\
\hline & $1 \%$ & & & 63.3821 \\
\hline & $0 \%$ & & & 6 \\
\hline
\end{tabular}

Extreme Observations

$\begin{array}{crrr} & & & \\ \text { Value } & \text { Obs } & \text { Value } & \text { Obs } \\ 63.3821 & 3 & 99.3283 & 31 \\ 69.3063 & 6 & 101.1860 & 22 \\ 71.4711 & 12 & 103.2378 & 5 \\ 72.8985 & 33 & 104.1927 & 4 \\ 74.1621 & 30 & 105.2262 & 19\end{array}$




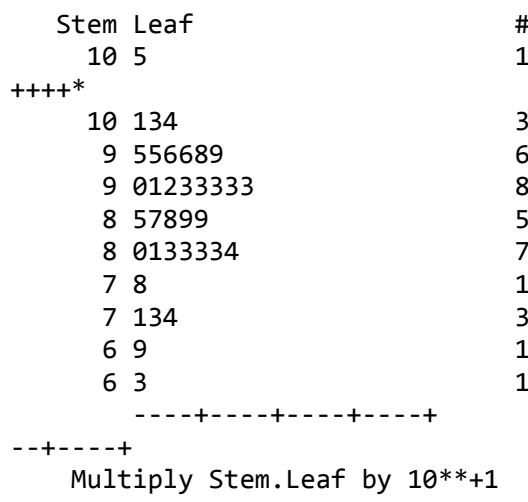

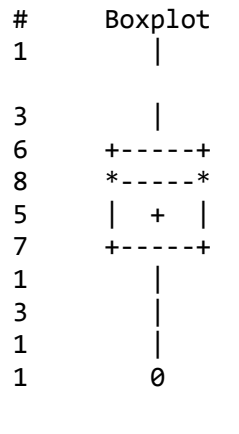

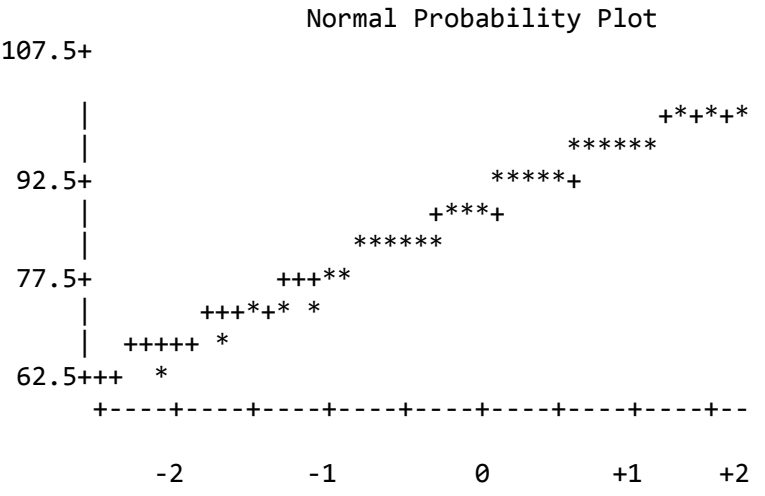

The Mixed Procedure

Model Information

Data Set

Dependent Variable

Covariance Structure

Estimation Method

Residual Variance Method

Fixed Effects SE Method

Degrees of Freedom Method

WORK.SET3

Response

Variance Components

REML

Profile

Model-Based

Containment

Class Level Information

Class

Levels Values

Day

Isolation

Heat

12234

Centrifuge Enzyme Filtration

high heat mild heat no heat

Dimensions

Covariance Parameters

Columns in $X$

Columns in $\mathrm{Z}$

Subjects

Max Obs Per Subject

3

16

16

Number of Observations

Number of Observations Read

Number of Observations Used

Number of Observations Not Used

36

36

Iteration History

$\begin{array}{rrrr}\text { Iteration } & \text { Evaluations } & -2 \text { Res Log Like } & \text { Criterion } \\ 0 & 1 & 192.42707005 & \\ 1 & 3 & 191.77950428 & 0.00017479 \\ 2 & 1 & 191.76587079 & 0.00000481 \\ 3 & 1 & 191.76552242 & 0.00000000\end{array}$


Convergence criteria met.

\section{Covariance Parameter Estimates}

$\begin{array}{lr}\text { Cov Parm } & \text { Estimate } \\ \text { Day } & 4.2210 \\ \begin{array}{l}\text { Day*Isolation } \\ \text { Residual }\end{array} & 0 \\ & 41.6996\end{array}$

Fit Statistics

$\begin{array}{ll}\text {-2 Res Log Likelihood } & 191.8 \\ \text { AIC (smaller is better) } & 195.8 \\ \text { AICC (smaller is better) } & 196.3 \\ \text { BIC (smaller is better) } & 194.5\end{array}$

Type 3 Tests of Fixed Effects

$\begin{array}{lrrrr}\text { Effect } & \begin{array}{r}\text { Num } \\ \text { DF }\end{array} & \begin{array}{r}\text { Den } \\ \text { DF }\end{array} & \text { F Value } & \operatorname{Pr}>\text { F } \\ \text { Isolation } & 2 & 6 & 3.39 & 0.1037 \\ \text { Heat } & 2 & 18 & 22.17 & <.0001 \\ \text { Isolation*Heat } & 4 & 18 & 1.09 & 0.3911\end{array}$

The Mixed Procedure

Least Squares Means

$\begin{array}{lllrrrrr}\text { Effect } & \text { Isolation } & \text { Heat } & \text { Estimate } & \begin{array}{r}\text { Standard } \\ \text { Error }\end{array} & \text { DF } & \text { t Value } & \operatorname{Pr}\rangle|t| \\ \text { Isolation } & \text { Centrifuge } & & & & & & \\ \text { Isolation } & \text { Enzyme } & & 84.7562 & 2.1284 & 6 & 39.82 & <.0001 \\ \text { Isolation } & \text { Filtration } & & 91.6148 & 2.1284 & 6 & 43.04 & <.0001 \\ \text { Heat } & & 88.2998 & 2.1284 & 6 & 41.49 & <.0001 \\ \text { Heat } & & \text { high heat } & 78.3610 & 2.1284 & 18 & 36.82 & <.0001 \\ \text { Heat } & & \text { mild heat } & 91.1368 & 2.1284 & 18 & 42.82 & <.0001 \\ \text { Isolation*Heat } & \text { Centrifuge } & \text { no heat } & 95.1731 & 2.1284 & 18 & 44.72 & <.0001 \\ \text { Isolation*Heat } & \text { Centrifuge } & \text { mild heat } & 71.8175 & 3.3882 & 18 & 21.20 & <.0001 \\ \text { Isolation*Heat } & \text { Centrifuge } & \text { no heat } & 87.9112 & 3.3882 & 18 & 25.95 & <.0001 \\ \text { Isolation*Heat } & \text { Enzyme } & \text { high heat } & 81.5399 & 3.3882 & 18 & 27.90 & <.0001 \\ \text { Isolation*Heat } & \text { Enzyme } & \text { mild heat } & 93.9852 & 3.3882 & 18 & 24.01 & <.0001 \\ \text { Isolation*Heat } & \text { Enzyme } & \text { no heat } & 99.5139 & 3.3882 & 18 & 27.74 & <.0001 \\ \text { Isolation*Heat } & \text { Filtration } & \text { high heat } & 81.9200 & 3.3882 & 18 & 29.37 & <.0001 \\ \text { Isolation*Heat } & \text { Filtration } & \text { mild heat } & 91.5139 & 3.3882 & 18 & 24.18 & <.0001 \\ \text { Isolation*Heat } & \text { Filtration } & \text { no heat } & 91.4656 & 3.3882 & 18 & 27.01 & <.0001 \\ & & & & & & <.0001\end{array}$


Differences of Least Squares Means

\begin{tabular}{|c|c|c|c|c|c|c|c|c|c|}
\hline \multirow[b]{2}{*}{ Effect } & \multirow[b]{2}{*}{ Isolation } & \multirow[b]{2}{*}{ Heat } & \multirow[b]{2}{*}{ Isolation } & \multicolumn{6}{|c|}{ Standard } \\
\hline & & & & Heat & Estimate & Error & DF & t Value & $\operatorname{Pr}>|t|$ \\
\hline Isolation & Centrifuge & & Enzyme & & -6.8586 & 2.6363 & 6 & -2.60 & 0.04 \\
\hline Isolation & Centrifuge & & Filtration & & -3.5436 & 2.6363 & 6 & -1.34 & 0.2275 \\
\hline Isolation & Enzyme & & Filtration & & 3.3150 & 2.6363 & 6 & 1.26 & 0.2553 \\
\hline Heat & & high heat & & mild heat & -12.7758 & 2.6363 & 18 & -4.85 & 0.0001 \\
\hline Heat & & high heat & & no heat & -16.8122 & 2.6363 & 18 & -6.38 & $<.0001$ \\
\hline Heat & & mild heat & & no heat & -4.0363 & 2.6363 & 18 & -1.53 & 0.1431 \\
\hline Isolation*Heat & Centrifuge & high heat & Centrifuge & mild heat & -16.0937 & 4.5662 & 18 & -3.52 & 0.0024 \\
\hline Isolation*Heat & Centrifuge & high heat & Centrifuge & no heat & -22.7224 & 4.5662 & 18 & -4.98 & $<.0001$ \\
\hline Isolation*Heat & Centrifuge & high heat & Enzyme & high heat & -9.5279 & 4.5662 & 18 & -2.09 & 0.0514 \\
\hline Isolation*Heat & Centrifuge & high heat & Enzyme & mild heat & -22.1677 & 4.5662 & 18 & -4.85 & 0.0001 \\
\hline on*Heat & Cent & high heat & Enzyme & to heat & -27.6964 & & & -6.07 & $<.0001$ \\
\hline${ }^{k}$ Heat & Cent & high heat & tion & high heat & -10.1025 & & 18 & -2.21 & .0401 \\
\hline${ }^{*}$ Heat & Centr & high heat & Filt & mild heat & -19.6964 & & 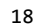 & -4.31 & 0.0004 \\
\hline Heat & Cent & high heat & tion & no heat & -19.6481 & & & -4.30 & 0.0004 \\
\hline Isola & Cen & mild heat & fuge & no & -6.6287 & & & -1.45 & 1638 \\
\hline Isolation*Heat & Centr & mild heat & Enzyme & high heat & 6.5658 & 4. & 18 & 1.44 & 0.1676 \\
\hline Isolation*Heat & Cent & mild heat & Enzi & mild heat & -6.0741 & & 18 & -1.33 & .2001 \\
\hline teat & Cent & mild heat & Enz & $o$ heat & -11.6027 & & & -2.54 & 0.0205 \\
\hline Isolatio & Cent & mild heat & ation & high heat & 5.9912 & 4.5 & 18 & 1.31 & .2060 \\
\hline Isol & Cen & mild heat & ion & mild heat & -3.6027 & & 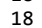 & -0.79 & 0.4404 \\
\hline eat & Cen & mild heat & tion & heat & 544 & & & -0.78 & 0.4464 \\
\hline Isolatio & Cent & no heat & Enzy & high heat & 13.1945 & 4.5662 & 18 & 2.89 & .0098 \\
\hline Isola & Cent & no heat & En>i & heat & 0.5547 & 4.5662 & 30 & .12 & 0.9047 \\
\hline Iso] & Cen & no heat & E & heat & -4. & 4. & & -1.09 & 0.2904 \\
\hline Isol & Cen & no heat & on & high heat & 12.6199 & 4.5 & 18 & 2.76 & 0.0128 \\
\hline Isolatic & Cent & no heat & Fil & mild heat & 3.0260 & 4.5 & 18 & 0.66 & 0.5159 \\
\hline Isolatio & Cent & no heat & ion & heat & 43 & & 10 & 0.67 & 0.5093 \\
\hline leat & Enz & high heat & $\mathrm{E}$ & mild heat & -12.6399 & 4 & 1 & -2.77 & 0.0127 \\
\hline Isolatio & Enzy & high heat & Enzy & no heat & -18.1685 & 4.5662 & 18 & -3.98 & 0.0009 \\
\hline Isola & Enz & high heat & cil & high heat & -0.5746 & 4.5 & 18 & -0.13 & 0.9013 \\
\hline Isol & Enz & high heat & ion & mild heat & -10.1685 & $45-5$ & & -2.23 & 0 a 030 \\
\hline Isol & Enz & high heat & tion & no heat & -10.1202 & 4.5 & 18 & -2.22 & 0.0398 \\
\hline on*Heat & Enzy & mild heat & Enzy & no he & -5.5286 & 4.5 & 18 & -1.21 & 0.2416 \\
\hline Heat & Enzy & mild heat & tion & high he & 12.0652 & & & 2.64 & 0.0166 \\
\hline Heat & Enzy & mild heat & tion & mild heat & 2.4713 & 4.5 & 18 & 0.54 & 0.5950 \\
\hline Isolation*Heat & Enzyme & mild heat & Filtration & no heat & 2.5196 & 4.5662 & 18 & 0.55 & 0.5879 \\
\hline Isolation*Heat & Enzyme & no heat & Filtration & high heat & 17.5939 & 4.5662 & 18 & 3.85 & 0.0012 \\
\hline Heat & & no heat & & & & & 18 & 1.75 & 0.0968 \\
\hline Isolation*Heat & Enzyme & no heat & Filt & no $h$ & 8.0483 & 4.5662 & 18 & 1.76 & 0.0949 \\
\hline Heat & Filtrat & high heat & tion & mild & -9.5939 & 4.5662 & 18 & -2.10 & 0.0500 \\
\hline Heat & Filtr & high heat & & no heat & & 4.5662 & 18 & -2.09 & \\
\hline Isolation*Heat & Filtration & mild heat & Filtration & no heat & 0.04830 & 4.5662 & 18 & 0.01 & 0.9917 \\
\hline
\end{tabular}

\section{Fisher Least Statistical Difference Test}

Native PAGE response to isolation method main effect:

$$
\begin{gathered}
L S D=t_{\alpha / 2}, N-a \sqrt{\frac{2 M S_{E}}{n}} \\
L S D=3.707 \sqrt{\frac{2(7816.63)}{2}} \\
L S D=28973.4
\end{gathered}
$$

Native PAGE response to heat treatment main effect:

$$
L S D=t_{\alpha / 2}, N-a \sqrt{\frac{2 M S_{E}}{n}}
$$




$$
\begin{gathered}
L S D=3.707 \sqrt{\frac{2(6619.89)}{2}} \\
L S D=24539.9
\end{gathered}
$$

pH 4.6 solubility measured by BCA response to isolation method main effect:

$$
\begin{gathered}
L S D=t_{\alpha / 2}, N-a \sqrt{\frac{2 M S_{E}}{n}} \\
L S D=3.707 \sqrt{\frac{2(2.6363)}{2}} \\
L S D=9.77
\end{gathered}
$$




\section{Appendix 2: Statistical Analysis for Experiment 2 (Minitab)}

\section{General Linear Model: \%Soluble @pH 4.6_1 versus Batch, Treatment}

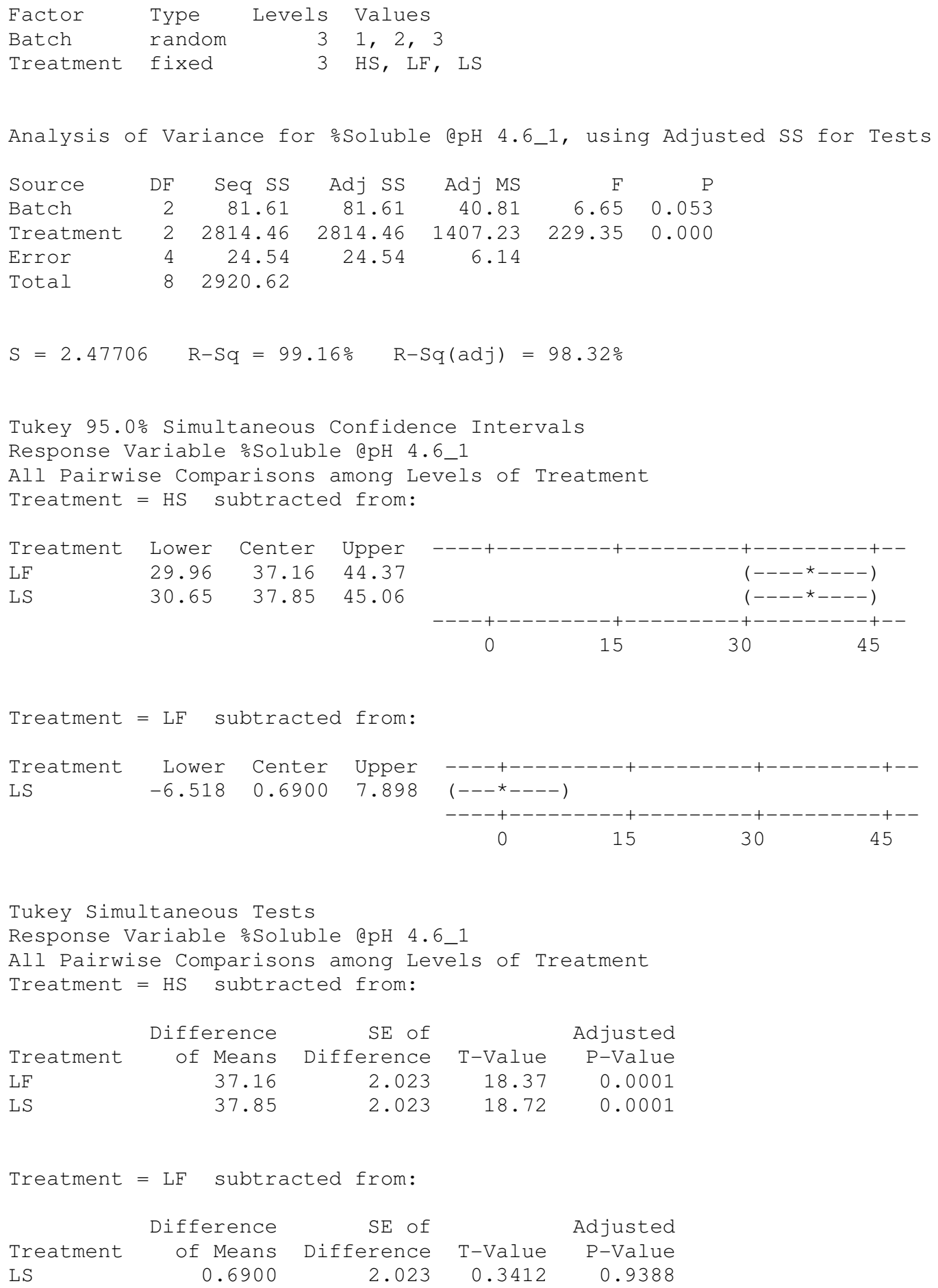




\section{General Linear Model: Peak Intenstity_1 versus Batch, Treatment_1}

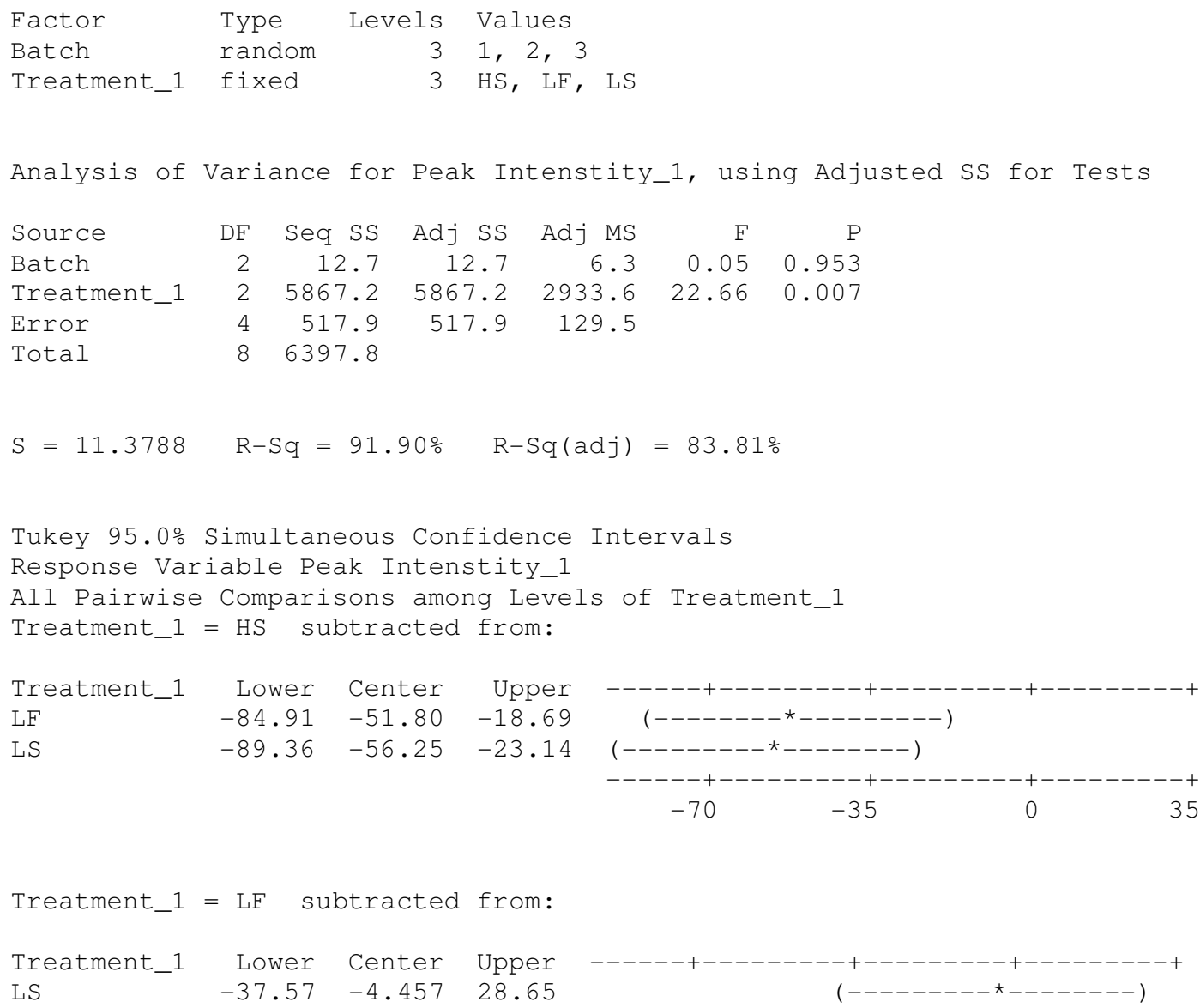

Tukey Simultaneous Tests

Response Variable Peak Intenstity_1

All Pairwise Comparisons among Levels of Treatment_1

Treatment_1 = HS subtracted from:

$\begin{array}{lrrrr} & \text { Difference } & \text { SE of } & \text { Adjusted } \\ \text { Treatment_1 } & \text { of Means } & \text { Difference } & \text { T-Value } & \text { P-Value } \\ \text { LF } & -51.80 & 9.291 & -5.575 & 0.0111 \\ \text { LS } & -56.25 & 9.291 & -6.055 & 0.0083\end{array}$

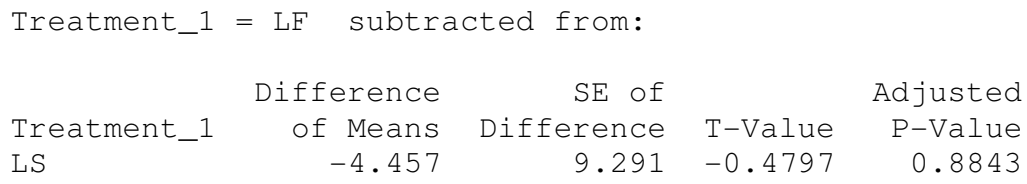


General Linear Model: Insolubility_1 versus Batch, Treatment_1

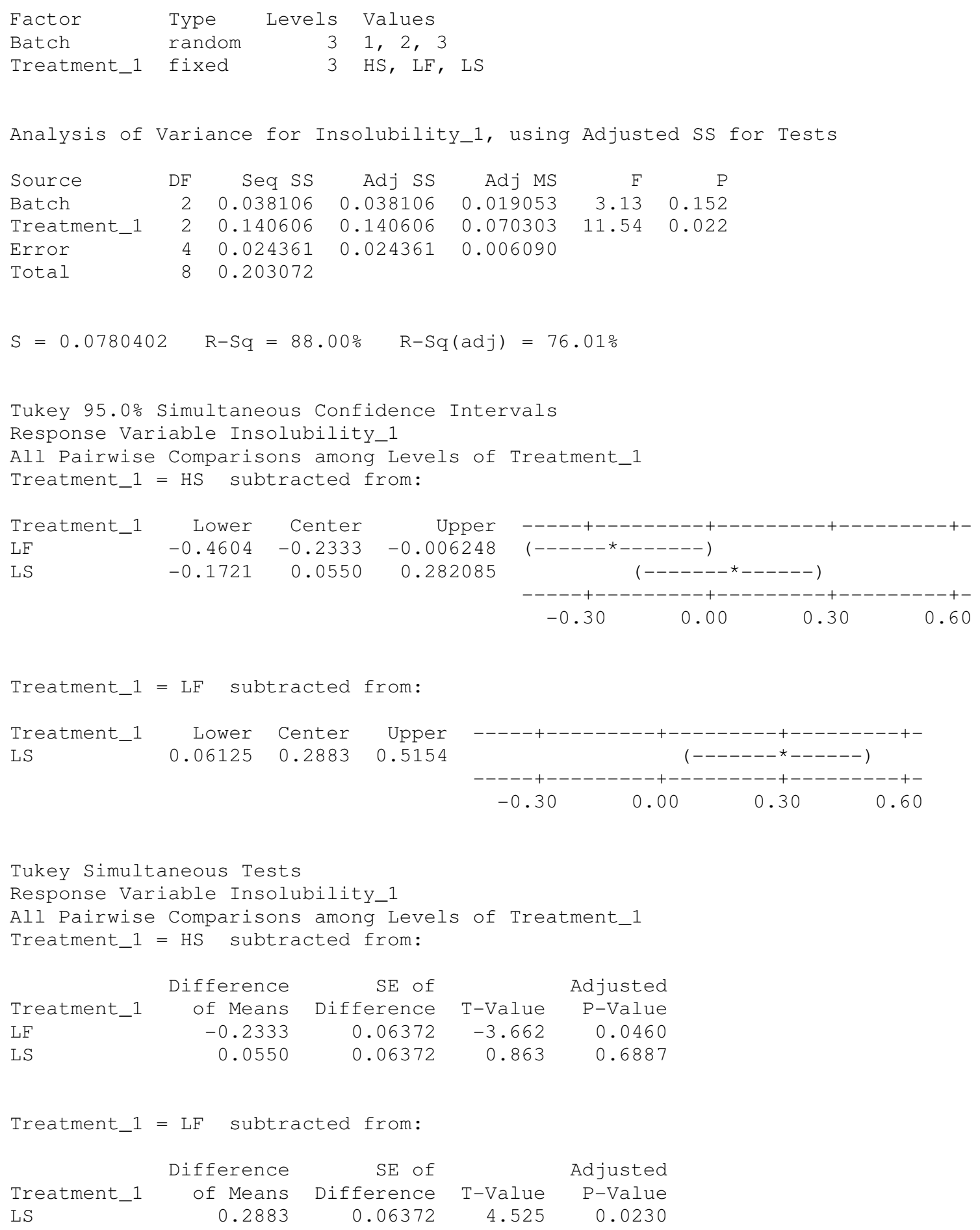




\section{$\underline{\text { Test Statistic for the F Distribution }}$}

$\mathrm{pH} 4.6$ solubility measured by BCA response to main effect treatment:

$$
F=229.35>F_{0.05,2,7}=4.74
$$

Fluorescence spectroscopy response to main effect treatment:

$$
F=22.66>F_{0.05,2,7}=4.34
$$

Functional solubility response to main effect treatment:

$$
F=11.54>F_{0.05,2,7}=4.34
$$

\section{Tukey's Test for Comparison of Treatment Means}

pH 4.6 solubility measured by BCA response to main effect treatment:

$$
\begin{gathered}
T_{\alpha}=q_{\alpha}(a, f) \sqrt{\frac{M S_{E}}{n}} \\
T_{\alpha}=5.0 \sqrt{\frac{6.14}{3}} \\
T_{\alpha}=7.153
\end{gathered}
$$

Fluorescence spectroscopy response to main effect treatment:

$$
\begin{gathered}
T_{\alpha}=q_{\alpha}(a, f) \sqrt{\frac{M S_{E}}{n}} \\
T_{\alpha}=5.0 \sqrt{\frac{129.5}{3}} \\
T_{\alpha}=32.85
\end{gathered}
$$


Functional solubility response to main effect treatment:

$$
\begin{gathered}
T_{\alpha}=q_{\alpha}(a, f) \sqrt{\frac{M S_{E}}{n}} \\
T_{\alpha}=5.0 \sqrt{\frac{0.0061}{3}} \\
T_{\alpha}=0.225
\end{gathered}
$$




\section{Appendix 3: Native PAGE Gels}
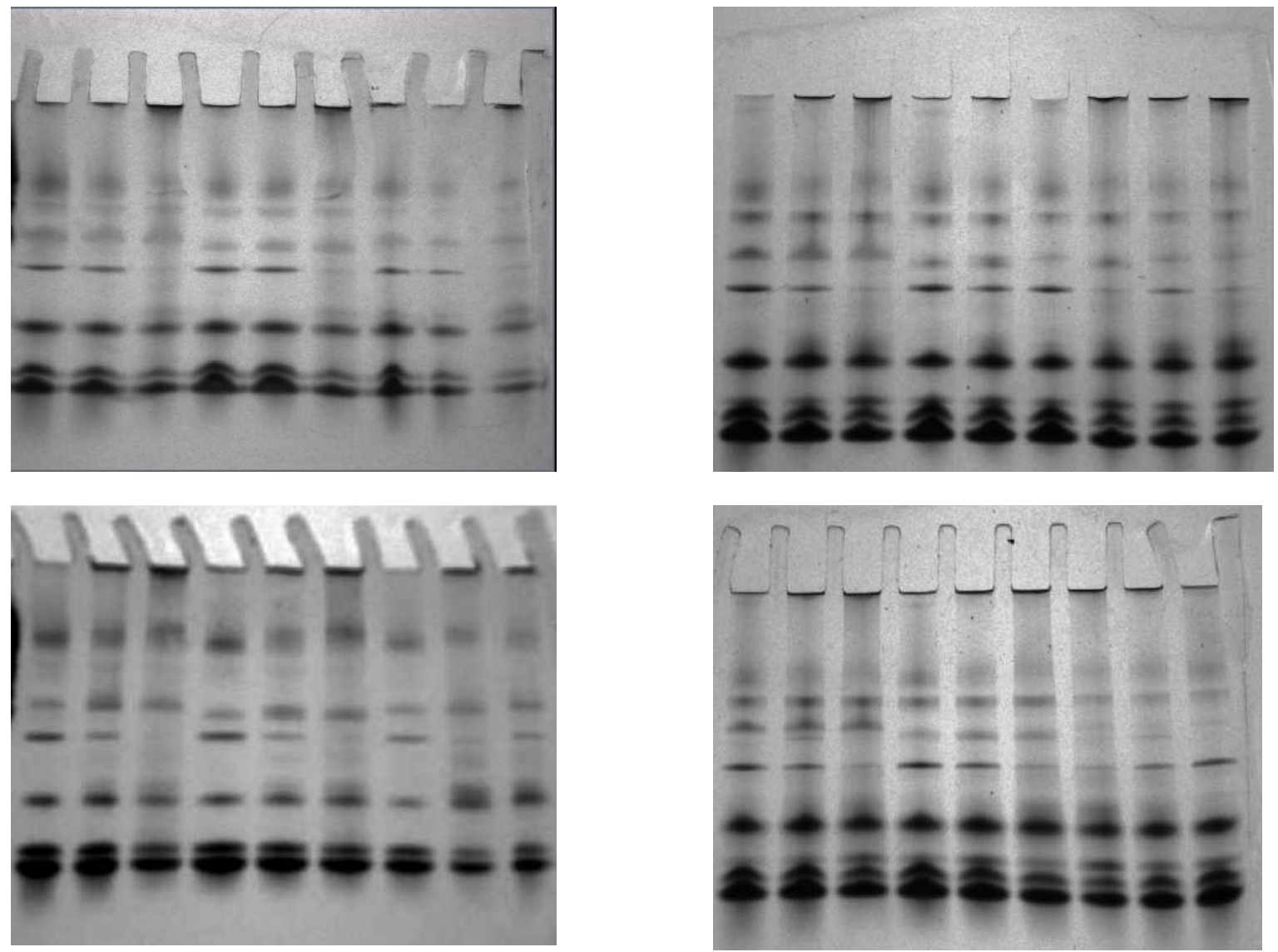

Key for all gels: From left to right- centrifugal force, no heat; centrifugal force, low heat; centrifugal force, high heat; enzyme isolation, no heat; enzyme isolation, low heat; enzyme isolation, high heat; membrane filtration, no heat; membrane filtration, low heat; membrane filtration, high heat 


\section{Appendix 4: List of Acronyms}

$\alpha$-helix: Alpha Helix

$\alpha$-la: Alpha-lactalbumin

ANOVA: Analysis of Variance

AAS: Amino Acid Score

$\beta$-lg: Beta-lactoglobulin

$\beta$-sheet: Beta-sheet

BCA: Bovine Serum Albumin

BSA-Bovine Serum Albumin

BV: Biological Value

CD: Circular Dichroism

CE: Capillary Electrophoresis

DPTC: Dairy Product Technology Center

FPLC: Fast Protein Liquid Chromatography

GLM: General Linear Model

FTIR: Fourier Transform-Infrared Spectroscopy

HPLC: High Pressure Liquid Chromatography

HTST: High Temperature, Short Time, Pasteurization

Ig: Immunoglobulin

LF:Lactoferrin

KN: Kjeldahl Nitrogen

MPa: Megapascal

NPU: Net Protein Utilization 
ODU: Optical Density Unit

PAGE: Polyacrylamide Gel Electrophoresis

PER: Protein Efficiency Ratio

PMO: Pasteurized Milk Ordinance

PP: Proteose Peptides

RP-HPLC: Reverse Phase-High Pressure Liquid Chromatography

SDS-PAGE: Sodium Dodecyl Polyacrylamide Electrophoresis

SE-HPLC: Size Exclusion-High pressure Liquid Chromatography

UHT: Ultra High Treatment

WPI: Whey Protein Isolate

WPN: Whey Protein Nitrogen 